\title{
Nutrition and Metabolism of Minerals in Fish
}

\author{
Santosh P. Lall ${ }^{1, *,+}$ and Sadasivam J. Kaushik $2,3, *$ (D) \\ 1 National Research Council of Canada, Halifax, NS B3H 3Z1, Canada \\ 2 Retd. INRA, 64310 St Pée sur Nivelle, France \\ 3 Ecoaqua Institute, Universidad de Las Palmas de Gran Canaria, 35214 Las Palmas, Spain \\ * Correspondence: santosh.lall13@gmail.com (S.P.L.); kjsachi@gmail.com (S.J.K.) \\ + Retired.
}

check for updates

Citation: Lall, S.P.; Kaushik, S.J. Nutrition and Metabolism of Minerals in Fish. Animals 2021, 11, 2711. https://doi.org/10.3390/ ani11092711

Academic Editors: Antony Prabhu and Johan W. Schrama

Received: 1 August 2021

Accepted: 13 September 2021

Published: 16 September 2021

Corrected: 9 December 2021

Publisher's Note: MDPI stays neutral with regard to jurisdictional claims in published maps and institutional affiliations.

Copyright: (c) 2021 by the authors. Licensee MDPI, Basel, Switzerland. This article is an open access article distributed under the terms and conditions of the Creative Commons Attribution (CC BY) license (https:// creativecommons.org/licenses/by/ $4.0 /)$.
Simple Summary: Our aim is to introduce the mineral nutrition of fish and explain the complexity of determining requirements for these elements, which are absorbed and excreted by the fish into the surrounding water. To date, only the requirements for nine minerals have been investigated. The review is focused on the absorption and the dietary factors that reduce their absorption from feed ingredients of plant and animal origin. Some diseases, such as cataracts, anemia and bone deformity, have been linked to dietary deficiency of minerals.

\begin{abstract}
Aquatic animals have unique physiological mechanisms to absorb and retain minerals from their diets and water. Research and development in the area of mineral nutrition of farmed fish and crustaceans have been relatively slow and major gaps exist in the knowledge of trace element requirements, physiological functions and bioavailability from feed ingredients. Quantitative dietary requirements have been reported for three macroelements (calcium, phosphorus and magnesium) and six trace minerals (zinc, iron, copper, manganese, iodine and selenium) for selected fish species. Mineral deficiency signs in fish include reduced bone mineralization, anorexia, lens cataracts (zinc), skeletal deformities (phosphorus, magnesium, zinc), fin erosion (copper, zinc), nephrocalcinosis (magnesium deficiency, selenium toxicity), thyroid hyperplasia (iodine), muscular dystrophy (selenium) and hypochromic microcytic anemia (iron). An excessive intake of minerals from either diet or gill uptake causes toxicity and therefore a fine balance between mineral deficiency and toxicity is vital for aquatic organisms to maintain their homeostasis, either through increased absorption or excretion. Release of minerals from uneaten or undigested feed and from urinary excretion can cause eutrophication of natural waters, which requires additional consideration in feed formulation. The current knowledge in mineral nutrition of fish is briefly reviewed.
\end{abstract}

Keywords: minerals; trace elements; fish; copper; iron; selenium; manganese; zinc; calcium; phosphorus; magnesium

\section{Introduction}

All aquatic animals require minerals for their vital physiological and biochemical functions and to maintain their normal life processes. Fish live in a wide range of salinity levels (0-35 0/00) in freshwater (FW), seawater (SW) and brackish water (BW) environments, and, unlike other vertebrates, absorb minerals from the diet as well as the surrounding water. Most of the essential minerals required for animals and other vertebrates [1] have been detected in fish tissues. The essentiality of macrominerals (calcium, phosphorus, magnesium, sodium, potassium and chloride) and certain trace elements (cobalt, copper, iodine, iron, manganese selenium and zinc) have been confirmed in fish [2,3]. Other trace elements (arsenic, boron, chromium, fluorine, nickel, lithium, lead, molybdenum, silicon and vanadium) considered essential for humans and animals based on the impairment of specific physiological functions have not been reported in fish. Mineral nutrition of fish has received limited attention as compared to other nutrients. The main focus of the 
current review is trace element nutrition and metabolism of fish with a brief discussion on major macrominerals. A significant amount of research has been directed towards the physiological aspects of waterborne mineral toxicity and is the subject of comprehensive reviews $[4,5]$.

The biochemical mechanisms of mineral metabolism in fish are generally considered similar to those of terrestrial animals at the cellular level. The exchange of ions from across the gills and skin of fish in surrounding water complicates the determination of the quantitative dietary requirement [6]. Gills comprise over 50\% of the surface area of the fish and are considered the major route of uptake of waterborne minerals in FW. In SW, fish exhibit obligatory drinking as part of their overall physiological osmoregulatory mechanism to maintain internal body fluids substantially hypotonic to the external salinity of seawater [7]. Therefore, absorption of dietary minerals from the gastrointestinal tract is important in FW fish, whereas in SW fish, both dietary and waterborne minerals are absorbed. The life cycle of anadromous fish like salmonids consists of FW and SW, where they gradually adapt to a marine environment and acquire inorganic elements by drinking SW, similar to marine fish.

In the past two decades, the number of farmed crustaceans, FW and marine fish species has increased considerably [8]. Often a generalization is made estimating their mineral requirements based on salmonids and certain freshwater species with proper consideration for the determination made on different types of diets (purified, semi-purified and practical diet) and the use of inorganic supplements with high bioavailability. In addition, fish feeds increasingly comprise alternate sources of plant-based feed ingredients as compared to previously widely used fish meal due to the increase in global aquaculture production and its limited supply. Obviously, there is a need to reassess the mineral requirements as well as their bioavailability from a wide range of plant feed ingredients as well as new alternate sources of feed ingredients compared to fish meal. The absorption of minerals may vary among fishes because of differences in gastric acid secretion in fish with stomach and agastric or stomachless fish [6] as well as uptake of minerals from water. There are also differences in the methodology used to measure the mineral requirements and response criteria (e.g., growth, feed utilization, whole body and/or vertebrae, plasma/serum and tissue mineral concentration, hematology and changes in specific enzyme activities).

Minerals are known to interact with other nutrients due to their lability and tendency to form chemical bonds. The term "interaction" for minerals was defined by O'Dell [9] as "interrelationships among mineral elements as revealed by physiological or biochemical consequences". Such interactions are broadly classified as positive or synergistic, or negative or antagonistic. Direct positive interactions between elements in structural processes such as the requirement of copper $(\mathrm{Cu})$ and iron $(\mathrm{Fe})$ for hemoglobin formation, calcium $(\mathrm{Ca})$, phosphorus $(\mathrm{P})$ and magnesium $(\mathrm{Mg})$ for formation of bone hydroxyapatite and an interaction of $\mathrm{Mn}$ with $\mathrm{Zn}$ for the proper conformational shape of RNA molecules in the liver have been widely recognized. Antagonistic relationships are considered to occur when trace elements with a similar electronic configuration and ionic radius compete for binding sites, such as zinc $(\mathrm{Zn})$ and cadmium $(\mathrm{Cd})$ in metallothionein, and $\mathrm{Mg} / \mathrm{manganese}$ (Mn) substitutions at active sites of enzymes. In the gastrointestinal tract, antagonistic relationships may occur by a simple mechanism, which involves a chemical reaction forming an insoluble complex between minerals such as $\mathrm{Cu}$ and sulfur (S) to form copper sulfide or a mineral and another dietary component such as $\mathrm{Zn}$ combined with phytic acid to form phytate [10]. A range of potential mineral-mineral and mineral-vitamin interactions have also been reported in fish [11]. Specific trace element interactions are discussed in appropriate individual sections.

Extensive research conducted on animals has clearly shown that mineral requirements are significantly affected by their bioavailability from different forms of feed supplements and feed ingredients. Bioavailability is defined as the proportion of dietary intake of an element that is utilized for biochemical or physiological functions [9]. Generally, the bioavailability reflects the absorption of the nutrient. From a practical standpoint, 
measurement of biochemical and physiological functions may not always be possible. Ammerman [12] suggested that more emphasis should be on the degree to which an ingested element could be utilized for metabolism. Limited information exists on the utilization and metabolism of trace elements in fish. The following methods have been used to determine the bioavailability of trace minerals in animals [9,12,13]: (a), growth, (b) apparent absorption or digestibility, (c) plasma or tissue mineral concentration, (d) mineral retention or balance, (e) specific enzyme activity (e.g., superoxide dismutase, glutathione peroxidase) or blood parameter (e.g., hemoglobin level), (f) prevention of deficiency signs. Some of these methods have also been used in fish to estimate the bioavailability of $\mathrm{Zn}, \mathrm{Fe}$ and selenium (Se) from chemically defined or practical diets based on fish meal and plant protein and are discussed later in individual sections.

Aquatic animals accumulate excessive minerals from water which can interact with as well as inhibit proteins that facilitate essential ion transport [14-16]. Metal binding reactions include competition at the biotic ligand with other cations (e.g., $\mathrm{Na}^{+}, \mathrm{H}^{+}, \mathrm{Ca}^{2+}$ ) and competing complexation reactions for the metal by other ligands in solution including inorganic anions (e.g., chloride, hydroxide, sulfide) as well as organic ligands such as dissolved organic carbon [16]. For example, accumulation of $\mathrm{Cu}$ at the fish gill interferes with $\mathrm{Na}^{+}$uptake, thereby disrupting ionic balance in the organism, leading to toxicity [17]. Similarly, Cd and Zn interfere with Ca uptake at the fish gill, leading to hypocalcemia and toxicity [18]. The ability of fish to regulate high concentrations of trace elements originating from water varies among different fish species. The major route of uptake for some metals, such as Se, mercury $(\mathrm{Hg})$ and arsenic (As), is trophic transfer through the food chain. Certain fish are able to excrete high proportions of excessive metal intake and consequently regulate the concentration in their body at relatively normal levels [19]. The soluble trace elements in water are considered more toxic than higher dietary intake of minerals such as $\mathrm{Cu}, \mathrm{Fe}$ and $\mathrm{Zn}$. The subject of aquatic toxicology to fish is beyond the scope of this review.

Minerals discharged from uneaten feeds, excretion of undigested material in feces and urine from hatcheries and aquaculture operations, directly influence the aquatic environment [20]. These minerals excreted in soluble and particulate forms affect water quality. The particulate form can settle to the bottom of ponds or tanks or accumulate at the end of raceways or in sediment under fish cages. The chemical composition of feedstuffs and type of inorganic or organic mineral supplements used have significant effects on the breakdown of organically bound minerals in feces and the amount of soluble inorganic compounds from urine in water. Microorganisms and several environmental factors (e.g., water current, temperature, dissolved oxygen levels, $\mathrm{pH}$ and salinity) and the type of microorganisms also affect minerals released from feces and urine in natural waters. Experimental studies have demonstrated that elevated concentrations of $\mathrm{Zn}$ and $\mathrm{Cu}$ originating from feeds in sediments under sea cages decrease to background levels after chemical remediation [21,22]. Some of these trace elements (e.g., $\mathrm{Cu}, \mathrm{Zn}, \mathrm{Cd}$, etc.) can also be associated with naturally occurring organic debris. Organic particles associated with metals are remobilized into the dissolved phase, and soluble $\mathrm{Cu}, \mathrm{Zn}$ and $\mathrm{Cd}$ form complexes with organic ligands in pore waters [23,24]. Fishery by-products and other ingredients may contribute to a minor amount of $\mathrm{Cd}$ in the finished feed. Cadmium can be scavenged from the water column and ultimately deposited with organic particles [25,26]. Several countries have developed legal measures to regulate the maximum limit of mineral supplementation in fish feeds to minimize their impacts on the environment.

The main purpose of this review is to update current knowledge of mineral nutrition of fish and to identify areas that require future research, particularly trace elements.

\section{Microminerals}

Optimum levels of essential macro- and microminerals are required for growth and maintenance of normal health of farmed fish. Four broad biochemical functions of microor trace elements are widely recognized: (a) catalytic, (b) structural, (c) physiological and (d) regulatory [27]. Trace minerals can act as catalysts in enzyme and endocrine systems, 
as integral and specific components of the structure of metalloenzymes and hormones or as activators (coenzymes) within those systems. More than one-third of all proteins require a trace element cofactor for normal function [28,29]. Numerous metalloenzymes are required for a wide range of metabolic activities such as energy production, protein digestion, cell replication and antioxidant activity, which are discussed in later sections. Deficiencies or suboptimum levels of the trace element may cause a decrease in or loss of enzyme activities [30]. Increased attention has been focused on certain micronutrients and immunostimulants to reduce susceptibility to various stressors and diseases, as well as enhance the overall health of humans, animals and fish [31-33]. The concept is based on understanding the contribution of minerals in reducing the detrimental effects of free radicals and toxic metabolites on immune processes in the animal's body. The knowledge in this area on the role of minerals in fish or shrimp as compared to animals and humans is scant.

\subsection{Copper}

It is widely accepted that $\mathrm{Cu}$ is an essential trace element required for cellular functioning of all living organisms. Copper ions have a unique chemistry due to their ability to adopt distinct redox states, either oxidized $\mathrm{Cu}^{2+}$ or the reduced state $\mathrm{Cu}^{3+}$. Due to the high avidity of biological ligands, free ionic $\mathrm{Cu}^{2+}$ is present in physiological fluids at extremely low concentrations. Copper metalloenzymes are involved in Fe metabolism, cellular energy production (cytochrome c oxidase), protection of cells from free radical damage (superoxide dismutase), collagen synthesis (lysyl oxidase) in brain neurotransmitters (dopamine hydroxylase and peptidyl alpha amidating monoxygenase) and melanin production (tyrosinase) [34]. Four Cu-containing enzymes, known as multi-copper oxidases (MCO) or ferroxidases, oxidize $\mathrm{Fe}^{2+}$ to $\mathrm{Fe}^{3+}$ ion, the form of iron that can be incorporated onto the protein transferrin for transport to the site of red blood cell formation. The MCO family comprises circulating and membrane-bound ceruloplasmin and two other proteins [35]. Metabolic changes in Cu-requiring proteins or alterations in enzyme activities may cause pathophysiological conditions [36].

Fish absorb $\mathrm{Cu}$ via the gills and digestive tract; however, the diet is considered a major source of $\mathrm{Cu}$ for growth, development and essential physiological functions [14,37]. The gill may contribute to a significant amount of $\mathrm{Cu}$ uptake depending upon the $\mathrm{Cu}$ concentration of the water [38], particularly when dietary $\mathrm{Cu}$ intake is low [39]. In rainbow trout fed a Cu-deficient diet, waterborne $\mathrm{Cu}$ uptake contributed the major proportion (60\%) of the body's $\mathrm{Cu}$; however, feeding high levels of $\mathrm{Cu}$ contributed to nearly $99 \%$ of body $\mathrm{Cu}$ [37]. Uptake of $\mathrm{Cu}$ from water and its toxicity have been extensively studied and reviewed $[17,40]$. Copper uptake is facilitated via two distinctive mechanisms: (a) by a transmembrane protein $(\mathrm{Cu}$ transporter 1$)$ and (b) the apical $\mathrm{Na}^{+}$uptake pathways located at branchial epithelial cells. The former pathway is insensitive to external $\mathrm{Cu}$ concentrations, and the latter pathway involving $\mathrm{Na}^{+}$uptake is sensitive to $\mathrm{Cu}$ [41]. In gastrointestinal $\mathrm{Cu}$ transport, apical $\mathrm{Cu}$ uptake appears to be passive while basolateral transport is active and rate limiting [42,43]. Copper is known to induce oxidative stress, olfactory impairment, increased plasma ammonia and disturbed acid-base balance [17,44]

Maintaining $\mathrm{Cu}$ homeostasis demands a critical physiological orchestration between $\mathrm{Cu}$ uptake and distribution within cells, and detoxification and removal. In fish and terrestrial vertebrates, the liver is the main organ involved in $\mathrm{Cu}$ homeostasis and metabolism [41,45]. Most studies on $\mathrm{Cu}$ homeostasis in fish have been undertaken in FW fish. After gill uptake and absorption from the gut, $\mathrm{Cu}$ is cleared from blood by the liver and incorporated into ceruloplasmin for transport to extrahepatic organs, stored in $\mathrm{Cu}$-protein complexes or excreted via the bile $[19,46]$.

\subsubsection{Requirement}

The dietary $\mathrm{Cu}$ requirement has been reported for several freshwater and marine fish (Table 1). These requirements are relatively low as compared to other trace elements. It 
is necessary to know the concentration of $\mathrm{Cu}$ in water, feed ingredients and tissue prior to requirement studies, in order to properly estimate the quantitative $\mathrm{Cu}$ requirement [1]. Copper in the water alone cannot meet the requirements so oral administration of $\mathrm{Cu}$ is essential for aquatic animals [3]. The dietary $\mathrm{Cu}$ requirement would depend on the physiological status of the animal, the concentration of $\mathrm{Cu}$ in the water and also the levels of elements that are metabolic antagonists of copper, such as Fe, $\mathrm{Zn}, \mathrm{Cd}$ and Mo [1,47]. A metaanalysis of published information on the $\mathrm{Cu}$ requirement of several fish species showed relatively close estimates for the $\mathrm{Cu}$ requirement $\left(\mathrm{mg} \mathrm{kg}^{-1}\right.$ diet) based on the following parameters: weight gain (WG), $[6,48]$ whole body, liver or vertebral $\mathrm{Cu}$ concentration $[6,48]$ and liver CuZn SOD (superoxide dismutase)) activity [6,48]. The antagonistic effects of Zn and $\mathrm{Cu}$ have not been observed in rainbow trout [49]. An interaction between dietary $\mathrm{Cu}$ and Se was observed in Atlantic salmon, where liver Se was inversely related to dietary $\mathrm{Cu}$ concentration [50].

Table 1. Iron and copper requirement of fish.

\begin{tabular}{|c|c|c|c|c|c|c|}
\hline \multirow[t]{2}{*}{ Fish Species } & \multicolumn{3}{|c|}{ Copper $^{a}$} & \multicolumn{3}{|c|}{ Iron $^{e}$} \\
\hline & $\mathrm{mg} \mathrm{kg}^{-1}$ & Main Response Criteria & Reference & $\mathrm{mg} \mathrm{kg}^{-1}$ & Main Response Criteria & Reference \\
\hline \multirow{2}{*}{ Atlantic salmon } & \multirow{2}{*}{$5-10$} & \multirow{2}{*}{ Liver $\mathrm{Cu}$} & \multirow{2}{*}[50]{} & $60-100$ & $\mathrm{H}^{\mathrm{f}}$, liver Fe & {$[51,52]$} \\
\hline & & & & 60 & $\begin{array}{l}\text { Weight gain, } \mathrm{H}^{\mathrm{f}} \text {, Liver } \\
\text { Fe }\end{array}$ & [52] \\
\hline Rainbow trout & 3 & Body, vertebral, liver $\mathrm{Cu}$ & [53] & & & \\
\hline Coho salmon & $5.1-5.5$ & WG, body, vertebrae $\mathrm{Cu}$ & {$[48]$} & & & \\
\hline Channel catfish & 5 & Liver $\mathrm{Cu}-\mathrm{Zn} \mathrm{SOD}$ & [54] & 30 & $W G, H^{f}$ & [55] \\
\hline Yellow catfish & $3.1-4.2$ & $\mathrm{WG}^{\mathrm{b}}, \mathrm{Cu}$ retention & [56] & 55.7 & & [57] \\
\hline Common carp & $3^{c}$ & Body, vertebral, liver $\mathrm{Cu}$ & [53] & 147.4 & Serum Fe & [58] \\
\hline Gibel carp & & & & 202 & Hematocrit, liver Fe & [59] \\
\hline Grass carp & $4.7-5$ & $\begin{array}{l}\text { WG, plasma ceruplasmin } \\
\text { activity }\end{array}$ & {$[60]$} & & & \\
\hline Hybrid tilapia & 4 & WG, body $\mathrm{Cu}$ retention & [61] & $\begin{array}{l}150-160^{g} \\
85^{\mathrm{e}}\end{array}$ & $\begin{array}{c}\text { Weight gain, } \\
\text { hemoglobin, liver Fe }\end{array}$ & [62] \\
\hline Japanese eel & & & & 170 & & {$[63]$} \\
\hline $\begin{array}{l}\text { Asian stinging } \\
\text { catfish }\end{array}$ & $5.2-5.7$ & $\begin{array}{l}\text { WG, plasma ceruplasmin } \\
\text { activity }\end{array}$ & [64] & & & \\
\hline Russian sturgeon & $7-8$ & $\begin{array}{l}\text { WG, whole body } \mathrm{Cu} \text {, liver } \\
\mathrm{Cu}-\mathrm{Zn} \text { SOD, serum } \\
\text { ceruloplasmin activity }\end{array}$ & [65] & & & \\
\hline Red sea bream & & & & 150 & & {$[66]$} \\
\hline Tongue sole & $11-12$ & $\begin{array}{l}\text { WG, serum Cu-Zn SOD } \\
\text { activity }\end{array}$ & [67] & & & \\
\hline Malabar grouper & $4-6$ & $\begin{array}{l}\text { WG, liver } \mathrm{Cu}-\mathrm{Zn} \mathrm{SOD} \\
\text { activity, body Cu retention }\end{array}$ & [68] & $100^{\mathrm{h}}$ & Liver Fe & [69] \\
\hline & $2-3^{d}$ & $\begin{array}{l}\text { WG, liver } \mathrm{Cu}-\mathrm{Zn} \text { SOD } \\
\text { activity, body Cu retention }\end{array}$ & [70] & & & \\
\hline Yellow croaker & $3.4-7$ & $\begin{array}{c}\text { Serum } \mathrm{Cu}-\mathrm{Zn} \text { SOD activity, } \\
\text { body and vertebral } \mathrm{Cu}\end{array}$ & [71] & & & \\
\hline Cobia & & & & $\begin{array}{l}80.5-94.7^{\text {e }} \\
71.3-75.1^{\text {i }}\end{array}$ & $\begin{array}{l}\text { WG, serum catalase } \\
\text { activity }\end{array}$ & [72] \\
\hline
\end{tabular}

${ }^{a}$ Unless specified, $\mathrm{CuSO}_{4} \cdot 5 \mathrm{H}_{2} \mathrm{O}$ used as $\mathrm{Cu}$ supplement; ${ }^{\mathrm{b}} \mathrm{WG}=$ weight gain; ${ }^{\mathrm{c}} \mathrm{CuCl}_{2}$ used as $\mathrm{Cu}$ supplement; ${ }^{\mathrm{d}}$ copper peptide used as $\mathrm{Cu}$ supplement; ${ }^{\mathrm{e}}$ unless specified, $\mathrm{FeSO}_{4} \cdot 6 \mathrm{H}_{2} \mathrm{O}$ used as $\mathrm{Fe}$ supplement; ${ }^{\mathrm{f}}$ hematology; ${ }^{\mathrm{g}}$ ferric citrate used as $\mathrm{Fe}$ supplement; ${ }^{\mathrm{h}}$ requirement for orange-spotted grouper (Epinephelus coioides); ${ }^{i}$ iron methionine used as Fe supplement.

\subsubsection{Deficiency}

Copper deficiency is well recognized in domestic animals [1]; however, gross deficiency signs of $\mathrm{Cu}$ have not yet been reported in fish. Unlike terrestrial vertebrates, small amounts of $\mathrm{Cu}$ are supplied by water as well as feeds. Therefore, overt deficiency signs would only occur during a long period of $\mathrm{Cu}$ deprivation. To date, the response criteria used to detect the $\mathrm{Cu}$ deficiency and adequacy of this element are not consistent, as shown in studies conducted on $14 \mathrm{FW}$ and marine fish species (Table 1). A decrease in growth, 
body and liver $\mathrm{Cu}$ concentration and ceruloplasmin and enzyme activities (liver $\mathrm{CuZn}$ SOD, heart cytochrome c oxidase) have been reported. In a long-term study, carp fed diets containing white fish meal without any supplementary $\mathrm{Cu}$ were found to exhibit reduced growth and cataract formation [73]. Other effects may include low pigmentation of the embryo, spinal cord deformation, cranial malformations, jaw underdevelopment, decreased length, increased time to complete yolk absorption, edema and opaque yolk sacs [74]. Low concentrations of waterborne $\mathrm{Cu}$ affected the hatching of fish eggs by inactivating chorionase activity, which causes osmotic disturbances and also affects the muscular movements necessary to break the eggshell $[74,75]$.

\subsubsection{Toxicity}

Generally, dietary $\mathrm{Cu}$ toxicity rarely occurs under practical feeding conditions except when there is an error in feed mixing or the use of $\mathrm{Cu}$-contaminated feed ingredients. Toxicity of $\mathrm{Cu}$ has been experimentally produced in rainbow trout, Atlantic salmon, rockfish (Sebastes schlegeli), Nile tilapia and African walking catfish (Clarias gariepinus), however, the tolerance of $\mathrm{Cu}$ varies among fish species [76-86]. Signs of oral $\mathrm{Cu}$ toxicity include reduced growth and feed utilization, changes in hematological parameters and tissue lipid peroxidation. Dietary copper toxicity measured as growth inhibition in rainbow trout was approximately $664-730 \mathrm{mg} \mathrm{Cu} \mathrm{kg}^{-1}$ feed corresponding to $44 \mathrm{mg} \mathrm{Cu} \mathrm{kg}^{-1}$ body weight per day $[76,80]$. Much lower concentrations of $\mathrm{Cu}\left(34 \mathrm{mg} \mathrm{kg}^{-1}\right)$ in Atlantic salmon diet caused tissue lipid peroxidation [87]. The estimated threshold of diet-borne $\mathrm{Cu}$ toxicity for Atlantic salmon parr and fry, based on organ copper burden and reduced growth, ranged from 15 to $17 \mathrm{mg} \mathrm{Cu} \mathrm{kg}^{-1}$ per day [80]. The EU Commission-authorized maximum content of $\mathrm{Cu}$ in complete feed for salmonids and other fish species is $25 \mathrm{mg} \mathrm{kg}^{-1}$ [88].

Aquatic $\mathrm{Cu}$ toxicity in fish and other organisms has been the subject of extensive research for five decades [17] and is briefly mentioned in this section. The mechanism of $\mathrm{Cu}$ toxicity differs in FW and SW. In FW, Cu toxicity varies with water hardness, $\mathrm{pH}$, anions and dissolved organic carbon. Copper toxicity is more lethal in soft compared to hard waters rich in cations (e.g., $\mathrm{Ca}^{2+}$ and $\mathrm{Mg}^{2+}$ ) as cations reduce bioavailability of $\mathrm{Cu}$ and thus accentuate toxic effects [89]. Copper is more toxic under acidic conditions $(\mathrm{pH}<6)$. Anions and dissolved organic carbon bind to $\mathrm{Cu}$ and form compounds, thus reducing the toxic effects [90]. In SW, waterborne Cu toxicity affects not only gills but also the intestine because marine fish drink to compensate for water loss into the surrounding water. The cause of reduced oxidative metabolism appears to be gill damage, manifested as either disruption of branchial structure, secretion of mucus that binds metals and impedes the rates of diffusion, inhibition of respiratory enzymes and damage to gill oxygen receptors [17]. In addition to gills, $\mathrm{Cu}$ toxicity also affects the liver, kidney, heart, brain and reproductive organs. In summary, exposure to higher levels of $\mathrm{Cu}$ in water affects several physiological and biochemical functions, affecting the performance of the whole organism by decreasing metabolic rate and causing oxidative stress [40,91]. Oxidative damage from $\mathrm{Cu}$ exposure has been observed as changes in biomarkers (e.g., protein carbonyls, lipid peroxidation and DNA damage products) in the gill, liver and intestine of numerous fish species [40].

\subsubsection{Bioavailability}

Limited information exists on the availability of $\mathrm{Cu}$ from feed ingredients or $\mathrm{Cu}$ feed additives. Feed ingredients of plant and animal sources show a variable $\mathrm{Cu}$ content resulting from either contaminants originating from soil or during the processing of plant and animal products. Common $\mathrm{Cu}$ feed additives commercially available to supplement fish and animal feeds are copper sulfate; cupric chloride; cupric carbonate; cupric acetate; cupric methionate; cupric oxide; cupric chelate of amino acid hydrate; copper lysine sulfate; cupric chelate of glycine hydrate; copper chelate of hydroxy analogue of methionine; dicopper chloride trihydroxide and copper bislysinate. In most fish studies, copper sulfate has been used as a dietary supplement or a standard for the evaluation of $\mathrm{Cu}$ bioavailability. To date, limited research effort has been made to measure the bioavailability of $\mathrm{Cu}$ from 
inorganic and organic forms or the residual $\mathrm{Cu}$ present in feed ingredients. Some studies dealing with the inclusion of different forms of trace elements such as Zn, Mn and Se in plant protein-rich diets suggest that dietary minerals supplemented in the organic form could be reasonably considered more effective than the inorganic and encapsulated forms of supply [92]. A wide range of methods (e.g., plasma/liver Cu, erythrocyte SOD activity, plasma ceruloplasmin and bile $\mathrm{Cu}$ ) have been used to estimate $\mathrm{Cu}$ bioavailability in animals [13].

Studies conducted on bioavailability from different organic $\mathrm{Cu}$ sources in animal feeds show similar bioavailability while others show higher bioavailability relative to copper sulfate NRC [47]. Some of the differences have been attributed to species differences, age of animals, response criteria and the method used. In rainbow trout fed semi-purified diets, cupric sulfate $\mathrm{Cu}$-proteinate and $\mathrm{Cu}$-lysine showed similar bioavailability [93]. Cu-Met and nano-copper oxide were also shown to be more bioavailable than copper sulfate in Russian sturgeon [65]. Metal ion interactions with $\mathrm{Cu}-\mathrm{Zn}$ have been observed in higher animals [94], but no significant antagonism between $\mathrm{Cu}$ and $\mathrm{Zn}$ was observed in rainbow trout fed plant-based diets [95].

\subsection{Iron}

Iron is one of the most investigated essential trace elements, and is present in all body cells of vertebrates $[3,96]$. It is essential for the functioning of several biochemical processes, which include the electron transfer reaction, gene regulation, binding and transport of oxygen and regulation of cell growth and differentiation. The most important Fe-containing compounds are the heme proteins, hemoglobin, myoglobin and cytochromes. Enzymes containing non-heme Fe such as iron-sulfur cluster proteins (e.g., nicotinamide adenine dinucleotide (NADH) dehydrogenase, succinate dehydrogenase, xanthine oxidase) are involved in energy metabolism. Another group of Fe-containing enzymes (e.g., hydrogen peroxidases) are well known to act on reactive molecules originating as the by-products of oxygen metabolism. The formation of the reduced form of iron, $\mathrm{Fe}^{2+}$, can produce highly reactive hydroxyl and lipid radicals, which can damage lipid membranes, nucleic acids and proteins. In mammals, iron homeostasis involves the regulation of its absorption into the body, regulation of iron entry into cells, the incorporation of iron into proteins, the storage of iron in ferritin and the regulation of iron released for transport to other cells and organs.

Although there is relatively little information on absorption and metabolism of iron in fish, some studies suggest that mechanisms of iron absorption from the digestive tract and storage and excretion may be similar to those in other vertebrates [14,97]. It is widely recognized that Fe metabolism involves its absorption from the gastrointestinal tract into the body, entry into cells, the incorporation into proteins and the storage of Fe in ferritin in different tissues. Although fish gills play an important role in Fe acquisition, the uptake is relatively low $[98,99]$. Like other trace elements, the gastrointestinal tract is considered the major route of Fe absorption [100]. The uptake of Fe from natural waters is considered low. Fish gills play an important role in Fe acquisition [101], particularly in developing fish when the digestive tract is not fully functional [98]. The gastrointestinal tract is considered the major site of Fe absorption [99]. In the acidic environment of the stomach, ferric ion is released from the ingested food materials and binds to mucin which may facilitate metal solubility in the small intestine of fish [100]. It is proposed that epithelial mucus secretion may play an important role in maintaining metal solubility in fish $[102,103]$. The mechanism of Fe absorption in marine fish is not clear. They ingest significant amounts of $\mathrm{Ca}$ and $\mathrm{Mg}$ from SW and also secrete large quantities of bicarbonate [104] that could potentially cause problems for intestinal iron uptake. It has been suggested that metalmucus chelates that retain the metal in solution in the intestinal tract, reducing agents in foods (e.g., ascorbic acid) and other physiological factors in the gut may modify $\mathrm{Fe}$ solubility and enhance its absorption [14,98]. Food is regarded as the main source of Fe for metabolic purposes [14,98]. A small amount of Fe is eliminated via the liver (i.e., bile) and to some extent by the kidney [102]. 


\subsubsection{Requirement}

The Fe requirement reported for certain fish species (Table 1) ranges from $30-170 \mathrm{mg} \mathrm{kg}^{-1}$ diet with the exception of gibel carp which has a reported optimum requirement value of $202 \mathrm{mg}$ $\mathrm{kg}^{-1}$ diet. Response criteria used to estimate Fe requirements were weight gain, whole body, liver and plasma iron concentration and hematological parameters (hemoglobin, hematocrit, mean corpuscular volume, mean corpuscular hemoglobin). A meta-analysis of published information on $\mathrm{Fe}$ requirements of several fish species showed estimates for Fe requirements ranging from $58.8-166.4 \mathrm{mg} \mathrm{kg}^{-1}$ with a wide variation for all parameters tested [105]. It should be emphasized that weight gain alone may not provide a good estimate of Fe requirement. Most of the Fe body pool is in the form of hemoglobin in red blood cells. At later stages of growth and maturity, the Fe requirement is likely to change as the blood volume declines and a lower rate of iron deposition occurs in tissues [1].

\subsubsection{Deficiency and Toxicity}

Generally Fe deficiency causes anemia and tissue Fe depletion in fish and other vertebrates [30]. A characteristic microcytic anemia has been detected in brook trout [106,107], rainbow trout [107], Atlantic salmon [51,108], red sea bream [109,110], yellowtail [110], eels [63] and carp [66] fed low-iron diets. In most cases, semi-purified diet without Fe supplementation did not affect the growth of fish, except cobia, where fish fed a basal diet without Fe supplement $\left(45.8 \mathrm{mg} \mathrm{kg}^{-1}\right)$ showed a decrease in weight gain and feed efficiency [72]. In addition, a decrease in $\mathrm{Hb}$ and serum catalase activity was also observed. In catfish, Fe deficiency suppressed hematocrit, hemoglobin and plasma iron levels and caused transferrin saturation [55].

Effects of Fe toxicity in fish and animals have been comprehensively reviewed [102] and are briefly mentioned in this section. Dietary Fe toxicity was experimentally produced in rainbow trout fed levels higher than $1380 \mathrm{mg} \mathrm{Fe} \mathrm{kg}^{-1}$ [107], a concentration far above the level found in ingredients used to formulate either practical or purified diets. The major effects of Fe toxicity were reduced growth, poor feed utilization, feed refusal, increased mortality, diarrhea and histopathological damage to liver cells. Iron toxicity occurs from excessive Fe exposure of fish in water, which interferes with Fe homeostatic regulation by causing Fe overload in tissues [102]. Iron naturally exists as soluble ferrous $\left(\mathrm{Fe}^{2+}\right)$ and insoluble ferric particulate iron $\left(\mathrm{Fe}^{3+}\right)$. In oxygenated waters, soluble $\mathrm{Fe}^{2+}$ oxidizes to $\mathrm{Fe}^{3+}$ and in circumneutral waters $(\mathrm{pH}>6.5), \mathrm{Fe}^{3+}$ ions are insoluble and rapidly precipitate as hydroxides and oxyhydroxides. Iron toxicity in water is closely related to Fe speciation and the interaction of Fe with body and gill surfaces. Excess Fe in the water is known to cause respiratory disruption due to physical clogging of the gills [111].

\subsubsection{Bioavailability}

Iron in feeds is in two forms, heme iron and non-heme iron. Feed ingredients of animal origin (e.g., fish meal, animal meat and blood meal) are the major sources of heme iron. Non-heme iron refers to other sources of iron within feeds or inorganic contaminants from ingredient and/or feed processing. In cereal grains, a small proportion of $\mathrm{Fe}$ may be present as an iron phytin complex. Several factors are known to affect Fe absorption, including the amount and chemical form of Fe, Fe status and age of the animal, physiological conditions of the gastrointestinal tract (e.g., $\mathrm{pH}$ ) and other dietary components (e.g., phytic acid, ascorbic acid, citrate) [112]. In juvenile animals, growth, hemoglobin concentration, plasma Fe and its retention may respond linearly to Fe supplementation; however, Fe repletion in deficient animals is considered the preferred method to estimate iron bioavailability [13].

Little is known about the bioavailability of Fe from feed ingredients and inorganic/organic iron feed supplements for fish. Bioavailabilities of ferrous sulfate and ferric chloride are considered to be essentially the same [6]. In red sea bream, ferrous and ferric chloride were more efficiently utilized than ferric citrate [113]. The biological availability of Fe measured by a hemoglobin regeneration assay in Atlantic salmon showed that the relative availability of $\mathrm{Fe}$ from ferric chloride, ferric oxide, blood meal and herring meal was 98.8, 17.8, 52.3 and 47.1\%, respectively [52]. However, higher bioavailabilities of iron from blood meal [98], Fe-hydroxy 
methionine analogue [114] and Fe-methionine [72] have been reported for Atlantic salmon, grouper and cobia, respectively. The quality of blood meal varies widely in terms of protein quality. Whether the wide range of temperature and processing conditions used to produce blood meal affects the bioavailability of Fe remains to be investigated. There is also a need to standardize the method to predict the bioavailability of Fe in fish diets.

\subsection{Manganese}

Manganese plays an important role in protein and energy metabolism, bone mineralization, glycosaminoglycan synthesis, cellular defense against free radicals and metabolic regulation [115]. The essentiality of $\mathrm{Mn}$ in the above biochemical processes is based on its function as an enzyme activator (e.g., oxidoreductases, lyases, ligases, hydrolases, kinases, decarboxylases) and constituent of several metalloenzymes [116]. Many enzymes activated by $\mathrm{Mn}$ can be also activated by other metals, particularly $\mathrm{Mg}$, with the exception of glutamine synthetase, glycosyltransferases, farnesyl pyrophosphate synthetase and phosphoenolpyruvate carboxykinase, which show specific Mn activation. Manganese metalloenzymes include arginase, pyruvate carboxylase and Mn superoxide dismutase (MnSOD). Limited information exists on the physiological aspects of Mn uptake from both gills and intestine and its metabolism in fish. In mammals, gastrointestinal absorption and biliary elimination of $\mathrm{Mn}$ are the two main regulatory sites of Mn homeostasis, which are influenced by the dietary Mn intake [115,117]. Excretion of Mn in bile and feces has also been observed in Atlantic salmon [118]. Manganese and Fe compete for absorption sites. A small fraction of biliary Mn excreted into the intestine may be reabsorbed. Manganese is efficiently absorbed from the diet but the absorption may be reduced by high levels of $\mathrm{Ca}$ and $\mathrm{P}$, fiber and phytate [6]. Divalent Mn entering the circulation system is removed rapidly by the liver. Reduced intestinal absorption, enhanced liver metabolism and increased biliary excretion are considered adaptive mechanisms during high dietary intake of Mn [115].

Manganese uptake from FW has been demonstrated from the gills and gastrointestinal tract $[119,120]$. Unlike other trace metals, the mechanisms of Mn uptake from the gills, gut, skin and other tissues and toxicity are poorly understood. Brown trout exposed to low concentrations of $\mathrm{Mn}$ readily accumulated this metal in the blood and other tissues (gills, epidermal mucus, liver, kidney, viscera, skeleton and brain) [120]. The Mn toxicity was affected by water hardness and low $\mathrm{pH}$ and a higher risk of Mn toxicity to fish has been observed in acidic and Ca-deficient water [120,121]. These conditions can markedly enhance the uptake and toxicity of $\mathrm{Mn}$ and other metals. High concentrations of Mn caused $\mathrm{Na}$ imbalance, reduced the absorption of $\mathrm{Ca}$ and $\mathrm{P}$, affected carbohydrate metabolism and impaired the immune functions of fish $[122,123]$. They also caused oxidative stress, tissue damage, inflammation, neurodegeneration and disruption of homeostasis of other metals in fish $[120,124]$.

\subsubsection{Requirement}

Manganese requirements of fish range from 2.5 to $25 \mathrm{mg} \mathrm{kg}^{-1}$ diet (Table 2). Some of these differences are likely due to differences in Mn uptake in water and bioavailability of $\mathrm{Mn}$ in experimental diets. Different requirement values were found using three different forms of Mn additives for cobia: manganese sulfate, 15.4; Mn-glycine, 11.2; Mn-2-hydroxy4-(methylthio) butyrate, $10.5 \mathrm{mg} \mathrm{Mn} \mathrm{kg}^{-1}$ [125]. In addition to growth, several studies have shown that body and vertebral $\mathrm{Zn}$ provides a good estimate of Mn requirements. A meta-analysis of Mn requirements for several fish species estimated 10.7, 13.4 and $18.4 \mathrm{mg}$ $\mathrm{Mn} \mathrm{kg}^{-1}$ for weight gain, whole body Mn and vertebral Mn content, respectively [105]. It appears that broodstock fish require larger amounts of Mn than juvenile fish [126]. Other dietary (e.g., Ca, P, phytate) and physiological factors, particularly changes occurring in bone mineralization at various stages of development, should also be taken into account for the estimation of $\mathrm{Mn}$ requirements of fish [6]. 
Table 2. Manganese requirements of certain fish ${ }^{\mathrm{a}}$.

\begin{tabular}{|c|c|c|c|}
\hline Fish Species & $\mathrm{mg} \mathrm{kg}^{-1}$ & Main Response Criteria & Reference \\
\hline \multirow{2}{*}{ Atlantic salmon } & 15 & Body and vertebral Mn & [127] \\
\hline & $7.5-10.5$ & Body Mn & [128] \\
\hline Rainbow trout & $12-13$ & $W^{b}$ & [53] \\
\hline Channel catfish & 2.4 & WG & [129] \\
\hline Yellow catfish & $5.5-6.4$ & WG, vertebral Mn, liver Mn-SOD ${ }^{c}$ & [130] \\
\hline Common carp & $12-13$ & Growth rate & [53] \\
\hline Gibel carp & 13.8 & WG, body and vertebral Mn & [131] \\
\hline Hybrid tilapia & 7 & Body Mn, liver Mn-SOD & [132] \\
\hline Grouper $^{\mathrm{d}}$ & 15 & Body and vertebral $\mathrm{Mn}$ & [123] \\
\hline Yellow croaker & 16.4 & Growth rate, liver Mn-SOD & [133] \\
\hline \multirow{2}{*}{ Cobia } & $21.7-24.9$ & WG, body and vertebral Mn & [134] \\
\hline & $10.5-15.4^{\mathrm{e}}$ & Specific growth rate, liver Mn-SOD & [125] \\
\hline
\end{tabular}

a Unless specified, $\mathrm{MnSO}_{4} \cdot \mathrm{H}_{2} \mathrm{O}$ used as $\mathrm{Mn}$ supplement; ${ }^{\mathrm{b}}$ weight gain; ${ }^{\mathrm{c}}$ liver Mn-SOD activity; ${ }^{\mathrm{d}}$ orange spotted grouper (Epinephelus coiodes); ${ }^{\mathrm{e}} \mathrm{MnSO}_{4} \cdot \mathrm{H}_{2} \mathrm{O}$, manganese glycine and manganese 2-hydroxy-4(methylthio)butyrate showed $\mathrm{Mn}$ requirements of $15.4,11.2$ and $10.5 \mathrm{mg} \mathrm{kg}^{-1}$, respectively.

\subsubsection{Deficiency}

The deficiency signs of Mn have been experimentally produced in several fish species. In addition to reduced growth, Mn deficiency causes skeletal abnormalities in rainbow trout, carp and tilapia $[53,135,136]$. In studies designed to determine Mn requirements of certain fish species (Table 2), a low intake of Mn caused reduced body and/or vertebral Mn concentration, a sign of poor bone mineralization. Although Mn deficiencies have been shown to cause a decrease in the activity of several enzymes in mammals [115], to date, decreases in the activity of liver Mn-SOD activity have been reported in Atlantic salmon [128], tilapia [132], cobia [125], gibel carp [131] and yellow catfish [130]. Low levels of dietary Mn (2.4 $\left.\mathrm{mg} \mathrm{kg}^{-1}\right)$ did not affect Mn-SOD activity in catfish [129]. A decrease in cardiac muscle $\mathrm{Cu}-\mathrm{Zn}$-SOD was also observed in rainbow trout fed Mn-deficient diet [137]. Mn deficiency in broodstock rainbow trout diets affected reproductive performance and caused poor hatchability of eggs [126]. Manganese is considered to be one of the least toxic of the essential trace elements. However, high concentrations of dietary Mn supplementation $\left(1 \mathrm{~g} \mathrm{~kg}^{-1}\right)$ caused changes in feeding behavior, a decrease in body Fe concentration and elevation in $\mathrm{Zn}$ concentration in the body and vertebrae of grouper [123]. Freshwaterborne $\mathrm{Mn}$ toxicity in brown trout caused histological changes in their olfactory nerve and brain [120]. The effects of dietary Mn toxicity on the olfactory system and brain function of humans and animals are well documented [138].

\subsubsection{Bioavailability}

Dietary Mn absorbed from the gastrointestinal tract is generally low in monogastric animals [13]. Several manganese compounds are available for use in animal/fish feeds: manganous chloride $\left(\mathrm{MnCl}_{2} \cdot 4 \mathrm{H}_{2} \mathrm{O}\right)$, manganous oxide $(\mathrm{MnO})$, manganous sulfate $\left(\mathrm{MnSO}_{4} \cdot 4 \mathrm{H}_{2} \mathrm{O}\right.$ or $\left.\mathrm{MnSO}_{4} \cdot \mathrm{H}_{2} \mathrm{O}\right)$, manganese carbonate $\left(\mathrm{MnCO}_{3}\right)$, manganese acetate, manganous hydrogen phosphate $\left(\mathrm{MnHPO}_{4} \cdot 3 \mathrm{H}_{2} \mathrm{O}\right)$, manganese amino acid complex, manganese methionine complex, manganese amino acid chelate and manganese proteinate. However, the availability of only a few compounds has been tested and their availability may differ in various inorganic Mn salt supplements. Manganese in manganous oxide is poorly utilized by rainbow trout and Atlantic salmon $[6,139]$. The most commonly used source of $\mathrm{Mn}$ in fish feeds is manganous sulfate, monohydrate. The availability of $\mathrm{Mn}$ is low in manganous carbonate for carp [140]. Mn-glycine was effectively utilized by cobia, turbot and Atlantic salmon reared in SW [118,125,141]. Mn-glycine was better utilized by cobia and turbot than manganous sulfate $[125,141]$. The availabilities of Mn-methionine and 
Mn-2-hydroxy-4-(methylthio) butyrate were relatively high for turbot [141] and cobia [125], respectively. Phytic acid, like other divalent ions $\left(\mathrm{Zn}^{2+}, \mathrm{Cu}^{2+}\right.$ and $\left.\mathrm{Fe}^{2+}\right)$, binds inorganic $\mathrm{Mn}$ and reduces its bioavailability [142]. Recently, Antony Jesu Prabhu et al. [118,143] found that dietary supplementation of $15 \mathrm{mg} \mathrm{kg}^{-1}$ of Mn-Gly lowered the digestibility of $\mathrm{Zn}$ and $\mathrm{Cu}$. The environmental impact of undigested Mn excretion in natural water is widely recognized so the upper limit has been set for $\mathrm{Mn}$ in complete feeds in certain countries. In Europe, the maximum limit for fish feed is $100 \mathrm{mg} \mathrm{kg}^{-1}$ [144].

\subsection{Selenium}

Selenium as an essential micronutrient for salmonids as well as a toxicant in diets and water is widely recognized [145-147]. The essentiality of Se for several farmed fish species grown in FW and SW is now widely recognized [3,6,105]. In nature, inorganic Se is present in four different oxidation states: selenate, selenite, elemental Se and selenide. In all biological systems, these forms are converted into more bioavailable organic forms, mainly as the two seleno-amino acids selenocysteine (SeC) and selenomethionine (SeMet). Selenoproteins are responsible for diverse biological functions and they all contain at least one SeC $[148,149]$. A comprehensive study of the identification and comparative analysis of vertebrate selenoproteomes has shown more than 45 selenoproteins in mammals and among bony fishes as well as 38 selenoproteins in zebrafish [150].

$\mathrm{SeC}$ is present in vertebrates at the active sites of glutathione peroxidases, thioredoxin reductases, iodothyronine deiodinases and selenophosphate synthetases, and is an essential component of other selenoproteins, [148,151]. The biochemical functions of many of these selenoproteins are poorly understood in fish. In several organisms, there are eight glutathione peroxidases (GPXs), five of them are selenocysteine enzymes (GPX1, GPX2, GPX3, GPX4 and GPX6), whereas the other three (GPX5, GPX7 and GPX8) have a cysteine at their catalytic site $[148,152]$. The three best characterized groups of selenoproteins in fish include glutathione peroxidases, thioredoxin reductases and iodothyronine deiodinases. The GPXs are involved in hydrogen peroxide $\left(\mathrm{H}_{2} \mathrm{O}_{2}\right)$ signaling, detoxification of hydroperoxides and maintaining cellular redox homeostasis. GPX1 is the most abundant selenoprotein, which is considered a potent antioxidant in the cell scavenging of toxic $\mathrm{H}_{2} \mathrm{O}_{2}$. This protection of cells from oxidative damage by degrading toxic $\mathrm{H}_{2} \mathrm{O}_{2}$ has been closely linked to health and disease prevention in animals, humans and fish [149,153-157]. Thioredoxin reductases are also important antioxidant enzymes that maintain cellular redox status. Selenium as an integral part of GPx and thioredoxin reductase interacts with certain micronutrients (e.g., a-tocopherol) that affect redox status (i.e., pro-oxidant and antioxidant balance). The third group of selenoproteins are iodothyronine deiodinases, which activate the prohormone thyroxine (T4) to the active thyroid hormone triiodothyronine (T3), and catalyze the inactivation of T4 to reverse T3 and T3 to diiodothyronine (T2) [148].

Fish absorb limited amounts of Se from the environment via the gills and skin under certain conditions; however, the gastrointestinal tract is the primary site for Se absorption $[158,159]$. Low concentrations of selenium are found extensively in aquatic ecosystems [159]. The uptake of Se as selenite across the gills is efficient at low waterborne concentrations [147]. Selenocysteine and selenomethionine are likely to be absorbed by an active amino acid transport mechanism, whereas selenite is absorbed by simple diffusion and selenate by a sodium-mediated carrier shared with sulfate [160]. Absorbed Se is associated with proteins in the plasma and transported to tissues. After absorption from the diet, Se is transported to the liver and metabolized to selenide and incorporated into selenocysteine for selenoprotein synthesis or converted to selenosugars or methylated metabolites for excretion. Fish and other vertebrates excrete Se via feces, but urine is the primary excretion route and likely plays a quantitatively important role in Se homeostasis $[158,160]$.

Beneficial effects and toxicity of dietary Se supplementation in fish and animals are well documented $[1,47,161,162]$. The effects of dietary Se also show an increase in expression of selenoprotein P in rainbow trout and zebrafish [163-166]. In Se-adequate animals, the kidney and liver have the highest Se content. Muscle has moderate levels of 
Se content but accounts for the largest pool of body Se. Retention and distribution of Se in tissues are affected by the body Se status and chemical form of Se [167]. Selenium-deficient animals retain Se more efficiently than Se-adequate animals.

\subsubsection{Requirement}

Selenium requirements of several fish species have been determined on the basis of different response criteria (growth, liver and plasma/serum GPx activities and Se concentration of total body and tissues, e.g., liver, muscle) and are summarized in Table 3. The lack of standard methodology and form of Se used makes it difficult to compare the results of different species or within species. The minimum Se requirement of fish varies with the form of Se (inorganic or organic) ingested, Se availability from different feed ingredients from the diet, vitamin E content of the diet and concentrations of waterborne selenium. The estimated Se requirements based on weight gain, whole body Se retention and liver GSH-Px activities have shown different values for some fish species. Some studies have used a single or limited number $(<3)$ to test the requirements, which has limited value in assessing the Se requirement properly. Published data on the Se requirement of farmed animals have demonstrated that growth alone does not reflect their Se requirement. A meta-analysis of published information on Se requirements of several fish species showed different estimates for the Se requirement $\left(\mathrm{mg} \mathrm{kg}^{-1}\right)$ based on different parameters: weight gain, 0.35; enzyme activities of liver GPx, 0.78; serum GPx, 0.43; liver glutathione reductase (GR) activity, 0.41 [105]. The estimated requirement of Atlantic salmon smolts based on available Se in a plant ingredient based-diet was much lower $\left(0.27 \mathrm{mg} \mathrm{kg}^{-1}\right)$. In coho salmon, based on growth, whole body and liver Se contents, the dietary Se requirement was found to be in the range of $0.39-0.43 \mathrm{mg} \mathrm{kg}^{-1}$ [168]. Supplementation of Se-Meth as compared to sodium selenite showed lower Se requirements for Atlantic salmon smolts [169] and gibel carp [65]. In addition to differences between the bioavailability of Se from the experimental diets, Se uptake from water, age, dietary vitamin E levels and Se bioavailability and differences among fish species in the utilization of Se must be considered when published requirement values are applied in feed formulation.

Table 3. Selenium requirements of certain fish.

\begin{tabular}{|c|c|c|c|c|}
\hline Fish Species & Requirement, mg kg ${ }^{-1}$ & Selenium Source & Main Response Criteria & Reference \\
\hline Atlantic salmon & $0.27^{\mathrm{a}}(0.65)$ & $\begin{array}{l}\mathrm{Na}_{2} \mathrm{SeO}_{3} \text { or } \\
\text { SeMet }^{\mathrm{b}}\end{array}$ & Body and tissue Se & [169] \\
\hline Rainbow trout & $0.15-0.38$ & $\mathrm{Na}_{2} \mathrm{SeO}_{3}$ & Plasma GPx & [146] \\
\hline Coho salmon & $0.39-0.43$ & $\mathrm{Na}_{2} \mathrm{SeO}_{3}$ & WG, whole body, liver Se, & [168] \\
\hline Channel catfish & $\begin{array}{c}0.25 \\
0.28,0.17 \\
0.09,0.12 \\
0.11,0.12\end{array}$ & $\begin{array}{l}\mathrm{Na}_{2} \mathrm{SeO}_{3} \\
\mathrm{Na}_{2} \mathrm{SeO}_{3} \\
\text { SeMet } \\
\text { Se-yeast }\end{array}$ & $\begin{array}{c}\text { Liver and plasma GPx } \\
\text { WG }{ }^{c}, G P x \\
\text { WG, GPx } \\
\text { WG, GPx }\end{array}$ & $\begin{array}{l}{[170]} \\
{[171]}\end{array}$ \\
\hline Gibel carp & $\begin{array}{c}1.18 \\
0.73-1.19\end{array}$ & $\begin{array}{l}\text { SeMet } \\
\text { SeMet }\end{array}$ & $\begin{array}{l}\text { WG, liver GPx, tissue Se } \\
\text { Liver Se, liver SOD, T-AOC }\end{array}$ & $\begin{array}{l}{[172]} \\
{[173]}\end{array}$ \\
\hline Nile tilapia & 0.57 & SeMet & WG, liver GPx & [174] \\
\hline Largemouth bass & $1.60-1.85$ & $\mathrm{Na}_{2} \mathrm{SeO}_{3}$ & Liver GPx & [175] \\
\hline Gilthead sea bream & 0.94 & $\mathrm{Na}_{2} \mathrm{SeO}_{3}$ & Growth, liver Se & [176] \\
\hline Black sea bream & 0.86 & Se-polysaccharide ${ }^{\mathrm{d}}$ & Liver SOD and GPx & [177] \\
\hline Malabar grouper & $\begin{array}{c}0.7 \\
0.9 \\
0.98\end{array}$ & $\begin{array}{c}\text { SeMet } \\
\text { SeMet } \\
\mathrm{Na}_{2} \mathrm{SeO}_{3}\end{array}$ & $\begin{array}{l}\text { WG, Se retention } \\
\text { WG, flesh Se }\end{array}$ & $\begin{array}{l}{[178]} \\
{[179]}\end{array}$ \\
\hline Cobia & 0.8 & SeMet & $\begin{array}{l}\text { Liver and serum GPx, } \\
\text { whole body Se }\end{array}$ & [180] \\
\hline
\end{tabular}

${ }^{a}$ Based on available Se; ${ }^{b}$ Se-methionine used as Se supplement; ${ }^{c}$ weight gain; ${ }^{d}$ Se-polysachharide used as Se supplement.

\subsubsection{Deficiency}

Unlike other micronutrients, gross deficiency of Se alone has not been characterized due to its interaction with vitamin E, polyunsaturated fatty acids and other dietary 
factors. Early clinical signs of deficiency caused by low dietary intake of Se have been detected in low enzyme activities in plasma and liver glutathione peroxidase of several fish species $[145,146,170-177,180,181]$. Selenium deficiency led to reduced growth in rainbow trout [146], carp [182] and catfish [170], but Se deprivation did not lead to any pathological signs in these species. A combination of dietary vitamin E and Se was found to prevent muscular dystrophy in Atlantic salmon [145] and exudative diathesis in rainbow trout [181]. Extensive research conducted on animals shows that it is very difficult to produce or distinguish symptoms of Se deficiency alone from that of a Se-vitamin E deficiency [1].

Although the effects of selenium deficiency on the reproduction of animals are well documented [1,162] the effects of Se on the reproductive performance of fish are not clear. Recently, Wischhusen et al. [183] found that Se supplementation of diets based on a major proportion of plant ingredients enhanced the total number of spawning fish and higher levels of hydroxy-methionine supplementation led to earlier spawning in rainbow trout. There was no evidence of transfer of maternal Se to progeny and supplementation of organic Se increased GPx activity and mRNA expression of other proteins involved in antioxidant protection at the cellular levels as well as elevated tissue vitamin $C$ and E concentrations.

\subsubsection{Toxicity}

Dietary Se toxicity has been extensively studied in farm animals and the following three possible mechanisms of toxicity have been proposed: (a) substitution of Se for sulfur in important biochemical reactions and structures (e.g., disulfide bonds may disrupt normal function and cell integrity); (b) reaction between selenite and glutathione depletes cellular free and protein-bound thiol levels, thus affecting the activities of certain enzymes; (c) free radicals such as superoxide anions produced by the reactions of certain forms of Se with tissue thiols may cause oxidative injuries to tissues [1,94]. In fish, both dietary and waterborne Se toxicities have been experimentally produced [147]. The physiological mechanisms involved in the uptake of Se from water and its toxicity to fish and other aquatic organisms have been extensively investigated and are the subject of comprehensive reviews $[158,159,184]$. Waterborne inorganic forms of Se (selenate and selenite) are not absorbed appreciably through gill membranes [185] and ingestion of natural food organisms that accumulate Se from the aquatic environment appear to be more toxic [159]. The susceptibility to Se toxicity and the mode of action of Se toxicity may differ among fish due to their diverse chemical properties, uptake and metabolism from diet and water. Coho salmon are more sensitive than chinook salmon to inorganic Se [186]. As in the case of trace element bioavailability, the relative toxicity of a given Se compound is affected by its chemical form and solubility. Highly insoluble elemental Se is much less toxic to many species than other more soluble forms such as selenite and selenate $[47,158]$. Dietary selenomethionine (Se-Meth) was less toxic to chinook salmon, coho salmon and Atlantic salmon than selenite or selenate $[186,187]$. However, the Se-Meth caused Se toxicity in

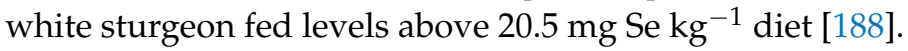

A relatively narrow range between dietary requirement and toxicity exists in fish and other vertebrates $[146,158,162]$. Selenium toxicity has been reported in rainbow trout and catfish when the dietary Se level exceeds 13 and $15 \mathrm{mg} \mathrm{kg}^{-1}$ dry feed, respectively $[146,170]$. Reduced growth, poor feed efficiency and an increase in mortality have been reported as the major adverse effects of Se when concentration exceeded the dietary requirements established for juvenile fish. In addition to reduced growth, several other adverse effects of feeding higher levels of selenite and Se-Meth in diets include decreased energy retention [189,190], lower egg viability [191], decrease in swimming activity [188], reduced immunological functions [155], pathological changes in liver, kidney and ovaries [184,192] and skeletal deformities $[167,187,193]$.

For the assessment of early sublethal adverse effects of selenite and Se-Meth toxicity, several biomarkers such as tissue lipid peroxidation, reduced glutathione (oxidative stress marker) and changes in lipid composition have also been proposed [167]. Elevated Se levels 
for rainbow trout, chinook salmon, fathead minnow, striped bass, bluegill and razorback

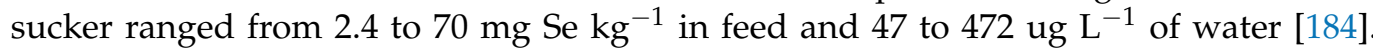
In most cases, reduced growth or survival occurred at dietary Se levels close to $3 \mathrm{mg}$ Se $\mathrm{kg}^{-1}$. Atlantic salmon tolerated either $1-2$ or $3 \mathrm{mg} \mathrm{Se} \mathrm{kg}^{-1}$ of selenite and Se-Meth supplementation, respectively, in a feed based on a high proportion of plant ingredients that contained $0.45 \mathrm{mg} \mathrm{Se} \mathrm{kg}^{-1}$ [187]. The relative toxicity of different Se supplements may be largely related to their solubility in water and nutrient bioavailability and can be modulated by dietary factors such as protein, sulfate, vitamin $\mathrm{E}$ and a number of trace elements including $\mathrm{As}, \mathrm{Cu}$ and $\mathrm{Hg}$. The maximum limit for total Se in animal feeds, including fish,

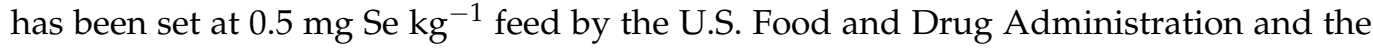
European Union [194], which is considered low to meet the Se requirement of Atlantic salmon fed diets based on plant ingredients and low in fish meal [169].

The primary biochemical mechanism for chronic Se toxicity was initially considered to be linked to the substitution of Se for sulfur in cysteine and methionine, which affected the tertiary structure of protein and its function by altering disulfide linkages [195]. Oxidative stress has been proposed as a main cause of excess dietary Se intake or exposures in fish [167]. In Atlantic salmon fed high levels of selenite and Se-Meth yeast, oxidative stress was a main driver for Se toxicity [167]; however, white sturgeon and brown trout fed high levels of organic Se did not show oxidative stress [190,196]. Altered liver lipid synthesis and metabolism have been shown to be the central mechanism in dietary organic Se toxicity in rainbow trout $[196,197]$. Wide-scope pathway assessments by the application of metabolomics techniques show that disturbance in lipid metabolism is an important factor in inorganic and organic Se toxicity [167].

\subsubsection{Bioavailability}

Feed sources of Se used in feeds are either in inorganic (selenite, $\mathrm{SeO}_{3}{ }^{2-}$, or selenate, $\mathrm{SeO}_{4}{ }^{2-}$ ) or organic (selenized yeast, Se-Meth and analogues) forms and they differ significantly in bioavailability, metabolism and toxicity. The major proportion of Se in common feed ingredients occurs as seleno-amino acids with Se-Meth being the most predominant form [1]. In addition, other minor organic forms derived from plants or yeast metabolism such as Se-adenosylselenohomocysteine, methylselenocysteine, selenocystathionine and $\gamma$-glutaminyl-Se-methylselenocysteine have been reported $[198,199]$. The Se content of feed ingredients of plant origin varies in various geographical locations to a great extent, depending on the Se concentration of the soil and its uptake. In cereal grains, it may range from $<0.1$ to $>0.8 \mathrm{mg} \mathrm{kg}^{-1}[3,200]$. Fish meals represent the best natural source of Se among the common feedstuffs with concentrations ranging from $1-2.4 \mathrm{mg} \mathrm{kg}^{-1}$, with the exception of tuna and mackerel meals where concentrations may exceed $5 \mathrm{mg} \mathrm{kg}^{-1}[3,200]$. High concentrations of Se have also been reported in shrimp meal and crab meal $[3,200]$. Selenium is widely distributed in small concentrations in FW (0.1-0.3 ug L $\left.\mathrm{L}^{-1}\right)$ and SW $\left(0.05-0.2 \mathrm{ug} \mathrm{L}^{-1}\right)$. In certain regions of the USA with highly seleniferous exposed shale

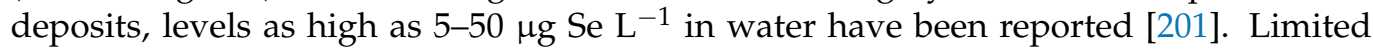
amounts of dissolved inorganic forms of Se as selenate and selenite in water are absorbed through gill membranes [185].

Several factors affect the bioavailability of Se, including form of Se, other dietary components, physiological status of Se in animals and species differences [202,203]. The effects of the chemical form of Se in feeds and feed ingredients on the bioavailability and metabolism of this element have been extensively studied in animals [202] and humans [204]. Different criteria have been used to determine the bioavailability of Se including GSH-Px activity, tissue Se concentration and prevention of Se deficiency. The activity of GSH-Px in plasma, red blood cells and a number of tissues responds to dietary Se concentration. Organic sources of Se supplements have shown a higher bioavailability as compared to inorganic forms for fish [163,169,171,205-208]. Selenium-enriched yeast showed higher bioavailability than sodium selenite [209]. Nanoforms of Se also show high 
bioavailability in vertebrates [162]; however, their bioavailability, metabolism and safety remain to be fully evaluated in fish [156].

The early work of Bell and Cowey [210] showed higher bioavailability in Atlantic salmon and it follows the order from highest to lowest: selenomethionine > selenite $>$ selenocysteine $>$ fish meal. Certain fish meals, e.g., tuna, may have poor biological availability because of heavy metal complexing of Se. A wide variation in Se availability (38.5-60\%) of different batches of capelin meal measured using GSH-Px activity in a chick bioassay was observed [211]. Until the initiatives to reduce the amount of fish meal with plant ingredients, Se supplementation of farmed fish diets was not considered necessary. An increase in plant protein sources and reduction in fish meal in feeds have reduced the level of Se and bioavailability of Se $[163,169,206,209,212-214]$. Selenium supplementation of fish diets appears to be the most effective method to meet its requirement.

\subsection{Zinc}

Zinc is the second most abundant trace element, after Fe, essential to all cells in most living organisms [215]. It has many diverse biochemical functions and is the subject of extensive studies to define the role of $\mathrm{Zn}$ at the subcellular level in nutrition and health of human and animals. Most knowledge related to the biochemical function of $\mathrm{Zn}$ has emerged from research on other vertebrates and this area is wide open for research from fish perspectives. The ubiquitous distribution of $\mathrm{Zn}$ among cells, coupled with it being the most abundant intracellular trace element, has resulted in identification of three specific functions in biology of vertebrates and plants: (a) catalytic, (b) structural and (c) regulatory. The catalytic role of $\mathrm{Zn}$ is essential for the biological function of all six classes of more than 300 enzymes [216]. Some examples are RNA nucleotide transferases (RNA polymerase I, II and III), alkaline phosphatase and carbonic anhydrases. In the structural role of metalloenzyme, $\mathrm{Zn}$ ion stabilizes the tertiary structure of enzymes (e.g., $\mathrm{Cu}-\mathrm{Zn}$ superoxide dismutase). For this enzyme, $\mathrm{Cu}$ serves at the catalytic site and $\mathrm{Zn}$ serves a role in structure. $\mathrm{Zn}$ finger (where some histidine replaces cysteine) motifs in protein represent an important structural role. The single $\mathrm{Zn}$ atom at the base of the motif influences the binding of protein to DNA. The linking of these $\mathrm{Zn}$ fingers to the corresponding sites on DNA initiates the transcription factor and initiates gene expression. Approximately $3000 \mathrm{Zn}$ proteins in the human genome and fish genome carry "Zn binding" annotation [217]. Zinc is required for the structural and functional integrity of over 2000 transcription factors and almost every signaling and metabolic pathway is dependent on one or more zinc-requiring proteins [218]. Additionally, $\mathrm{Zn}$ as an intracellular regulatory ion activates or inhibits transcription factors responsible for regulating gene expression. An example of this role is metallothionein (MT) or MT-like proteins.

The homeostasis of $\mathrm{Zn}$ is controlled at the whole body, tissue, cellular and subcellular levels by different proteins involving zinc transporters. Two $\mathrm{Zn}$ transporter families, $\mathrm{Zn}$ transporters (ZnT) and Zrt/Irt-like proteins (ZIP), function in the mobilization, influx, efflux, compartmentalization and sequestration across biological membranes [219]. ZnT and ZIP thus contribute to a wide range of physiological and cellular functions (e.g., immune, endocrine, reproductive, skeletal and neuronal) by tightly controlling zinc homeostasis [219,220]. Biochemical roles for $\mathrm{Zn}$ transporters and regulation of specific genes have mainly been studied in the zebrafish model [221,222].

Like other trace elements, the main routes of zinc uptake from water are through the gills and gastrointestinal tract; however, the major route of $\mathrm{Zn}$ absorption is the gastrointestinal tract both in FW and SW [223]. Waterborne and dietary $\mathrm{Zn}$ is also a potential source of this mineral for salmonids and marine fish because they drink SW [224,225]. In FW fish, uptake across the gill can contribute significantly $(\sim 50 \%)$ to total $\mathrm{Zn}$ absorption if the $\mathrm{Zn}$ concentration in the water is high or that in the diet too low. Zn may interfere with calcium homeostasis by competitive inhibition of $\mathrm{Ca}^{2+}$ transfer across the apical membrane of the gill epithelial cells by $\mathrm{Zn}^{2+}$ [226]. An excessive uptake and accumulation of $\mathrm{Zn}$ in the gills is also regulated through alteration in $\mathrm{Zn}$ uptake mechanisms [14]. Chelation of $\mathrm{Zn}$ with 
amino acids, such as histidine or cysteine which have a high affinity for this element, may enhance $\mathrm{Zn}$ absorption and distribution in the tissues of fish [97]. The excretion of dietary $\mathrm{Zn}$ through gills has also been observed in rainbow trout [227].

Waterborne $\mathrm{Zn}^{2+}$ shares part of a common pathway with $\mathrm{Ca}^{2+}$ for uptake in the gills of FW fish [19] and Ca may have either inhibitory or stimulatory effects on Zn absorption depending on concentration $[83,217]$. An interaction between high levels of dietary Ca and $\mathrm{Zn}$ in water may protect FW fish from $\mathrm{Zn}$ toxicity [228]. Zinc accumulation in gills also affects additional $\mathrm{Zn}$ uptake from water and is considered an important physiological mechanism to maintain $\mathrm{Zn}$ homeostasis by limiting its excessive absorption [14]. In addition, the control of absorption by the gastrointestinal tract and excretory mechanisms plays an important role in $\mathrm{Zn}$ homeostasis. Zinc is excreted via bile in urine, the sloughing off of intestinal mucosa in feces and gills in fish [19]. Limited information exists on absorption of dietary $\mathrm{Zn}$ from the gastrointestinal tract and transport mechanisms as free $\mathrm{Zn}$ ions or bound to certain amino acids [14,18]. Information on the absorption of $\mathrm{Zn}$ from the gut is limited. In the intestine, dietary $\mathrm{Zn}$ binds to the mucus of the intestinal epithelium, and is transported into the epithelial cells either as $\mathrm{Zn}$ ions or as ions bound to amino acids $[14,18]$. It is well known that high intakes of phytate and iron reduce the absorption of zinc [6]. In vitro studies using a recently developed enterocyte model have the potential to better understand the mechanisms involved in the absorption of inorganic and organic $\mathrm{Zn}$ in fish feeds and $\mathrm{Zn}$ supplements [229].

\subsubsection{Requirement}

A dietary requirement for $\mathrm{Zn}$ has been reported for several juvenile fish species (Table 4). The minimum $\mathrm{Zn}$ requirement varies with age, sexual maturity, composition of diet, water temperature and water quality [3]. The response criteria used to determine $\mathrm{Zn}$ requirements of fish in various studies include growth, feed efficiency, deficiency signs, whole body $\mathrm{Zn}$ concentration and retention, serum or plasma levels and enzyme activities. Most of the above criteria show responses to increasing dietary concentration, and the major proportion of dietary $\mathrm{Zn}$ is retained in skeletal tissues, particularly vertebrae. A meta-analysis of published information on $\mathrm{Zn}$ requirements of several fish species showed estimates ranging from $33.5-64.6 \mathrm{mg} \mathrm{kg}^{-1}$ on the basis of different parameters tested (weight gain, 36; whole body $\mathrm{Zn}$, 33.5; vertebrae $\mathrm{Zn}$, 64.6; serum Zn, 53.4; serum ALP activity, 47) [105].

Table 4. Zinc requirements of certain fish ${ }^{\mathrm{a}}$.

\begin{tabular}{|c|c|c|c|}
\hline Fish Species & $\begin{array}{l}\text { Requirement, } \\
\text { mg kg }^{-1}\end{array}$ & Main Response Criteria & Reference \\
\hline Atlantic salmon & $37-67$ & Body and serum $\mathrm{Zn}$ & [230] \\
\hline \multirow{2}{*}{ Rainbow trout } & $15-30$ & $\mathrm{WG}^{\mathrm{b}}$, vertebral $\mathrm{Zn}$ & [231] \\
\hline & 30.1 & WG & [232] \\
\hline Channel catfish & 20 & WG, vertebral Zn & [233] \\
\hline Yellow catfish & $17.1-20.9$ & WG, PER ${ }^{c}$ & [234] \\
\hline Common carp & 15 & WG, vertebral Zn & [235] \\
\hline Jian carp & $43.2-48.7^{\mathrm{d}}$ & WG, serum $\mathrm{Zn}$ & [236] \\
\hline Grass carp & 55 & $\begin{array}{l}\text { WG, whole body, vertebral, scale } \\
\text { and tissue } \mathrm{Zn}\end{array}$ & [237] \\
\hline Indian major carp & $47.8-52.9$ & $\begin{array}{l}\text { WG, vertebral, scale serum and liver } \\
\text { Zn }\end{array}$ & [238] \\
\hline \multirow{2}{*}{ Hybrid tilapia } & $26-29$ & WG, whole body Zn & [239] \\
\hline & $105-115^{\mathrm{e}}$ & WG, whole body and plasma $\mathrm{Zn}$ & [240] \\
\hline
\end{tabular}


Table 4. Cont.

\begin{tabular}{cccc}
\hline Fish Species & $\begin{array}{c}\text { Requirement, } \\
\text { mg kg }\end{array}$ & Main Response Criteria & Reference \\
\hline Blue tilapia & 20 & Scale and vertebral Zn & {$[241]$} \\
\hline Nile tilapia & 30 & WG, vertebral and serum Zn & {$[242]$} \\
& $37.2-52.1$ & WG, bone Zn & {$[243]$} \\
\hline Russian sturgeon & $28.2-34.6$ & WG and liver Zn & {$[245]$} \\
\hline Red drum & 20 & WG, serum and bone Zn & {$[246]$} \\
\hline Blunt snout sea bream & $52.1^{\mathrm{f}}, 86.2^{\mathrm{f}}$ & WG, whole body Zn & {$[247]$} \\
\hline Malabar grouper & $28.9-33.7$ & WG, vertebral and scale Zn & {$[248]$} \\
\hline Cobia & 42.9 & WG, vertebral Zn &
\end{tabular}

a Unless specified, $\mathrm{ZnSO}_{4} \cdot 7 \mathrm{H}_{2} \mathrm{O}$ used as $\mathrm{Zn}$ supplement; ${ }^{\mathrm{b}}$ weight gain; ${ }^{\mathrm{c}}$ protein efficiency ratio; ${ }^{\mathrm{d}}$ zinc lactate $\left(\mathrm{C}_{6} \mathrm{H}_{10} \mathrm{O}_{6} \mathrm{Zn}\right) ;{ }^{e}$ diet based on soybean meal; ${ }^{\mathrm{f}}$ requirements based on weight gain and whole body $\mathrm{Zn}$, respectively.

\subsubsection{Deficiency}

Overt signs of Zn deficiency are difficult to produce in short-term experiments due to the ubiquity of this trace element in water and feed ingredients. Early work of Ogino and Yang [231] showed lens cataracts, erosion of fins and skin as well as growth depression and high mortality in juvenile rainbow trout fed semi-purified diet containing a low level of Zn. Satoh et al. [136,182] observed short body dwarfism due to poor mineralization of trout vertebrae. In several fish species, low dietary Zn intake caused reduced growth, low serum, liver, scale, body and vertebral $\mathrm{Zn}$ concentrations. Widespread occurrences of cataracts in salmonids fed diets based on high amounts of white fish meal in United States hatcheries were attributed to Zn deficiency [249]. Zinc is considered essential for normal eye development in juvenile fish and high levels of dietary $\mathrm{Ca}$ and $\mathrm{P}$ in fish meal and phytic acid in plant ingredients reduce $Z n$ bioavailability, resulting in lens cataracts $[232,249,250]$. Dietary histidine has also been found to prevent development of cataracts in Atlantic salmon smolts [251]. Zinc and multiple dietary, genetic and environmental factors may be involved in the pathogenesis of cataracts in Atlantic salmon [30,252,253]. Broodstock diets low in $\mathrm{Zn}$ reduced egg production and hatchability of eggs in rainbow trout [126]. Caudal fin $\mathrm{Zn}$ concentration is considered a good indicator of $\mathrm{Zn}$ status in rainbow trout [254].

\subsubsection{Toxicity}

Excessive dietary zinc levels may become toxic to fish and compete for similar binding sites with other bivalent minerals such as $\mathrm{Cu}, \mathrm{Fe}, \mathrm{Ca}$ and $\mathrm{Cd}$ in the digestive tract during absorption [80,234]. Rainbow trout and carp can tolerate 1700 to $1900 \mathrm{mg}$ zinc kg-1 in the diet without any apparent signs of toxicity [255]. Common carp accumulate higher concentrations of $\mathrm{Zn}$ in their tissues, particularly in the viscera, than other fish studied, without any overt toxicity signs [256]. In rainbow trout, high concentrations of dietary $\mathrm{Zn}$ (500 to 1,000 $\mathrm{mg} \mathrm{Zn} \mathrm{kg}^{-1}$ ) caused reduced hemoglobin, hematocrit and hepatic $\mathrm{Cu}$ concentrations in rainbow trout [49].

Effects of environmental pollution and heavy metal contamination of aquatic organisms have been the subject of intensive research, particularly their accumulation in fish [257]. Uptake and toxicity of zinc and other metals from water are known to vary, depending on the physiological status and osmoregulatory mechanisms [232,258]. The toxic effects of $\mathrm{Zn}$ have been studied mainly in FW, which show that hypocalcemia caused by $\mathrm{Zn}$ interferes with active $\mathrm{Zn}$ uptake at the gills [18]. Sublethal $\mathrm{Zn}$ exposure of killifish in FW and SW caused pathological changes in both $\mathrm{Ca}$ and $\mathrm{Na}$ homeostasis and an increase in salinity exerted protective effects against sublethal and lethal $\mathrm{Zn}$ toxicities $[258,259]$. Mineral sensitivity is highest during the larval stage, compared to other times in the life history of a fish. The zinc content of scales reflects environmental metal concentrations [18]. 


\subsubsection{Bioavailability}

Dietary factors (e.g., form of Zn, protein source, phytic acid, and dietary Ca and P levels) are known to affect absorption and retention of $\mathrm{Zn}$ in fish [214,227,232,233,241,250,254,260-262]. In most $\mathrm{Zn}$ requirement studies (Table 4$)$, zinc sulfate $\left(\mathrm{ZnSO}_{4} \cdot 7 \mathrm{H}_{2} \mathrm{O}\right)$ has been used due its high bioavailability. Both zinc sulfate and zinc nitrate $\left(40 \mathrm{mg} \mathrm{kg}^{-1}\right)$ alleviated dwarfism and cataract problems in rainbow trout [260]. The bioavailability of $\mathrm{Zn}$ oxide is low in Atlantic salmon and other fish species, probably due to the lower solubility of this compound [6]. Recent studies on monogastric animals show high variability of zinc oxide feed supplements in color, texture and Zn content and manufacturing techniques, which affects their bioavailability [263]. Organically complexed minerals (amino acid chelate, yeast complexes, etc.), including zinc, appear to be more readily available to rainbow trout compared with inorganic sources [205,262,264-266]. No apparent differences in the bioavailability of zinc sulfate and zinc methionine were observed in catfish [267]. In gilthead seabream, zinc oxide was found to be very effective for eliciting good whole body growth response, whereas the chelated form appeared to induce greater antioxidant responses [268]

Although fish meal produced from whole fish (e.g., herring and capelin meal) is considered a good source of $\mathrm{Zn}$ ( 80 to $130 \mathrm{mg} \mathrm{Zn} \mathrm{kg}^{-1}$ ) and other minerals, the concentration of $\mathrm{Zn}$ varies in meals produced from processing discards containing partial fish parts. Feed ingredients of animal origin (meat and bone meal, poultry feather meal) contain high zinc levels $\left(90^{-1} 40 \mathrm{mg} \mathrm{Zn} \mathrm{kg}^{-1}\right.$ ). High levels of $\mathrm{Ca}$ and $\mathrm{P}$ in high-ash fish meal and meat and bone meal affect the bioavailability of Zn $[6,11,139,269]$. Phytate in plant products, especially cereals and legumes, irreversibly binds zinc in the intestinal lumen and reduces its bioavailability. Furthermore, there are copper-zinc and calcium-phytate-zinc antagonistic interactions, which can decrease bioavailability of $Z n$ to rainbow trout $[6,11,139,269,270]$. Fiber may interfere with $\mathrm{Zn}$ absorption but this may be attributed to the phytate content of high-fiber plant feedstuffs. Amino acids, such as histidine and methionine, and other low-molecular-weight ions, such as EDTA and organic acids (e.g., citrate), are known to have a positive effect on $\mathrm{Zn}$ absorption [270]. The removal or reduction of phytate by enzyme (phytase) treatment, fermentation or plant breeding/genetic engineering markedly improves $\mathrm{Zn}$ absorption [271]. Increasing levels of $\mathrm{Cd}$ in foods associated with environmental contaminants and other factors has also been shown to reduce zinc absorption [270]. A higher limit in fish feed has been set for salmonids ( $150 \mathrm{mg} \mathrm{kg}^{-1}$ of diet) and other fish (100 $\mathrm{mg} \mathrm{kg}^{-1}$ of diet) in Europe [263].

\subsection{Iodine}

Iodine is an essential constituent of the thyroid hormones T3 (3,5,3'-triiodo-L-thyronine) and T4 (L-thyroxine; 3,5,3', $5^{\prime}$-tetraiodo-L-thyronine) that regulate cell activity and growth in all tissues. The metabolism of thyroid hormones (THs) and iodine which mainly exists as inorganic iodide are closely linked, and THs play a critical role in cellular oxidation, hematopoiesis, circulation, reproduction, neuromuscular functioning and metabolism of major nutrients [272]. T3 is the predominant hormone secreted by the thyroid gland and is regarded as an active precursor for T4. T3 is more biologically active than T4 in several fish species [273,274]. The inhibition of extrathyroidal T4-to-T3 conversion reduces the potency of thyroid hormone [275,276]; however, the mode of action of the less active T4 is not fully established. Thyroid has an established role in development and metamorphosis [277,278], and where TH metabolism could differ. Major differences exist between fish and mammals in the physiology of I and extrathyroidal metabolism of T4 and T3 as reviewed by Eales [279].

The branchial uptake of iodide by fish is widely recognized. Marine fish drink SW, ensuring an adequate intestinal I absorption, which is supplemented by I in food and possible I uptake through body surfaces [280]. FW fish drink negligibly, hence, dietary and gill uptake are both considered important sources of I [273,281]. Most research on I metabolism in fish has been focused on salmonids in the FW phase of their lifecycle. In rainbow trout, approximately $19 \%$ I is derived from diet, $80 \%$ from water, and less than 
$1 \%$ from recycling iodide originating from thyroid hormone degradation [282]. Salmonids undergo parr-smolt transformation, with established thyroid involvement [283]. After the growth phase during sexual maturation and reproduction, some changes in thyroidal status occur as well as interaction of THs with sex-related hormones [274,284]. Female fish transfer significant amounts of thyroid hormones to developing ova $[277,285]$ and the offspring may rely on parental I storage to complete their early development. Some of these physiological changes may affect the I metabolism and requirement at different stages of the life cycle of fish [273].

Iodine enrichment of live food organisms such rotifers, copepods and Artemia to increase their I concentration has been tested with cod, halibut and Senegal sole larvae [286-288]; however, its retention was low in some species, probably due to differences in the bioavailability of I from water or the form of I compounds used to increase the I concentration [289]. Penglase et al. [288] have, however, clearly demonstrated that rotifers could be successfully enriched with I. Feeding cod larvae a high concentration of I-enriched rotifers (129 $\left.\mathrm{mg} \mathrm{I} \mathrm{kg}^{-1} \mathrm{DW}\right)$ caused I toxicity. Ozone treatment of sea water in the recirculation systems oxidizes I to an unavailable $\mathrm{IO}^{3-}$ form, which has low bioavailability for fish [290]. Nitrate $\left(\mathrm{NO}^{3-}\right)$ is considered goitrogenic for fish and as its build-up in water may block iodide uptake by the sodium iodide symporter [291], which can even cause goiter in sharks [292].

The relation of I deficiency to enlargement of the thyroid gland or goiter in salmonid fish was first shown by [293]. Senegalese sole larvae developed thyroid hyperplasia and hypertrophy when fed Artemia and grown in a recirculation system [287]. In vertebrates, other deficiency signs of I include goiter, cognitive and neuromuscular retardation, embryonal and postnatal mortality and impaired fertility [294]. Excessive I intake can also negatively affect thyroid hormone production and produce goiter, termed I or colloid goiter in humans [295]. In most fish species, I requirement and deficiency remain to be investigated. Woodall and LaRoche [296] found a higher iodine requirement for advanced parr compared to fingerlings due to increased thyroid activity during smoltification. Lall et al. [297] observed that $4.5 \mathrm{mg} \mathrm{I} \mathrm{kg}^{-1}$ of diet was essential to protect Atlantic salmon from bacterial kidney disease infections. It is likely that I requirement is influenced by growth, sex, age, physiological status, environmental stress, disease and iodine content of the water.

Few definitive studies on iodine bioavailability have been conducted due to high uptake of I from water and the problem with distinguishing absorption from water and dietary sources. Iodine concentration of marine fishes is relatively high [298,299]; however, substantial amounts of iodine are lost during fish meal processing [6]. Ingested inorganic iodine and iodate are reduced to iodide and absorbed almost completely from the gastrointestinal tract [272]. Certain seaweeds also contain high levels of iodine [300]. Goitrogenic substances in feed may increase iodine requirements depending on the amount and type of this natural toxicant [301]. Glucosinolates (GLSs) in rapeseed meal are known to impair thyroid function, causing goiter in vertebrates [302] and possibly also in fish [273,303]. This effect is caused by their hydrolytic products (e.g., thiocyanate anions, visnyloxazolidinethiones and isothiocyanates). The thiocyanate anions are competitors of iodine for active transport across the cell membrane and for binding to tyrosine residues of thyroglobulin. Burel et al. [304] showed that dietary supplementation with T3 or iodine induced an increase in plasma T3 levels, as compared to fish fed rapeseed meal diets, and reduced the deleterious effect of rapeseed meal (RM) on growth. Processing methods as well as novel varieties have been developed to overcome these antinutritional factors in rapeseed products [305].

\subsection{Chromium}

Chromium is a transition metal that exists in food and the environment as $\mathrm{Cr}^{3+}$ (trivalent) and $\mathrm{Cr}^{6+}$ (hexavalent) forms. These naturally occurring oxidation states differ significantly in their bioavailability and toxicity. Trivalent $\mathrm{Cr}$ has been postulated to be involved in regulating carbohydrate and lipid metabolism by enhancing insulin's 
efficacy [306]. No Cr-dependent enzymes have been identified. The precise biochemical mechanism of $\mathrm{Cr}$ as an essential trace element is not clearly known; however, it has been shown that $\mathrm{Cr}$ binds to an oligopeptide to form chromodulin, a low-molecular-weight, chromium-binding substance that binds to and activates the insulin receptor to promote insulin action [307]. It may also have antioxidant effects. Recent research has suggested that although pharmacologic amounts of $\mathrm{Cr}$ as a therapeutic agent might increase insulin sensitivity and affect lipid metabolism, it is not an essential mineral [307,308]. This is because, according to the definition of an "essential trace element", its absence or deficiency from the diet does not produce abnormalities that can be reversed with the addition of Cr. Molecular mechanisms have been proposed for the beneficial effects of $\mathrm{Cr}$ but have not been definitively shown to occur consistently in all animals.

Chromic oxide is commonly used as an inert tracer in studies on measuring apparent digestibility coefficients with fish or shrimp. Some specific studies on the effect of $\mathrm{Cr}$ in fish have been related to its role in metabolism [309-316], growth [317,318] and toxicity [319]. To date, many of these studies have provided some evidence that $\mathrm{Cr}$ has an effect on the metabolism of fish; however, the $\mathrm{Cr}$ forms tested and their level as well as experimental conditions were different in these reports. Chromium yeast appears to modulate the immune response of rainbow trout, and this effect was both dose and time dependent [320]. Information on the need for supplemental chromium in practical diets of certain animals including fish was too sparse to allow any conclusions [47]. A need for research designed to create reproducible signs of chromium deficiency in animals, which would facilitate the establishment of dietary chromium requirements, was identified.

Chromium is absorbed across the gills and transported via blood to tissues but mechanisms of absorption from gills and the gastrointestinal tract and excretion are not known. Studies on the uptake of $\mathrm{Cr}$ from water as it relates to physiology and toxicology have been reviewed [321]. The toxic $\mathrm{Cr}^{6+}$ readily passes through cellular membranes and is then reduced to the trivalent form. This $\mathrm{Cr}^{3+}$ combines with several macromolecules including genetic material inside the cytosol, and ultimately exposes the toxic and mutagenic alterations of $\mathrm{Cr}$ toxicity. Higher levels of $\mathrm{Cr}$ in diet and water caused histological changes in the intestine, gills, liver and kidney but the mechanism of toxicity remains to be established [321,322].

\subsection{Cobalt}

Cobalt is a component of vitamin $\mathrm{B}_{12}$, collectively called "cobalamins". Methylcobalamin and 5-deoxyadenosylcobalamin are the metabolically active forms of this vitamin, however, two other forms, hydroxycobalamin and cyanocobalamin, are converted to the active forms methylcobalamin and 5-deoxyadenosylcobalamin. Microbiota in the digestive tract of ruminants and algae are known to synthesize vitamin $B_{12}$ from inorganic cobalt sources. Monogastric animals and fish require vitamin $B_{12}$ because they lack the ability to synthesize this vitamin from dietary Co in sufficient amounts by microbiota in their digestive tract. In certain warmwater fish, intestinal synthesis of vitamin $B_{12}$ by microorganisms appears to satisfy the requirements of this vitamin for Nile tilapia [323,324] and hybrid tilapia [324], but not for channel catfish [325]. The estimated dietary Co requirement reported for Tilapia zillii was about $100 \mathrm{mg} \mathrm{Co} \mathrm{kg}^{-1}$ of diet [326]. A lower concentration of Co $\left(10 \mathrm{mg} \mathrm{Co} \mathrm{kg}^{-1}\right)$ in the diet promoted gastrointestinal bacterial synthesis of vitamin $B_{12}$ in Malabar grouper and met the dietary requirement of this vitamin [327].

Cobalt is absorbed by FW fish via the gills and gut as the main routes of uptake [328,329]. Some uptake of cobalt occurred in rainbow trout eggs during embryonic development [330]. The uptake routes, homeostasis and mechanism of Co toxicity have been reviewed [329]. The levels of Co normally present in common feed ingredients, animal and fish diets are relatively low and do not cause toxicity $[1,47]$. 


\subsection{Boron}

Boron is an essential nutrient for plants as well as algae, but biological functions required to establish its essentiality for humans and animals are not clearly identified. To date, boron has been found to be essential for only zebrafish to complete their life cycle [331]. It also stimulates embryonic growth in trout [332] and zebrafish [331]. Boron has beneficial effects on such functions as reproduction and development, calcium metabolism, bone formation, brain function, insulin and energy substrate metabolism, immunity and the function of vitamin D and steroid hormones [333,334]. As compared to FW, the concentration of boron in the marine environment is relatively high $(0.4 \mathrm{mM})$, which is efficiently taken up by algae [335]. Acute toxicity of B to fry of Chinook salmon and Coho salmon has been reported [186].

\subsection{Cadmium}

Cadmium is a heavy metal that does not have a clear physiological function as a nutrient and is considered a toxicant for fish by its uptake from the aquatic environment. The toxicity of $\mathrm{Cd}$ causes the disruption of $\mathrm{Ca}$ ion homeostasis and to some extent $\mathrm{Na}$ and $\mathrm{Mg}$ [25]. Cadmium enters the gill epithelium via the same pathway as $\mathrm{Ca}^{2+}$ (apical $\mathrm{Ca}^{2+}$ channel of the chloride cells) and inhibits basolateral $\mathrm{Ca}^{2+}$ ATPase, thereby blocking active $\mathrm{Ca}^{2+}$ uptake [336]. Atlantic salmon fed $25 \mathrm{mg} \mathrm{Cd} \mathrm{kg}^{-1}$ showed inhibition of ATPdependent $\mathrm{Ca}$ uptake measured as $\mathrm{Ca}^{2+}$ and $\mathrm{Na}^{+} / \mathrm{K}^{+}$-ATPase in the intestine [87]. Generally, the concentration of $\mathrm{Cd}$ in most feed ingredients is relatively low [337].

\subsection{Arsenic}

The biochemical role of arsenic as an essential micronutrient for fish and higher animals is not clearly established; however, its dietary deprivation affects the physiological functions of certain animals [47]. Arsenic is ubiquitous in nature as an oxyanion with an oxidation state of either $3^{+}$or $5^{+}$, but it also forms compounds where As has an oxidation state of $3^{-}$. In general, it is trivalent. As compounds, inorganic (arsenite) and organic (monomethyl arsenic) forms are considered more toxic than pentavalent compounds. More than 25 different arsenic species have been identified in marine biota [338]. Arsenic binds covalently with most metals and non-metals and forms stable organic compounds. In fish and animal tissues, inorganic As occurs mainly as arsenate, and in the methylated form as dimethylarsinic acid and monomethylarsonic acid. Arsenic in algae is transferred via the food chain to other aquatic organisms [338]. The major organic arsenic species in fish and other marine organisms are arsenobetaine and arsenocholine [339], and in seaweed and microalgae, aresenosugars (dimethylarsinoyl ribosides) [340]. About $80 \%$ or more of As in fish is organic As, with arsenobetaine being the dominant species in marine fish [47]. In freshwater fish, As concentration is much more variable than in marine fish. Lipids of marine fish and other marine organisms contain As as arsenolipid and have been comprehensively reviewed [341].

Arsenic is far less toxic to fish and other vertebrates [47] than most other metals. The incorporation of As in the diet of rainbow trout to induce toxicity showed reduced growth and As accumulation in several tissues [342,343]. Arsenic concentration of feed ingredients of terrestrial and aquatic origin used in fish feeds depends on As uptake from soil by plants and aquatic food organisms consumed by fish, which varies widely in different regions of the world. Fish products including meal and oil show a wide range of As concentrations [344]. In a study designed to investigate the As content of fish meals and fish oils of two different geographic origins, Sissener et al. [212] found a wide variation in As concentration of North Atlantic $\left(9.9 \mathrm{mg} \mathrm{As} \mathrm{kg}^{-1}\right)$ and South American $\left(9.9 \mathrm{mg} \mathrm{As} \mathrm{kg}^{-1}\right)$ fish meals. However, the fish oils from these two origins showed relatively similar As levels $\left(\sim 9.3 \mathrm{mg} \mathrm{As} \mathrm{kg}^{-1}\right)$. Insect meals produced from insects raised on seaweeds showed an increase in As concentration, which was detected in Atlantic salmon fed diets based on these meals [345]. Effects of As contamination of common food sources including seafood 
and water have been the subject of major concern from the perspective of human and animal health and are beyond the scope of this review.

\subsection{Other Trace Elements}

Biochemical functions of other trace elements $(\mathrm{F}, \mathrm{Li}, \mathrm{Ni}, \mathrm{Pb}, \mathrm{Si}$ and $\mathrm{V})$ have been shown in animals and humans, but their dietary essentiality based on the defined criteria of physiological impairment has not been widely accepted. These minerals have been studied in fish mostly from physiological aspects of their uptake from water and toxicity.

\section{Macrominerals}

\subsection{Calcium and Phosphorus}

Calcium and phosphorus play a major role in the development and maintenance of the skeletal system and perform many other physiological functions including the maintenance of acid-base equilibrium [346]. In skeletal tissue, $\mathrm{Ca}$ and $\mathrm{P}$ are deposited as tricalcium phosphate $\mathrm{Ca}_{3}\left(\mathrm{PO}_{4}\right)_{2}$, which then undergoes further crystalline changes to form hydroxyapatite, $\mathrm{Ca}_{10}\left(\mathrm{PO}_{4}\right)_{6}(\mathrm{OH})_{2}$, which is deposited in the organic matrix during mineralization. The ratio of $\mathrm{Ca}$ to $\mathrm{P}$ in bone may show some changes during development, however, their ratio reported in several fish species ranges from 1.6:1 to 2:1. Fish scale is also a calcified tissue and serves as an internal Ca reservoir during periods of increased Ca demand, such as sexual maturation and starvation [347]. During the reproductive period, the plasma Ca level increases in females, which is bound to vitellogenin, a major component of egg protein and a calcium-binding protein [348].

Fish absorb $\mathrm{Ca}$ and $\mathrm{P}$ from the surrounding aquatic environment via gills, gastrointestinal tract and integument; however, the gills represent the major site of Ca uptake [7]. The physiological aspect of Ca uptake at the gills is well established and is the subject of several reviews [349-351]. The absorption and metabolism of Ca depends not only on its concentration in the surrounding water, but it is affected by species differences and their homeostasis by the endocrine system, biological availability from diet and P level [96]. Osmoregulation allows them to control their Ca levels predominantly via the hypocalcemic hormones stanniocalcin and calcitonin. Certain minerals (e.g., $\mathrm{Cd}, \mathrm{Cu}, \mathrm{Mg}$, Sr, $\mathrm{Zn}$ ) may reduce $\mathrm{Ca}$ absorption from gills or gastrointestinal tract. In vertebrates, vitamin $\mathrm{D}$ is known to play an essential role in Ca metabolism. Although limited research has been conducted on fish, the function of the endocrine system and metabolites identified appears similar in fish and terrestrial vertebrates [328,352-354].

In addition to skeletal tissue metabolism, $\mathrm{P}$ as phosphate $\left(\mathrm{HPO}_{4}{ }^{2-}\right)$ plays a major role in the function of all cells. It is a major signaling molecule, and a structural component of cell walls, essential for the nucleic acid helical structure (i.e., RNA and DNA), and a component of high-energy compounds (i.e., AMP, ADP and ATP). Food is the main source of $\mathrm{P}$ for fish because FW and SW are low in phosphate. Thus, regulation of phosphate is considered more critical than that of Ca because fish must effectively absorb and conserve phosphate in both FW and SW environments. Dietary P concentration is a major regulator of $\mathrm{P}$ metabolism in fish [355]. The amount of phosphate absorbed from the food is affected by the level of phosphate in the blood [6]. The serum concentration of phosphate and the total body content of phosphate are highly regulated and movement into cells is mediated by sodium-phosphate co-transporters [356].

Information on the endocrine regulation of $\mathrm{P}$ homeostasis in fish is limited. The hormones involved in phosphate regulation include ST, prolactin and parathyroid-like hormones (Pth1h). With the rise in serum Ca, stanniocalcin is secreted by the corpuscles of Stannius to inhibit gill and intestinal Ca transport and to promote $\mathrm{P}$ reabsorption in the kidney to maintain normal physiological serum Ca and P levels [357,358]. Parathyroid hormone-like hormones, Pth3 and Pth4, play an important role in functions related to $\mathrm{P}$ and bone mineral homeostasis $[359,360]$. It is also not clear whether the effect is mediated by the vitamin D metabolites as happens in terrestrial vertebrates [361]. Although intraperitoneal injection of vitamin D metabolites influences P homeostasis [362], dietary intake 
of cholecalciferol had no clear effect on P absorption and retention in rainbow trout [363]. Fjelldal et al. [364] observed that when reared under continuous light, low-P diets affected their plasma $25(\mathrm{OH}) \mathrm{D}_{3}$ concentration and normal bone development, indicating a need for an optimum level of dietary P. Low-P diet affected bone osteoblast and osteoclast activity and plasma $1,25(\mathrm{OH})_{2} \mathrm{D}_{3}$ levels, whereas the photoperiod had an effect on bone osteoclast activity and plasma $25(\mathrm{OH}) \mathrm{D}_{3}$ level.

\subsubsection{Requirement}

The Ca requirement of fish is affected by dietary factors (e.g., bioavailability, P level), uptake from water and species differences [3,365]. Generally, a large part of the Ca requirement of most fish is met by its absorption through gills in FW and by drinking SW. A low concentration of calcium $(0.34 \%$ or less) is required in the diet of carp, red sea bream, striped bass, tilapia, catfish and chum salmon [366-371]. Catfish and tilapia reared in water with a low calcium concentration $\left(<1 \mathrm{mg} \mathrm{Ca} \mathrm{L}^{-1}\right)$ required $0.45 \%$ and $0.7 \%$ calcium in the diet, respectively [372,373]. Atlantic salmon absorb Ca from SW, thus making dietary supplementation unnecessary [225]. There is a relatively low requirement $(0.1-0.25 \%)$ of $\mathrm{Ca}$ for farmed marine fish [3]. Other details related to Ca utilization and requirements of certain fish species have been reviewed by Hossain and Yoshimatsu [365] and Lall [96].

The P requirement $(\mathrm{g} / 100 \mathrm{~g})$ of a wide range of fish species reared in fresh, brackish and SW have been reported. Requirement in FW: Atlantic salmon, 0.6-1.0 [374-376]; rainbow trout, 0.34-0.8 [367,377,378]; chum salmon, 0.5-0.6 [379]; channel catfish, 0.330.8 [370,380,381]; milkfish, 0.85 [382]; blue tilapia, 0.5 [373]; Nile tilapia, 0.65-0.86 [383,384]; common carp, 0.6-0.7 [367]; gibel carp, 0.67-1.07 [385]; grass carp, 0.85 [386]; crucian carp, 0.78-0.83 [387]; stinging catfish, 0.9-1.1 [64]; African giant catfish, 1.23 [388]; walking catfish, 0.58-0.73 [389]; Chinese sucker, 0.83-0.86 [390]; hybrid striped bass, 0.5 [391]; snakehead, 0.96 [392]; tambaqui, 0.7 [393]; Japanese eel, 0.29 [63]. Requirement in brackish water (salinity, 5-6 0/00): red drum, 0.86 [394]. Requirement in SW: Atlantic salmon, 0.6 [225]; red sea bream, 0.68 [395]; gilthead seabream, 0.75 [396]; black seabream, 0.55 [397]; haddock, 0.96 [398]; Japanese seabass, 0.86-0.90 [399]; European seabass, 0.65 [400]; orange spotted grouper, 1.09 [401]; yellow croaker, 0.89-0.91 [402]; Japanese flounder, 0.6-1.5 [403-405].

The requirement estimates mentioned above are mainly based on studies undertaken with juvenile fish and there were differences in dietary sources of $\mathrm{P}$ and their bioavailability, fish size and response criteria selected. Antony Jesu Prabhu et al. [406] used a metaanalysis approach to estimate the $\mathrm{P}$ requirements based on published information on $\mathrm{P}$ utilization for 40 different fish species where requirement values were determined using differences in the response criteria. They found that requirements based on weight gain and $\mathrm{P}$ concentrations of the whole body and vertebrae were $0.35,0.47$ and $0.52 \mathrm{~g}$ available $\mathrm{P} / 100 \mathrm{~g}$ diet (dry matter basis), respectively. Some of these estimates differed from the NRC recommendation on P requirements $(\mathrm{g} / 100 \mathrm{~g})$ for major farmed fish species: Atlantic salmon, 0.8; rainbow trout, 0.7; Pacific salmon, 0.6; channel catfish, 0.33; common carp, 0.7; Tilapia sp., 0.4; hybrid striped bass, 0.5; red drum, 0.8; European seabass, 0.65; Japanese flounder, $0.6 \mathrm{P} / 100 \mathrm{~g}$ diet. Obviously, there is a need to better define the P requirements of fish taking into account the stage of development, bioavailability of $\mathrm{P}$ from the test diet and feed supplement used to fortify the experimental diets. Studies conducted on other animals show that the maximum growth rates are not necessarily adequate for maximum bone mineralization and they may need higher levels of P in their diet [407].

\subsubsection{Deficiency}

Calcium deficiency has not been detected in carp and catfish in FW [367,380] or in Atlantic salmon in SW [225] fed low-Ca diets. Generally, uptake of Ca from water and absorption from dietary feed ingredients supplies sufficient calcium to meet the requirements of most finfish. Studies conducted on the $\mathrm{P}$ requirements of several fish species have shown reduced weight gain, feed utilization and bone mineralization when the P contents of the diets were low, with certain exceptions: gibel carp [385,394], red 
drum [394], gilthead bream [396] and European seabass [400]. Other P deficiency signs experimentally produced in fish included increases in liver or body fat, reduced blood phosphate levels and poor mineralization of scales. Fish fed either a mineral-deficient or low-P diet mobilize minerals including $\mathrm{Ca}$ and $\mathrm{P}$ to maintain normal physiological functions [96] and fish scales appear to be the most sensitive indicator of P deficiency in young fish $[376,408]$. The causes of low dietary P-induced skeletal deformities in salmonids and certain marine fish have been the subject of intensive research and several reviews have been published in this area [30,409-411]. Common skeletal deformities with low intake of $P$ include curved spines and soft bones in Atlantic salmon [411], cephalic deformities in the frontal bones of common carp [367] and compressed vertebral bodies resulting in scoliosis in haddock [398] and halibut [410]. Recent studies of bone matrix mineralization in Atlantic salmon have revealed mobilization of minerals during low intake of dietary $\mathrm{P}$ and that the normal growth of non-mineralized bone does not fully explain the biochemical mechanism involved in bone P metabolism [412-415]. Several nutrients support skeletal growth including bone and scale matrix mineralization and the interactions between $\mathrm{P}$ and other nutrients in skeletal tissue biomineralization are poorly understood [30].

\subsubsection{Bioavailability}

The bioavailability of $\mathrm{P}$ to fish differs markedly among feed ingredients and inorganic $\mathrm{P}$ supplements as well as among other dietary factors (e.g., chemical form, digestibility of diet, particle size, interaction with other nutrients, feed processing and water chemistry) $[3,416]$. Most of the $\mathrm{P}$ in cereal grains and oilseed meals present in the form of an organic complex, phytic acid or phytate (myo-inositol 1, 2, 3, 4, 5, 6-hexakis dihydrogen phosphate) is not available to fish because their intestinal tract does not have sufficient extracellular phytase like other nonruminant vertebrates. Phytate depresses protein and amino acid digestibility and utilization efficiency in fish and other higher animals. Phytate interactions with proteins are also $\mathrm{pH}$ dependent [417]. Several reviews have considered various aspects of phytates in fish nutrition and potential strategies to improve the bioavailability of phytates in feed ingredients of plant origin [271,418-420]. The hydrolysis of phytic acid can be achieved by enzymatic and nonenzymatic degradation. Development of phytases and optimization of their catalytic features has been a promising strategy for efficient reduction of phytate in animal feeds. Phytate also forms complexes with lipid and derivatives along with other nutrients [421] but this aspect of chelate formation has not been investigated in fish. The preferable method of phytase application in feeds is coating a liquid form of the enzyme after extrusion and drying which prevents loss of enzyme activity during processing [422].

Phosphorus in fish meal is mainly in the form of an insoluble Ca-P complex, hydroxyapatite, which varies with the source of fish used and its bioavailability varies among fish species [2,3]. Acid hydrolysis of fish bone by-products appears to increase P availability of the hydroxyapatite in bone [423]. There are significant differences in the availability of $P$ from a variety of inorganic salts: the more soluble the salt, the higher the availability of $\mathrm{P}$, thus $\mathrm{P}$ is more readily available from mono- or di-calcium phosphates than from tri-calcium phosphate [2,3]. Salmonids utilize $P$ present in fish meal more efficiently than carp, tilapia and channel catfish [370,424-426].

\subsection{Magnesium}

Magnesium is a critical intracellular divalent cation that plays an essential physiological role in many functions in the body. It forms a key complex with ATP and plays a key role in many important biological processes such as protein synthesis, cell replication and energy metabolism. Magnesium is a regulator of ion channels, an important intracellular signaling molecule, involved in nerve conduction, muscle contraction and potassium transport, and is a modulator of oxidative phosphorylation. Extracellular Mg is vital to normal nerve conduction, muscle function and skeletal tissue metabolism. It plays an important role in the respiratory adaptation of FW fish [427]. The major proportion (50-70\%) of $\mathrm{Mg}$ in the body of fish is located in skeletal tissues and scales [428]. The remainder is found 
within the cells of soft tissues. In muscle, it comprises approximately $20 \%$ of the total body Mg pool [137].

Dietary Mg is considered the main source for growth and development of fish [6,429]. When dietary Mg concentration was low in FW, part of its requirement was met by uptake from water via the gills $[430,431]$. However, in most fish species studied, Mg uptake from FW was insufficient to meet their dietary Mg requirement $[3,6]$. There is some evidence that excess $\mathrm{Mg}$ is excreted renally by fish in FW [432]. In SW, fish absorb Mg by drinking [433] and the major part of the $\mathrm{Mg}$ requirement of Atlantic salmon and other marine fish could be met by absorption of SW [225].

\subsubsection{Requirement}

The magnesium requirements of most farmed fish species range from 0.4 to $0.6 \mathrm{~g} \mathrm{~kg}^{-1}$ diet $[3,6,96]$. Hybrid tilapia showed Mg requirements of 0.2 and $0.02 \%$ in FW and SW, respectively. No requirement of $\mathrm{Mg}$ for yellow croaker and red mullet has been reported [434]. A meta-analysis of $\mathrm{Mg}$ requirements reported for several fish species showed relatively close estimates for the $\mathrm{Mg}$ requirement $\left(\mathrm{g} \mathrm{kg}^{-1}\right.$ diet) based on the following parameters: weight gain, 0.34; whole body $\mathrm{Mg}, 0.49$; vertebrae $\mathrm{Mg}$, 0.42 ; plasma $\mathrm{Mg}$, 0.5 [105]. In SW, $\mathrm{Mg}$ requirement for Atlantic salmon and red seabream was not observed [225,435]. Unlike terrestrial animals, the $\mathrm{Mg}$ requirement of rainbow trout was not influenced by an increase in dietary Ca and P levels [137].

\subsubsection{Deficiency}

Magnesium is mobilized from bones and scales when dietary Mg intake is low [429]. Deficiency of Mg in carp, catfish, hybrid tilapia, eel and rainbow trout may include one or more of the following signs: anorexia, reduced growth, sluggishness, high mortality and reduced magnesium content $[3,30]$. In rainbow trout, $\mathrm{Mg}$ deficiency also causes calcinosis of the kidney, vertebral deformity and degeneration of muscle fibers and epithelial cells of the pyloric cecum and gill filaments [429,436]. A low concentration of $\mathrm{Mg}$ in water reduced the Mn concentration of eggs in carp, which reduced the hatchability of eggs and survival of offspring and also caused deformities and tissue necrosis [437].

\subsubsection{Bioavailability}

Information on $\mathrm{Mg}$ bioavailability from feed ingredients and inorganic supplements for fish is scarce. Generally, natural feed ingredients of plant and animal origin contain moderate levels of $\mathrm{Mg}$. Inorganic $\mathrm{Mg}$ feed supplements include magnesium sulfate, magnesium chloride, magnesium oxide and magnesium acetate. Magnesium sulfate is more water soluble than magnesium oxide and therefore more available for absorption. Magnesium present as $\mathrm{Mg}$ acetate was more efficiently used by tilapia than either Mg oxide or sulfate [438].

\section{Concluding Remarks}

Many gaps exist in the knowledge of mineral nutrition of fish and shrimp related to their dietary requirements, physiological functions, absorption from the gastrointestinal tract and bioavailability from feed ingredients. Information on animal and human nutrition has been useful to confirm the biochemical functions of certain inorganic elements including skeletal tissue metabolism, cellular respiration, oxygen transport and regulation of acidbase equilibrium as well as important components of hormones, enzymes and enzyme activators. Extensive research on farm animals has demonstrated that mineral requirements differ at various stages of their production cycle, certain trace elements play important roles in immune functions and disease prevention and application of specific methodologies are useful to predict the bioavailability of minerals from feed ingredients; however, the research in these areas on fish is limited. Another issue specific to aquatic animals is that there is a need to consider the impact of waterborne minerals from both the nutritional and environmental points of view. 
Aquaculture is now the fastest growing food production system globally with many new challenges to address the nutritional problems of more than 40 major farmed fish species. Early studies on mineral nutrition were conducted on salmonids and some warm water fishes using semi-purified diets and trace element supplements of high bioavailability. Most known mineral requirements ( $\mathrm{Ca}, \mathrm{P}, \mathrm{Mg}, \mathrm{Cu}, \mathrm{Zn}, \mathrm{Mn}$, Se) were determined for young fish. The NRC $[2,3]$ requirement values for certain minerals for about 10 fish species have been used as guidelines and as a starting point to establish recommendation allowances for new fish species. Many studies were short term and gave little consideration to the dietary intake or mineral status prior to the experimental period and to the effect that the previous diet may have on body stores at the commencement of the study. Some minerals take longer, depending on the water temperature, to reach a steady state following a change in their dietary intake. A shift from the use of fish meal as a major source of protein and minerals in feeds to proteins of plant origin and land animal products now requires better assessment of mineral bioavailability for improving feed formulation more precisely. There are also new trace element supplements available which require proper assessment of their rate of absorption and potential impact on fish performance.

As an animal's requirement for any nutrient is affected by many factors, limited data on nutrient requirement values (e.g., NRC [3]) should not be regarded as fixed quantities. Instead of solely relying on these values, changes in animal performance with alterations in nutrient intake should be determined as dynamic responses, to derive requirement estimates that are appropriate to the particular fish species under different culture conditions and dietary regimes. This should start with the units of expression of data on mineral requirements. Meta-analyses of existing data on requirements provide some general guidelines on recommendations. Factorial models are now being applied to estimate nutrient requirements and metabolism of farmed animals and fish; however, additional reliable new data on mineral requirements of major farmed fish species are needed to generate reliable information for use in feed formulation.

Author Contributions: Conceptualization, S.P.L., S.J.K.; original draft preparation S.P.L., S.J.K.; visualization, S.P.L., S.J.K. All authors have read and agreed to the published version of the manuscript.

Funding: This research received no external funding.

Institutional Review Board Statement: Not applicable.

Data Availability Statement: Not applicable.

Conflicts of Interest: The authors declare no conflict of interest.

\section{References}

1. Suttle, N. Mineral Nutrition of Livestock, 4th ed.; Commonwealth Agricultural Bureaux International: Oxfordshire, UK, 2010; p. 579.

2. National Research Council. Nutrient Requirements of Fish; The National Academies Press: Washington, DC, USA, 1993.

3. National Research Council. Nutrient Requirements of Fish and Shrimp; The National Academies Press: Washington, DC, USA, 2011.

4. Wood, C.M.; Farrell, A.M.; Brauner, C.J. Homeostasis and Toxicology of Essential Metals; Elsevier/Academic Press: Cambridge, MA, USA, 2012; Volume 31A, p. 495.

5. Wood, C.M.; Farrell, A.M.; Brauner, C.J. Homeostasis and Toxicology of Non-Essential Metals; Elsevier/Academic Press: Cambridge, MA, USA, 2012; Volume 31B, p. 531.

6. Lall, S.P. The minerals. In Fish Nutrition, 3rd ed.; Halver, J.E., Hardy, R.W., Eds.; Elsevier/Academic Press: San Diego, CA, USA, 2002; pp. 259-308.

7. Evans, D.H.; Claiborne, J.B. Osmotic and ionic regulation in fishes. In Osmotic and Ionic regulation: Cells and Animals; Evans, D.H., Ed.; CRC Press: Boca Raton, FL, USA, 2009; pp. 295-366.

8. Tacon, A.G.J.; Metian, M.; McNevin, A.A. Future Feeds: Suggested guidelines for sustainable development. Rev. Fish Sci. 2021. [CrossRef]

9. O'Dell, B.L. Mineral-ion interaction as assessed by bioavailability and ion-channel function. In Handbook of Nutritionally Essential Elements; O’Dell, B.L., Sunde, R.A., Eds.; Marcel Dekker Inc.: New York, NY, USA, 1997; pp. 641-659.

10. Erdman, J.W., Jr. Oilseeds phytates: Nutritional implications. J. Am. Oil Chem. Soc. 1979, 66, 736-741. [CrossRef]

11. Hilton, J.W. The interaction of vitamins, minerals and diet composition in the diet of fish. Aquaculture 1989, 79, 223-244. [CrossRef]

12. Ammerman, C.B. Methods for estimation of mineral bioavailability. In Bioavailability of Nutrients for Animals: Amino Acids, Minerals and Vitamins; Ammerman, C.B., Baker, D.J., Lewis, A.J., Eds.; Elsevier/Academic Press: San Diego, CA, USA, 1995; pp. 83-94. 
13. Spears, J.W.; Hansen, S.L. Bioavailability criteria for trace minerals in monogastric and ruminants. In Trace Elements in Animal Production Systems; Schlegel, P., Durosoy, S., Jongbloed, A.W., Eds.; Wageningen Academic Publishers: Wageningen, The Netherlands, 2008; pp. 161-170.

14. Bury, N.R.; Walker, P.A.; Glover, C.N. Nutritive metal uptake in teleost fish. J. Exp. Biol. 2003, 206, 11-23. [CrossRef]

15. Wood, C.M. An introduction to metals in fish physiology and toxicology: Basic principles. In Fish physiology: Homeostasis and Toxicology of Essential Metals; Wood, C.M., Farrell, A.M., Brauner, C.J., Eds.; Elsevier/Academic Press: Cambridge, MA, USA, 2012; pp. 1-53.

16. Brix, K.V.; Tellis, M.S.; Crémazy, A.; Wood, C.M. Characterization of the effects of binary metal mixtures on short-term uptake of $\mathrm{Cd}, \mathrm{Pb}$, and $\mathrm{Zn}$ by rainbow trout (Oncorhynchus mykiss). Aquat. Toxicol. 2017, 193, 217-227. [CrossRef] [PubMed]

17. Grosell, M. Copper. In Fish Physiology: Homeostasis and Toxicology of Essential Metals; Wood, C.M., Farrell, A.M., Brauner, C.J., Eds.; Elsevier/Academic Press: Cambridge, MA, USA, 2012; Volume 31A, pp. 53-133.

18. Hogstrand, C. Zinc. In Fish Physiology: Homeostasis and Toxicology of Essential Metals; Wood, C.M., Farrell, A.M., Brauner, C.J., Eds.; Elsevier/Academic Press: Cambridge, MA, USA, 2012; Volume 31A, pp. 135-200.

19. Handy, R.D. Dietary exposure to trace metals in fish. In Toxicology of Aquatic Pollution; Taylor, E.W., Ed.; Cambridge University Press: Cambridge, MA, USA, 1996; pp. 29-60.

20. Lall, S.P.; Milley, J.E. Impact of aquaculture on aquatic environment: Trace minerals discharge. In Trace Elements in Animal Production Systems; Schlegel, P., Durosoy, S., Jongbloed, A.W., Eds.; Wageningen Academic Publishers: Wageningen, The Netherlands, 2008; pp. 77-87.

21. Dean, R.J.; Shimmield, T.M.; Black, K.D. Copper, zinc and cadmium in marine cage fish farm sediments: An extensive survey. Environ. Pollut. 2007, 145, 84-95. [CrossRef] [PubMed]

22. Brooks, K.M.; Stierns, A.R.; Mahnken, C.V.W.; Blackburn, D.B. Chemical and biological remediation of the benthos near Atlantic salmon farms. Aquaculture 2003, 219, 355-377. [CrossRef]

23. Petersen, W.; Wallman, K.; Pinglin, L.; Schroeder, F.; Knauth, H.D. Exchange of trace elements at the sediment-water interface during early diagenesis processes. Mar. Freshw. Res. 1995, 46, 19-26. [CrossRef]

24. Ponce, R.; Forja, J.M.; Gomez-Parra, A. Influence of anthropogenic activity on the vertical distribution of $\mathrm{Zn}, \mathrm{Cd}, \mathrm{Pb}$ and $\mathrm{Cu}$ in interstitial water and coastal marine sediments (Cadiz Bay, SW Spain). Cienc. Mar. 2000, 26, 479-502. [CrossRef]

25. McGeer, J.C.; Niyogi, S.; Scott Smith, D. Cadmium. In Homeostasis and Toxicology of Non-Essential Metals; Wood, C.M., Farrell, A.P., Brauner, C.J., Eds.; Elsevier/Academic Press: Cambridge, MA, USA, 2012; pp. 125-184.

26. Sundby, B.; Martinez, P.; Gobeil, C. Comparative geochemistry of cadmium, rhenium, uranium, and molybdenum in continental marine sediments. Geochim. Cosmochim. Acta. 2004, 68, 2485-2493. [CrossRef]

27. Mertz, W. Review of the scientific basis for establishing the essentiality of trace elements. Biol. Trace Elem. Res. 1998, 66, 185-191. [CrossRef] [PubMed]

28. Maret, W. Metalloproteomics, metalloproteomes, and the annotation of metalloproteins. Metallomics 2010, 2, 117-125. [CrossRef] [PubMed]

29. Andreini, C.; Bertini, I.; Rosato, A. Metalloproteomes: A bioinformatic approach. Acc. Chem. Res. 2009, 42, 1471-1479. [CrossRef] [PubMed]

30. Lall, S.P. Disorders of nutrition and metabolism. In Fish Diseases and Disorders; Leatherland, J.F., Woo, P.T.K., Eds.; CABI: Wallingford, UK, 2010; Volume 2, pp. 202-237.

31. Lehmann, I.; Sack, U.; Lehmann, J. Metal ions affecting the immune system. Met. Ions Life Sci. 2011, 8, 157-185.

32. Richards, J.D.; Zhao, J.; Harrell, C.A.; Atwell, A.; Dibner, J.J. Trace mineral nutrition in poultry and swine. Asian-Australas. J. Anim. Sci. 2010, 23, 1527-1534. [CrossRef]

33. Mohan, K.; Ravichandran, S.; Muralisankar, T.; Uthayakumar, V.; Chandirasekar, R.; Seedevi, P.; Abirami, R.G.; Rajan, D.K. Application of marine-derived polysaccharides as immunostimulants in aquaculture: A review of current knowledge and further perspectives. Fish Shellfish Immun. 2019, 86, 1177-1193. [CrossRef] [PubMed]

34. Linder, M.C. Biochemistry and molecular biology of copper in mammals. In Handbook of Copper Pharmacology and Toxicology; Massaro, E.J., Ed.; Humana Press Inc.: Totowa, NJ, USA, 2002; pp. 3-32.

35. Prohaska, J.R. Impact of copper limitation on expression and function of multicopper oxidases (ferroxidases). Adv. Nutr. 2011, 2, 89-95. [CrossRef]

36. Harris, E.D. Basic and clinical aspects of copper. Crit. Rev. Clin. Lab. Sci. 2003, 40, 547-586. [CrossRef]

37. Kamunde, C.; Grosell, M.; Higgs, D.; Wood, C.M. Copper metabolism in actively growing rainbow trout (Oncorhynchus mykiss): Interactions between dietary and waterborne copper uptake. J. Exp. Biol. 2002, 205, 279-290. [CrossRef] [PubMed]

38. Taylor, L.N.; Wood, C.M.; McDonald, D.G. An evaluation of sodium loss and gill metal binding properties in rainbow trout and yellow perch to explain species differences in copper tolerance. J. Exp. Biol. 2003, 22, 2159-2166. [CrossRef]

39. Miller, P.A.; Lanno, R.P.; McMaster, M.E.; Dixon, D.G. Relative contribution of dietary and waterborne copper to tissue copper burdens and waterborne copper uptake in rainbow trout (Oncorhynchus mykiss). Can. J. Fish. Aquat. Sci. 1993, 50, 1683-1689. [CrossRef]

40. McDonald, D.G.; Wood, C.M. Branchial mechanism of acclimation to metals in freshwater fish. Fish. Ecophysiol. Fish. Ser. 1993, 9 , 297-321. 
41. Grosell, M.; Wood, C.M. Copper uptake across rainbow trout gills: Mechanisms of apical entry. J. Exp. Biol. 2002, 205, 1179-1188. [CrossRef]

42. Clearwater, S.J.; Baskin, S.J.; Wood, C.M.; McDonald, D.G. Gastrointestinal uptake and distribution of copper in rainbow trout. J. Exp. Biol. 2000, 203, 2433-2466. [CrossRef]

43. Handy, R.D.; Musonda, M.M.; Phillips, C.; Falla, S.J. Mechanisms of gastrointestinal copper absorption in the African walking catfish: Copper dose-effects and a novel anion dependent pathway in the intestine. J. Exp. Biol. 2000, 203, 2365-2377. [CrossRef] [PubMed]

44. Eyckmans, M.; Celis, N.; Horemans, N.; Blust, R.; De Boeck, G. Exposure to waterborne copper reveals differences in oxidative stress response in three freshwater fish species. Aquat. Toxicol. 2011, 103, 112-120. [CrossRef] [PubMed]

45. Cousins, R.J. Absorption, transport, and hepatic metabolism of copper and zinc: Special reference to metallothionein and ceruloplasmin. Physiol. Rev. 1985, 65, 238-309. [CrossRef] [PubMed]

46. Grosell, M.; Boëtius, I.; Hansen, H.J.; Rosenkilde, P. Influence of preexposure to sublethal levels of copper on 64Cu uptake and distribution among tissues of the European eel (Anguilla anguilla). Comp. Biochem. Physiol. Part C Pharmacol. Toxicol. Endocrinol. 1996, 114, 229-235. [CrossRef]

47. National Research Council. Mineral. Tolerance of Animals; The National Academies Press: Washington, DC, USA, 2005.

48. Song, J.; Li, L.-Y.; Chen, B.-B.; Shan, L.-L.; Yuan, S.-Y.; Yu, H.-R. Dietary copper requirements of postlarval coho salmon (Oncorhynchus kisutch). Aquac. Nutr. 2021, 1-9. [CrossRef]

49. Knox, D.; Cowey, C.B.; Adron, J.W. Effects of dietary copper and copper: Zinc ratio on rainbow trout (Salmo gairdneri). Aquaculture 1982, 27, 111-119. [CrossRef]

50. Lorentzen, M.; Maage, A.; Julshamn, K. Supplementing copper to a fish meal based diet fed to Atlantic salmon parr affects liver copper and selenium concentrations. Aquac. Nutr. 1998, 4, 67-72. [CrossRef]

51. Andersen, F.; Maage, A.; Julshamn, K. An estimation of iron requirement of Atlantic salmon Salmo salar L., parr. Aquac. Nutr. 1996, 2, 41-47. [CrossRef]

52. Naser, N. Role of Iron in Atlantic Salmon (Salmo salar) Nutrition: Requirement, Bioavailability, Disease Resistance and Immune Response. Ph.D. Thesis, Dalhousie University, Halifax, UK, 2000.

53. Ogino, C.; Yang, G.Y. Requirements of carp and rainbow trout for dietary manganese and copper. Bull. Jpn. Soc. Sci. Fish. 1980, 46, 455-458. [CrossRef]

54. Gatlin, D.M., III; Wilson, R.P. Dietary copper requirement of fingerling channel catfish. Aquaculture 1986, 54, 277-285. [CrossRef]

55. Gatlin, D.M., III; Wilson, R.P. Characterization of iron deficiency and the dietary iron requirement of fingerling channel catfish. Aquaculture 1986, 52, 191-198. [CrossRef]

56. Tan, X.Y.; Luo, Z.; Liu, X.; Xie, C.X. Dietary copper requirement of juvenile yellow catfish Pelteobagrus fulvidraco. Aquac. Nutr. 2011, 17, 170-176. [CrossRef]

57. Luo, Z.; Zou, G.Y.; Gao, Y.; Ye, H.M.; Xi, W.Q.; Liu, X. Effect of dietary iron (Fe) levels on growth performance, hepatic lipid metabolism and antioxidant responses in juvenile yellow catfish Pelteobagrus fulvidraco. Aquac. Nutr. 2017, 23, 1475-1482. [CrossRef]

58. Ling, J.; Feng, L.; Liu, Y.; Jiang, J.; Jiang, W.D.; Hu, K.; Li, S.H.; Zhou, X.Q. Effect of dietary iron level on growth, body composition and intestinal enzyme activities of juvenile Jian carp (Cyprinus carpio Var Jian). Aquac. Nutr. 2010, 16, 616-624. [CrossRef]

59. Pan, L.; Xie, S.; Lei, W.; Han, D.; Yang, Y. The effect of different dietary iron levels on growth and hepatic iron concentration in juvenile gibel carp (Carassius auratus gibelio). J. Appl. Ichthyol. 2009, 25, 428-431. [CrossRef]

60. Tang, Q.Q.; Feng, L.; Jiang, W.D.; Liu, Y.; Jiang, J.; Li, S.H.; Kuang, S.Y.; Tang, L.; Zhu, X.Q. Effects of dietary copper on growth, digestive, and brush border enzyme activities and antioxidant defense of hepatopancreas and intestine for young grass carp (Ctenopharyngodon idella). Biol. Trace Elem. Res. 2013, 155, 370-380. [CrossRef] [PubMed]

61. Shiau, S.; Ning, Y. Estimation of dietary copper requirements of juvenile tilapia, Oreochromis niloticus $\times$ O. aureus. Anim. Sci. 2003, 77, 287-292. [CrossRef]

62. Shiau, S.Y.; Su, L.W. Ferric citrate is half as effective as ferrous sulfate in meeting the iron requirement of juvenile tilapia, Oreochromis niloticus $\times$ O. aureus. J. Nutr. 2003, 133, 483-488. [CrossRef] [PubMed]

63. Nose, T.; Arai, S. Recent advances on studies on mineral nutrition of fish in Japan. In Advances in Aquaculture; Pillay, V.R., Dill, W.A., Eds.; Fishing News: Farnam, UK, 1979; pp. 584-590.

64. Zafar, N.; Khan, M.A. Determination of dietary phosphorus requirement of stinging catfish Heteropneustes fossilis based on feed conversion, growth, vertebrae phosphorus, whole body phosphorus, haematology and antioxidant status. Aquac. Nutr. 2018, 24, 1577-1586. [CrossRef]

65. Wang, H.; Li, E.; Zhu, H.; Du, Z.; Qin, J.; Chen, L. Dietary copper requirement of juvenile Russian sturgeon Acipenser gueldenstaedtii. Aquaculture 2016, 454, 118-124. [CrossRef]

66. Sakamoto, S.; Yone, Y. Requirement of red sea bream for dietary iron II. Bull. Jpn. Soc. Sci. Fish. 1978, 44, 223-225. [CrossRef]

67. Wang, Q.; Zhang, Y.; Bai, D.; Chen, C.; Guo, Y.; Xing, K. Estimation of dietary copper (Cu) requirement of Cynoglossus semilaevis Günther. In Advances in Applied Biotechnology (Proceedings of the 2nd International Conference on Applied Biotechnology); Zhang, T.C., Nakajima, M., Eds.; Springer: Berlin/Heidelberg, Germany, 2015; Volume 332.

68. Lin, Y.-H.; Shie, Y.-Y.; Shiau, S.-Y. Dietary copper requirements of juvenile grouper, Epinephelus malabaricus. Aquaculture 2008, 274, 161-165. [CrossRef] 
69. Ye, C.X.; Liu, Y.J.; Mai, K.S.; Tian, L.X.; Yang, H.J.; Niu, J.; Huang, J.W. Effect of dietary iron supplement on growth, haematology and microelements of juvenile grouper, Epinephelus coioides. Aquac. Nutr. 2007, 13, 471-477. [CrossRef]

70. Lin, Y.H.; Shih, C.C.; Kent, M.; Shiau, S.-Y. Dietary copper requirement re-evaluation for juvenile grouper, Epinephelus malabaricus, with an organic copper source. Aquaculture 2010, 310, 173-177. [CrossRef]

71. Cao, J.; Miao, X.; Xu, W.; Li, J.; Zhang, W.; Mai, K. Dietary copper requirements of juvenile large yellow croaker Larimichthys croceus. Aquaculture 2014, 432, 346-350. [CrossRef]

72. Qiao, Y.G.; Mai, K.S.; Ai, Q.H.; Zhang, W.D.; Xu, W. Evaluation of iron methionine and iron sulphate as dietary iron sources for juvenile cobia (Rachycentron canadum). Aquac. Nutr. 2013, 19, 721-730. [CrossRef]

73. Satoh, S.; Yamamoto, H.; Takeuchi, T.; Watanabe, T. Effects on growth and mineral composition of carp of deletion of trace elements or magnesium from fish meal diet. Nippon Suisan Gakkaishi 1983, 49, 431-435. [CrossRef]

74. Jezierska, B.; Ługowska, K.; Witeska, M. The effects of heavy metals on embryonic development of fish: A review. Fish Physiol. Biochem. 2009, 35, 625-640. [CrossRef] [PubMed]

75. Johnson, A.; Carew, E.; Sloman, K.A. The effects of copper on the morphological and functional development of zebrafish embryos. Aquat. Toxicol. 2007, 84, 431-438. [CrossRef] [PubMed]

76. Lanno, R.P.; Slinger, S.J.; Hilton, J.W. Maximum tolerable and toxicity levels of dietary copper in rainbow trout (Salmo gairdneri R). Aquaculture 1985, 49, 257-268. [CrossRef]

77. Baker, R.T.M. Chronic dietary exposure to copper affects growth, tissue lipid peroxidation, and metal composition of the grey mullet, Chelon labrosus. Mar. Environ. Res. 1998, 45, 357-365. [CrossRef]

78. Berntssen, M.H.G.; Waagbø, R.; Toften, H.; Lundebye, A.K. Effects of dietary cadmium on calcium homeostasis, Ca mobilization and bone deformities in Atlantic salmon (Salmo salar L.) parr. Aquac. Nutr. 1999, 9, 175-183. [CrossRef]

79. Berntssen, M.H.G.; Lundebye, A.K.; Maage, A. Effects of elevated dietary copper concentrations on growth, feed utilisation and nutritional status of Atlantic salmon (Salmo salar L.) fry. Aquaculture 1999, 174, 167-181. [CrossRef]

80. Clearwater, S.J.; Farag, A.; Meyer, J. Bioavailability and toxicity of diet borne copper and zinc to fish. Comp. Biochem. Physiol. Part C 2002, 132, 269-313.

81. Hansen, J.A.; Lipton, J.; Welsh, P.G.; Cacela, D.; MacConnell, B. Reduced growth of rainbow trout (Oncorhynchus mykiss) fed a live invertebrate diet pre-exposed to metal-contaminated sediments. Environ. Toxicol. Chem. 2004, 23, 1902-1911. [CrossRef]

82. Kim, S.G.; Kang, J.C. Effect of dietary copper exposure on accumulation, growth and hematological parameters of the juvenile rockfish, Sebastes schlegeli. Mar. Environ. Res. 2004, 58, 65-82. [CrossRef]

83. Kang, J.C.; Kim, S.G.; Jang, S.W. Growth and hematological changes of rockfish, Sebastes schlegeli (Hilgendorf) exposed to dietary $\mathrm{Cu}$ and Cd. J. World Aquac. Soc. 2005, 36, 188-195. [CrossRef]

84. Shaw, B.J.; Handy, R.D. Dietary copper exposure and recovery in Nile tilapia, Oreochromis niloticus. Aquat. Toxicol. 2006, 76, 111-121. [CrossRef] [PubMed]

85. Hoyle, I.; Shaw, B.J.; Handy, R.D. Dietary copper exposure in the African walking catfish, Clarias gariepinus: Transient osmoregulatory disturbances and oxidative stress. Aquat. Toxicol. 2007, 83, 62-72. [CrossRef] [PubMed]

86. Damasceno, F.M.; Fleuri, L.F.; Sartori, M.M.P.; Amorim, R.L.; Pezzato, L.E.; da Silva, R.L.; Carvalho, P.L.; Barros, M.M. Effect of dietary inorganic copper on growth performance and hematological profile of Nile tilapia subjected to heat-induced stress. Aquaculture 2016, 454, 257-264. [CrossRef]

87. Berntssen, M.H.G.; Lundebye, A.K.; Hamre, K. Tissue lipid peroxidative responses in Atlantic salmon (Salmo salar L.) parr fed high levels of dietary copper and cadmium. Fish Physiol. Biochem. 2000, 21, 35-48. [CrossRef]

88. EFSA. Scientific opinion on the revision of the currently authorised maximum copper content in complete feed. EFSA J. 2016, 14, 100. [CrossRef]

89. Pagenkopf, G.K. Gill surface interaction model for trace-metal toxicity to fishes: Role of complexation, $\mathrm{pH}$, and water hardness Environ. Sci. Technol. 1983, 17, 342-347. [CrossRef]

90. Niyogi, S.; Wood, C.M. Biotic ligand model, a flexible tool for developing site-specific water quality guidelines for metals. Environ. Sci. Technol. 2004, 38, 6177-6192. [CrossRef]

91. Beaumont, M. Exposure of brown trout, Salmo trutta, to a sub-lethal concentration of copper in soft acidic water: Effects upon muscle metabolism and membrane potential. Aquat. Toxicol. 2000, 51, 259-272. [CrossRef]

92. Domínguez, D.; Rimoldi, S.; Robaina, L.E.; Torrecillas, S.; Terova, G.; Zamorano, M.J.; Karalazos, V.; Hamre, K.; Izquierdo, M. Inorganic, organic, and encapsulated minerals in vegetable meal based diets for Sparus aurata (Linnaeus, 1758). Peer. J. 2017, 5, e3710. [CrossRef]

93. Kjoss, V.A.; Wood, C.M.; McDonald, D.G. Effects of different ligands on the bioaccumulation and subsequent depuration of Cu and $\mathrm{Zn}$ in juvenile rainbow trout Oncorhynchus mykiss. Can. J. Fish. Aquat. Sci. 2006, 63, 412-422. [CrossRef]

94. Baker, D.J.; Ammerman, C.B. Copper bioavailability. In Bioavailability of Nutrients for Animals: Amino Acids, Minerals and Vitamins; Ammerman, C.B., Baker, D.J., Lewis, A.J., Eds.; Elsevier/Academic Press: San Diego, CA, USA, 1995; pp. 127-156.

95. Read, E.S.; Barrows, F.T.; Gaylord, T.G.; Paterson, J.; Petersen, M.K.; Sealey, W.M. Investigation of the effects of dietary protein source on copper and zinc bioavailability in fishmeal and plant-based diets for rainbow trout. Aquaculture 2014, 432, 97-105. [CrossRef]

96. Lall, S.P. The Minerals. In Fish Nutrition, 4th ed.; Hardy, R.W., Ed.; Elsevier/Academic Press: San Diego, CA, USA, 2021. 
97. Glover, C.N.; Hogstrand, C. Amino acid modulation of in vivo intestinal zinc uptake in freshwater rainbow trout. J. Exp. Biol. 2002, 205, 151-158. [CrossRef]

98. Andersen, F.; Lorentzen, M.; Waagbø, R.; Maage, A. Bioavailability and interactions with other micronutrients of three dietary iron sources in Atlantic salmon, Salmo salar, smolts. Aquac. Nutr. 1997, 3, 239-246. [CrossRef]

99. Cooper, C.A.; Bury, N.R. The gills as an important uptake route for the essential nutrient iron in freshwater rainbow trout Oncorhynchus mykiss. J. Fish Biol. 2007, 71, 115-128. [CrossRef]

100. Whitehead, M.W.; Thompson, R.P.H.; Powell, J.J. Regulation of metal absorption in the gastrointestinal tract. Gut 1996, 39, 625-628. [CrossRef]

101. Bury, N.; Grosell, M. Iron acquisition by teleost fish. Comp. Biochem. Physiol. Part C 2003, 135, 97-105. [CrossRef]

102. Bury, N.R.; Boyle, D.; Cooper, C.A. Iron. In Homeostasis and Toxicology of Essential Metals; Wood, C.M., Farrell, A.P., Brauner, C.J., Eds.; Fish Physiology; Academic Press: Cambridge, MA, USA, 2012; Volume 31A, pp. 201-251.

103. Glover, C.N.; Hogstrand, C. Effects of dissolved metals and other hydrominerals on in vivo intestinal zinc uptake in freshwater rainbow trout. Aquat. Toxicol. 2003, 62, 281-293. [CrossRef]

104. Wilson, R.W.; Wilson, J.M.; Grosell, M. Intestinal bicarbonate secretion by marine teleost fish-why and how? Biochim. Biophys. Acta 2002, 1566, 182-193. [CrossRef]

105. Antony Jesu Prabhu, P.; Schrama, J.W.; Kaushik, S.J. Mineral requirements of fish: A systematic review. Rev. Aquac. 2016, 8, 172-219. [CrossRef]

106. Kawatsu, H. Studies on the anemia of fish. 5. Dietary iron deficient anemia in brook trout (Salvelinus fontinalis). Bull. Freshw. Fish. Res. Lab. 1972, 22, 59-67.

107. Desjardins, L.M.; Hicks, B.D.; Hilton, J.W. Iron catalysed oxidation of trout diets and its effect on growth and physiological response of rainbow trout. Fish Physiol. Biochem. 1987, 3, 173-182. [CrossRef] [PubMed]

108. Bjørnevik, M.; Maage, A. Effects of dietary iron supplementation on tissue iron concentration and haematology in Atlantic salmon (Salmo salar). Fisk. Dir. Skr. Ser. Ernaer. 1993, 6, 35-45.

109. Sakamoto, S.; Yone, Y. Requirement of red sea bream for dietary Fe. Rep. Fish. Res. Lab. Kyushu Univ. 1976, 3, 53-58.

110. Ikeda, Y.; Ozaki, H.; Vematsu, K. Effect of enriched diet with iron in culture of yellow-tail. J. Tokyo Univ. Fish. 1973, 59, 91-99.

111. Dalzell, D.J.B.; MacFarlane, N.A.A. The toxicity of iron to brown trout and effects on the gills: A comparison of two grades of iron sulphate. J. Fish Biol. 1999, 55, 301-315. [CrossRef]

112. Henry, P.R.; Miller, E.R. Iron bioavailability. In Bioavailability of Nutrients for Animal: Amino Acids, Minerals, and Vitamins; Elsevier/Academic Press: Cambridge, MA, USA, 1995; pp. 169-199.

113. Sakamoto, S.; Yone, Y. Availabilities of three iron compounds as dietary iron sources for red sea bream. Bull. Jpn. Soc. Sci. Fish. 1979, 45, 231-235. [CrossRef]

114. Huang, Q.C.; Kwaku, A.; Wang, E.L.; Dong, X.H. Iron bioavailability of different sources in juvenile grouper Epinephelus coioides. Aquac. Res. 2018, 49, 2799-2807. [CrossRef]

115. Aschner, J.L.; Aschner, M. Nutritional aspects of manganese homeostasis. Mol. Asp. Med. 2005, 26, 353-362. [CrossRef]

116. Leach, R.M.; Harris, E.D.; O’Dell, B.L.; Sunde, R.A.E.; Dekker, M. Manganese. In Handbook of Nutritionally Essential Minerals; Marcel Dekker Inc.: New York, NY, USA, 1997; pp. 335-355.

117. Keen, C.L.; Ensunsa, J.L.; Clegg, M.S. Manganese metabolism in animals and humans including the toxicity of manganese. Met. Ions Biol. Syst. 1999, 37, 89-121.

118. Antony Jesu Prabhu, P.; Silva, M.S.; Kröeckel, S.; Holme, M.; Ørnsrud, R.; Amlund, H.; Erik-Jan Lock, E.J.; Waagbø, R. Effect of levels and sources of dietary manganese on growth and mineral composition of post-smolt Atlantic salmon fed low fish meal, plant-based ingredients. Aquaculture 2019, 512, 734287. [CrossRef]

119. Miller, D.W.; Vetter, R.J.; Atchison, G.J. Effect of temperature and dissolved oxygen on uptake and retention of $54 \mathrm{Mn}$ in fish. Health Phys. 1980, 38, 221-225. [PubMed]

120. Rouleau, C.; Tjalve, H.; Gottofrey, J.; Pelletier, E. Uptake, distribution, and elimination of ${ }^{54} \mathrm{Mn}(\mathrm{II})$ in brown trout (Salmo trutta). Environ. Toxicol. Chem. 1995, 14, 483-490. [CrossRef]

121. Peters, A.; Lofts, S.; Merrington, G.; Brown, B.; Stubblefield, W.; Harlow, K. Development of biotic ligand models for chronic manganese toxicity to fish, invertebrates, and algae. Environ. Toxicol. Chem. 2011, 30, 2407-2415. [CrossRef] [PubMed]

122. Partridge, G.J.; Lymbery, A.J. The effect of salinity on the requirement for potassium by barramundi (Lates calcarifer) in saline groundwater. Aquaculture 2008, 278, 164-170. [CrossRef]

123. Ye, C.X.; Tian, L.X.; Yang, H.J.; Liang, J.J.; Niu, J.; Liu, Y.J. Growth performance and tissue mineral content of juvenile grouper (Epinephelus coioides) fed diets supplemented with various levels of manganese. Aquac. Nutr. 2009, 15, 608-614. [CrossRef]

124. Vieira, M.C.; Torronteras, R.; Córdoba, F.; Canalejo, A. Acute toxicity of manganese in goldfish Carassius auratus is associated with oxidative stress and organ specific antioxidant responses. Ecotox. Environ. Saf. 2012, 78, 212-217. [CrossRef] [PubMed]

125. Nie, J.Q.; Dong, X.H.; Tan, B.P.; Chi, S.Y.; Yang, Q.H.; Liu, H.Y.; Shuang, Z. Effects of dietary manganese sources and levels on growth performance, relative manganese bioavailability, antioxidant activities and tissue mineral content of juvenile cobia (Rachycentron canadum L). Aquac. Res. 2016, 47, 1402-1412. [CrossRef]

126. Takeuchi, T.; Watanabe, T.; Ogino, C.; Saito, M.; Nishimura, K.; Nose, T. Effects of low protein-high calorie diets and deletion of trace elements from a fish meal diet on reproduction of rainbow trout. Bull. Jpn. Soc. Sci. Fish. 1981, 47, 645-654. [CrossRef] 
127. Lorentzen, M.; Maage, A.; Julshamn, K. Manganese supplementation of a practical, fish meal based diet for Atlantic salmon parr. Aquac. Nutr. 1996, 2, 121-125. [CrossRef]

128. Maage, A.; Lygren, B.; El-Mowafi, A.F. Manganese requirement of Atlantic salmon (Salmo salar) fry. Fish. Sci. 2000, 66, 1-8. [CrossRef]

129. Gatlin, D.M., III; Wilson, R.P. Studies on the manganese requirement of fingerling channel catfish. Aquaculture 1984, 41, 85-92. [CrossRef]

130. Tan, X.Y.; Xie, P.; Luo, Z.; Lin, H.Z.; Zhao, Y.H.; Xi, W.Q. Dietary manganese requirement of juvenile yellow catfish Pelteobagrus fulvidraco, and effects on whole body mineral composition and hepatic intermediary metabolism. Aquaculture 2012, 326-329, 68-73. [CrossRef]

131. Pan, L.; Zhu, X.; Xie, S.; Lei, W.; Han, D.; Yang, Y. Effects of dietary manganese on growth and tissue manganese concentrations of juvenile gibel carp, Carassius auratus gibelio. Aquac. Nutr. 2008, 14, 459-463. [CrossRef]

132. Lin, Y.H.; Lin, S.M.; Shiau, S.Y. Dietary manganese requirements of juvenile tilapia, Oreochromis niloticus x O. aureus. Aquaculture 2008, 284, 207-210. [CrossRef]

133. Zhang, H.; Sun, R.; Xu, W.; Zhou, H.; Zhang, W.; Mai, K. Dietary manganese requirement of juvenile large yellow croaker Larimichthys crocea (Richardson, 1846). Aquaculture 2016, 450, 74-79. [CrossRef]

134. Liu, K.; Ai, Q.H.; Mai, K.S.; Zhang, W.B.; Zhang, L.; Zheng, S.X. Dietary manganese requirement for juvenile cobia, Rachycentron canadum L. Aquac. Nutr. 2012, 19, 461-467. [CrossRef]

135. Ishak, I.M.; Dollar, A.M. Studies on manganese uptake in Tilapia mossambica and Salmo gairdneri. I. Growth and survival of Tilapia mossambica in response to manganese. Hydrobiologia 1968, 31, 572-584. [CrossRef]

136. Yamamoto, H.; Satoh, S.; Takeuchi, T.; Watanabe, T. Effects on rainbow trout of deletion of manganese or trace elements from fish meal diet. Nippon Suisan Gakkaishi 1983, 49, 287-293. [CrossRef]

137. Knox, D.; Cowey, C.B.; Adron, J.W. Studies on the nutrition of salmonid fish. The magnesium requirement of rainbow trout (Salmo gairdneri). Br. J. Nutr. 1981, 45, 137-148. [CrossRef]

138. Horning, K.J.; Caito, S.W.; Tipps, K.G.; Bowman, A.B.; Aschner, M. Manganese Is Essential for Neuronal Health. Ann. Rev. Nutr. 2015, 35, 71-108. [CrossRef] [PubMed]

139. Watanabe, T.; Kiron, V.; Satoh, S. Trace minerals in fish nutrition. Aquaculture 1997, 151, 185-207. [CrossRef]

140. Satoh, S.; Takeuchi, T.; Watanabe, T. Availability to carp of manganese in white fish meal and of various manganese compounds. Nippon Suisan Gakkaishi 1987, 53, 825-832. [CrossRef]

141. Ma, R.; Hou, H.; Mai, K.; Bharadwaj, A.S.; Ji, F.; Zhang, W. Comparative study on the effects of chelated or inorganic manganese in diets containing tricalcium phosphate and phytate on the growth performance and physiological responses of turbot Scophthalmus maximus. Aquac. Nutr. 2015, 21, 780-787. [CrossRef]

142. Lall, S.P.; Milley, J.E. Trace mineral requirements of fish and crustaceans. In Trace Elements in Animal Production Systems; Schlegel, P., Durosoy, S., Jongbloed, A.W., Eds.; Wageningen Academic Publishers: Wageningen, The Netherlands, 2008 ; pp. $203-214$.

143. Antony Jesu Prabhu, P.; Fountoulaki, E.; Maas, R.; Heinsbroek, L.T.N.; Eding, E.H.; Kaushik, S.J.; Schrama, J.W. Dietary ingredient composition alters faecal characteristics and waste production in common carp reared in recirculation system. Aquaculture 2019, 512, 734357. [CrossRef]

144. EFSA. Scientific opinion on the safety and efficacy of manganese hydroxychloride as feed additive for all animal species. EFSA $J$. 2016, 14, 4474. [CrossRef]

145. Poston, H.A.; Combs, G.F.; Leibovitz, L. Vitamin E and selenium interrelations in the diet of Atlantic salmon (Salmo salar): Gross, histological and biochemical deficiency signs. J. Nutr. 1976, 106, 892-904. [CrossRef]

146. Hilton, J.W.; Hodson, P.V.; Slinger, S.J. The requirement and toxicity of selenium in rainbow trout (Salmo gairdneri). J. Nutr. 1980, 110, 2527-2535. [CrossRef]

147. Hodson, P.V.; Hilton, J.W. The nutritional requirements and toxicity to fish of dietary and waterborne selenium. Ecol. Bull. 1983, $35,335-340$.

148. Labunsky, V.M.; Hatfield, D.L.; Gladyshev, V.N. Selenoproteins: Molecular pathways and physiological roles. Physiol. Rev. 2014, 94, 739-777. [CrossRef]

149. Roman, M.; Jitaru, P.; Barbante, C. Selenium biochemistry and its role for human health. Metallomics 2014, 6, 25-54. [CrossRef] [PubMed]

150. Mariotti, M.; Ridge, P.G.; Zhang, Y.; Lobanov, A.V.; Pringle, T.H.; Guigo, R.; Hatfield, D.L.; Gladyshev, V.N. Composition and evolution of the vertebrate and mammalian selenoproteomes. PLoS ONE 2012, 7, 33066. [CrossRef] [PubMed]

151. Hesketh, J. Nutrigenomics and selenium: Gene expression patterns, physiological targets, and genetics. Ann. Rev. Nutr. 2008, 28, 157-177. [CrossRef] [PubMed]

152. Papp, L.V.; Lu, J.; Holmgren, A.; Khanna, K.K. From selenium to selenoproteins: Synthesis, identity, and their role in human health. Antioxid. Redox Signal. 2007, 9, 775-806. [CrossRef]

153. Arthur, J.R.; McKenzie, R.C.; Beckett, G.J. Selenium in the immune system. J. Nutr. 2003, 133, 1457-1459. [CrossRef]

154. Fairweather-Tait, S.J.; Bao, Y.; Broadley, M.R.; Collings, R.; Ford, D.; Hesketh, J.E.; Hurst, R. Selenium in Human Health and Disease. Antioxid. Redox Signal. 2011, 14, 1337-1383. [CrossRef]

155. Choi, Y.J.; Kim, N.N.; Shin, H.S.; Park, M.S.; Kil, G.S.; Choi, Y.C. Effects of waterborne selenium exposure on the antioxidant and immunological activity in the goldfish, Carassius auratus. Mol. Cell. Toxicol. 2013, 9, 365-373. [CrossRef] 
156. Khan, K.U.; Zuberi, A.; Fernandes, J.B.K.; Ullah, I.; Sarwar, H. An overview of the ongoing insights in selenium research and its role in fish nutrition and fish health. Fish Physiol. Biochem. 2017, 43, 1689-1705. [CrossRef]

157. Dalgaard, T.S.; Briens, M.; Engberg, R.M.; Lauridsen, C. The influence of selenium and selenoproteins on immune responses of poultry and pigs. Anim. Feed Sci. Tech. 2018, 258, 73-83. [CrossRef]

158. Janz, D.M. Selenium. In Fish Physiology: Homeostasis and Toxicology of Essential Metals; Wood, C.M., Farrell, A.M., Brauner, C.J., Eds.; Elsevier/Academic Press: Cambridge, MA, USA, 2012; pp. 329-374.

159. Janz, D.M.; DeForest, D.K.; Brooks, M.L.; Chapman, P.M.; Gilron, G.; Hoff, D.J.; Hoppkins, W.A.; McIntyre, D.O.; Mebane, C.A.; Palace, V.P.; et al. Selenium Toxicity to Aquatic Organisms. In Ecological Assessment of Selenium in the Aquatic Environment; Chapman, P.M., Adams, W.J., Brooks, M.L., Delos, C.G., Luoma, S.N., Maher, W.A., Ohlendorf, H.M., Presser, T.S., Shaw, D.P., Eds.; CRC Press: Boca Raton, FL, USA, 2019; pp. 141-231.

160. Burk, R.F.; Hill, K.E. Regulation of selenium metabolism and transport. Ann. Rev. Nutr. 2015, 35, 109-134. [CrossRef]

161. National Research Council. Nutrient Requirements of Swine; The National Academies Press: Washington, DC, USA, 2012.

162. Hosnedlova, B.; Kepinska, M.; Skalickova, S.; Fernandez, C.; Ruttkay-Nedecky, B.; Malevu, T.D.; Sochor, J.S.; Baron, M.; Melcova, M.; Zidkova, J.; et al. A summary of new findings on the biological effects of selenium in selected animal species-A critical review. Int. J. Mol. Sci. 2017, 18, 2209. [CrossRef]

163. Fontagné-Dicharry, S.; Godin, S.; Liu, H.; Prabhu, P.A.J.; Bouyssiere, B.; Bueno, M.; Tacon, P.; Médale, F.; Kaushik, S.J. Influence of the forms and levels of dietary selenium on antioxidant status and oxidative stress-related parameters in rainbow trout (Oncorhynchus mykiss) fry. Brit. J. Nutr. 2015, 113, 1876-1887. [CrossRef] [PubMed]

164. Pacitti, D.; Lawan, M.M.; Sweetman, J.; Martin, S.A.M.; Feldmann, J.; Secombes, C.J. Selenium supplementation in fish: A combined chemical and biomolecular study to understand Sel-Plex assimilation and impact on selenoproteome expression in rainbow trout (Oncorhynchus mykiss). PLoS ONE 2015, 10, 0127041. [CrossRef]

165. Penglase, S.; Hamre, K.; Ellingsen, S. The selenium content of SEPP1 versus selenium requirements in vertebrates. Peer J. 2015, 1244. [CrossRef] [PubMed]

166. Wang, L.; Zhang, X.; Wu, L.; Liu, Q.; Zhang, D.; Yin, J. Expression of selenoprotein genes in muscle is crucial for the growth of rainbow trout (Oncorhynchus mykiss) fed diets supplemented with selenium yeast. Aquaculture 2018, 492, 82-90. [CrossRef]

167. Berntssen, M.H.G.; Sundal, T.K.; Olsvik, P.A.; Amlund, H.; Rasinger, J.D.; Sele, V.; Hamre, K.; Hillsted, M.; Buttle, L.; Ørnsrud, R. Sensitivity and toxic mode of action of dietary organic and inorganic selenium in Atlantic salmon (Salmo salar). Aquat. Toxicol. 2017, 192, 116-126. [CrossRef]

168. Du, L.C.; Yu, H.R.; Li, L.Y.; Zhang, Q.; Tian, Q.; Liu, J.Q.; Shan, L.L. Dietary selenium requirement of coho salmon (Oncorhynchus kisutch W.) alevins. Aquac. Int. 2021, 29, 2291-2304. [CrossRef]

169. Antony Jesu Prabhu, P.; Holen, E.; Espe, M.; Silva, M.S.; Holme, M.H.; Hamre, K.; Lock, E.; Waagbø, R. Dietary selenium required to achieve body homeostasis and attenuate pro-inflammatory responses in Atlantic salmon post-smolt exceeds the present EU legal limit. Aquaculture 2020, 526, 735413. [CrossRef]

170. Gatlin, D.M., III; Wilson, R.P. Dietary selenium requirement of fingerling channel catfish. J. Nutr. 1984, 114, 627-633. [CrossRef]

171. Wang, C.; Lovell, R.T. Organic selenium sources, selenomethionine and selenoyeast, have higher bioavailability than an inorganic selenium source, sodium selenite, in diets for channel catfish (Ictalurus puncatatus). Aquaculture 1997, 152, 223-234. [CrossRef]

172. Han, D.; Xie, S.; Liu, M.; Xiao, X.; Liu, H.; Zhu, X.; Yang, Y. The effects of dietary selenium on growth performances, oxidative stress and tissue selenium concentration of gibel carp (Carassius auratus gibelio). Aquac. Nutr. 2011, 17, 741-749. [CrossRef]

173. Zhu, L.; Han, D.; Zhu, X.; Yang, Y.; Jin, J.; Liu, H.; Xie, S. Dietary selenium requirement for on-growing gibel carp (Carassius auratus gibelio var. CAS III). Aquac. Res. 2016, 48, 2841-2851. [CrossRef]

174. Ning, L.; Yuwen, T.; Wang, W.; Wu, S.; Chen, F.; Zhang, H.; Pan, Q. Optimum selenium requirement of juvenile Nile tilapia, Oreochromis niloticus. Aquac. Nutr. 2020, 26, 528-535. [CrossRef]

175. Zhu, Y.; Chen, Y.; Liu, Y.; Yang, H.; Liang, G.; Tian, L. Effect of dietary selenium level on growth performance, body composition and hepatic glutathione peroxidase activities of largemouth bass Micropterus salmoide. Aquac. Res. 2011, 43, 1660-1668. [CrossRef]

176. Domínguez, D.; Sehnine, Z.; Castro, P.; Robaina, L.; Fontanillas, R.; Prabhu, P.A.J.; Izquierdo, M. Optimum selenium levels in diets high in plant-based feedstuffs for gilthead sea bream (Sparus aurata) fingerlings. Aquac. Nutr. 2019, 26, 579-589. [CrossRef]

177. Wang, L.; Xiao, J.X.; Hua, Y.; Xiang, X.W.; Zhou, Y.F.; Ye, L.; Shao, Q.J. Effects of dietary selenium polysaccharide on growth performance, oxidative stress and tissue selenium accumulation of juvenile black sea bream, Acanthopagrus schlegelii. Aquaculture 2019, 503, 389-395. [CrossRef]

178. Lin, Y.H.; Shiau, S.Y. Dietary selenium requirements of juvenile grouper, Epinephelus malabaricus. Aquaculture 2005, 250, 356-363. [CrossRef]

179. Lin, Y.H. Effects of dietary organic and inorganic selenium on the growth, selenium concentration and meat quality of juvenile grouper Epinephelus malabaricus. Aquaculture 2014, 430, 114-119. [CrossRef]

180. Liu, K.; Wang, X.J.; Ai, Q.; Mai, K.; Zhang, W. Dietary selenium requirement for juvenile cobia, Rachycentron canadum L. Aquac. Res. 2010, 41, 594-601. [CrossRef]

181. Bell, J.G.; Cowey, C.B.; Adron, J.W.; Shanks, A.M. Some effects of vitamin E and selenium deprivation on tissue enzyme levels and indices of tissue peroxidation in rainbow trout (Salmo gairdneri). Br. J. Nutr. 1985, 53, 149-157. [CrossRef]

182. Satoh, S.; Takeuchi, T.; Narabe, Y.; Watanabe, T. Effects of deletion of several trace elements from fish meal diets on growth and mineral composition of rainbow trout fingerlings. Nippon Suisan Gakkaishi 1983, 49, 1909-1916. [CrossRef] 
183. Wischhusen, P.; Paraillous, M.; Geraert, P.-A.; Briens, M.; Bueno, M.; Mounicou, S.; Bouyssiere, B.; Prabhu, A.J.; Kaushik, S.; Fauconneau, B.; et al. Effect of dietary Se in rainbow trout (Oncorhynchus mykiss) broodstock on antioxidant status, its parental transfer and oxidative status in the progeny. Aquaculture 2019, 507, 126-138. [CrossRef]

184. Hamilton, S.J. Review of selenium toxicity in the aquatic food chain. Sci. Total Environ. 2004, 326, 1-31. [CrossRef]

185. Pedersen, T.V.; Block, M.; Part, P. Effect of selenium on the uptake of methyl mercury across perfused gills of rainbow trout Oncorhynchus mykiss. Aquat. Toxicol. 1998, 40, 361-373. [CrossRef]

186. Hamilton, S.J.; Buhl, K.J. Acute toxicity of boron molybdenum and selenium to fry of Chinook salmon and coho salmon. Arch. Environ. Contam. Toxicol. 1990, 19, 366-373. [CrossRef]

187. Berntssen, M.H.G.; Betancor, M.; Caballero, M.J.; Hillestad, M.; Rasinger, J.; Hamre, K.; Sele, V.; Amlund, H.; Ørnsrud, R. Safe limits of selenomethionine and selenite supplementation to plant-based Atlantic salmon feeds. Aquaculture 2018, 495, 617-630. [CrossRef]

188. Tashjian, D.H.; Teh, S.J.; Sogomonyan, A.; Hung, S.S.O. Bioaccumulation and chronic toxicity of dietary l-selenomethionine in juvenile white sturgeon (Acipenser transmontanus). Aquat. Toxicol. 2006, 79, 401-409. [CrossRef]

189. De Riu, N.; Lee, J.W.; Huang, S.S.Y.; Moniello, G.; Hung, S.S.O. Effect of dietary selenomethionine on growth performance, tissue burden, and histopathology in green and white sturgeon. Aquat. Toxicol. 2014, 148, 65-73. [CrossRef]

190. Zee, J.; Patterson, S.; Wiseman, S.; Hecker, M. Is hepatic oxidative stress a main driver of dietary selenium toxicity in white sturgeon (Acipenser transmontanus). Ecotox. Environ. Saf. 2016, 133, 334-340. [CrossRef]

191. Schultz, R.; Hermanutz, R. Transfer of toxic concentrations of selenium from parent to progeny in the fathead minnow (Pimephales promelas). Bull. Environ. Contam. Toxicol. 1990, 45, 568-573. [CrossRef]

192. Hicks, B.D.; Hilton, J.W.; Ferguson, H.W. Influence of dietary selenium on the occurrence of nephrocalcinosis in the rainbow trout, Salmo gairdneri Richardson. J. Fish. Dis. 1984, 7, 379-389. [CrossRef]

193. Kupsco, A.; Schlenk, D. Molecular mechanisms of selenium-Induced spinal deformities in fish. Aquat. Toxicol. 2016, 179, 143-150. [CrossRef] [PubMed]

194. EFSA. Scientific opinion on the safety and efficacy of selenium compounds (E8) as feed additives for all animal species: Sodium selenite, based on a dossier submitted by Retorte GmbH Selenium Chemicals and Metals. EFSA J. 2016, 14, 4398. [CrossRef]

195. Maier, K.J.; Knight, A.W. Ecotoxicology of selenium in freshwater systems. Rev. Environ. Contam. Toxicol. 1994, $134,31-48$.

196. Knight, R.; Marlatt, V.L.; Baker, J.A.; Lo, B.P.; Debruyn, A.M.H.; Elphick, J.R.; Martyniuk, C.J. Dietary selenium disrupts hepatic triglyceride stores and transcriptional networks associated with growth and Notch signaling in juvenile rainbow trout. Aquat. Toxicol. 2016, 180, 103-114. [CrossRef]

197. Pacitti, D.; Lawan, M.M.; Feldmann, J.; Sweetman, J.; Wang, T.; Martin, S.A.M.; Secombes, C.J. Impact of selenium supplementation on fish antiviral responses: A whole transcriptomic analysis in rainbow trout (Oncorhynchus mykiss) fed supra nutritional levels of Sel-Plex ${ }^{\circledR}$. BMC Genom. 2016, 17, 1-26. [CrossRef]

198. Rayman, M.P. The use of high-selenium yeast to raise selenium status: How does it measure up? Br. J. Nutr. 2004, 92, 557-573. [CrossRef]

199. Schrauzer, G.N. Selenium yeast: Composition, quality, analysis, and safety. Pure Appl. Chem. 2006, 78, 105-109. [CrossRef]

200. Scott, M.L.; Thompson, J.N. Selenium content of feedstuffs and effects of dietary selenium levels upon tissue selenium in chick and poults. Poult. Sci. 1971, 50, 1742-1748. [CrossRef]

201. Canton, S.P.; Van Derveer, W.D. Selenium toxicity to aquatic life: An argument for sediment-based water quality criteria. Environ. Toxicol. Chem. 1997, 16, 1255-1259. [CrossRef]

202. Henry, P.R.; Ammerman, C.B. Selenium bioavailability. In Bioavailability of Nutrients for Animal: Amino Acids, Minerals, and Vitamins; Elsevier/Academic Press: Cambridge, MA, USA, 1995; pp. 303-336.

203. Fairweather-Tait, S.J.; Collings, R.; Hurst, R. Selenium bioavailability: Current knowledge and future research requirements. Am. J. Clin. Nutr. 2010, 91, 1484-1491. [CrossRef] [PubMed]

204. Thiry, C.; Ruttens, A.; De Temmerman, L.; Schneider, Y.J.; Pussemier, L. Current knowledge in species-related bioavailability of selenium in food. Food Chem. 2012, 130, 767-784. [CrossRef]

205. Rider, S.A.; Davies, S.J.; Jha, A.N.; Clough, R.; Sweetman, J.W. Bioavailability of co-supplemented organic and inorganic zinc and selenium sources in a white fishmeal-based rainbow trout (Oncorhynchus mykiss) diet. J. Anim. Physiol. Anim. Nutr. 2010, 94, 99-110. [CrossRef]

206. Sele, V.; Ørnsrud, R.; Sloth, J.J.; Berntssen, M.H.G.; Amlund, H. Selenium and selenium species in feeds and muscle tissue of Atlantic salmon. J. Trace Elem. Med. Biol. 2018, 47, 124-133. [CrossRef]

207. Le, K.T.; Fotedar, R. Bioavailability of selenium from different dietary sources in yellowtail kingfish (Seriola lalandi). Aquaculture 2014, 420, 457-462. [CrossRef]

208. Mechlaoui, M.; Dominguez, D.; Robaina, L.; Geraert, P.A.; Kaushik, S.; Saleh, R.; Briens, M.; Montero, D.; Izquierdo, M. Effects of different dietary selenium sources on growth performance, liver and muscle composition, antioxidant status, stress response and expression of related genes in gilthead seabream (Sparus aurata). Aquaculture 2019, 507, 251-259. [CrossRef]

209. Godin, S.; Fontagné-Dicharry, S.; Bueno, M.; Tacon, P.; Prabhu, P.A.J.; Kaushik, S.; Médale, F.; Bouyssiere, B. Influence of dietary selenium species on selenoamino acid levels in rainbow trout. J. Agric. Food Chem. 2015, 63, 6484-6492. [CrossRef]

210. Bell, J.G.; Cowey, C.B. Digestibility and bioavailability of dietary selenium from fishmeal, selenite, selenomethionine and selenocystine in Atlantic salmon (Salmo salar). Aquaculture 1989, 81, 61-68. [CrossRef] 
211. Gabrielsen, B.J.; Opstvedt, J. Availability of selenium in fish meal in comparison with soybean meal, corn gluten meal and selenomethionine relative to selenium in sodium selenite for restoring glutathione peroxidase activity in selenium-depleted chicks. J. Nutr. 1980, 110, 1096-1100. [CrossRef]

212. Sissener, N.H.; Julshamn, K.; Espe, M.; Lunestad, B.T.; Hemre, G.I.; Waagbø, R.; Måge, A. Surveillance of selected nutrients, additives and undesirables in commercial Norwegian fish feeds in the years 2000-2010. Aquac. Nutr. 2013, 19, 555-572. [CrossRef]

213. Betancor, M.; Dam, T.; Walton, J.; Morken, T.; Campbell, P.; Tocher, D. Modulation of selenium tissue distribution and selenoprotein expression in Atlantic salmon (Salmo salar L.) fed diets with graded levels of plant ingredients. Br. J. Nutr. 2016, 115, 1325-1338. [CrossRef] [PubMed]

214. Silva, M.S.; Kröckel, S.; Jesu Prabhu, P.A.; Koppe, W.; Ørnsrud, R.; Waagbø, R.; Araujo, P.; Amlund, H. Apparent availability of zinc, selenium and manganese as inorganic metal salts or organic forms in plant-based diets for Atlantic salmon (Salmo salar). Aquaculture 2019, 503, 562-570. [CrossRef]

215. Vallee, B.L.; Falchuk, K.H. The biochemical basis of zinc physiology. Physiol. Rev. 1993, 73, 79-118. [CrossRef]

216. McCall, K.A.; Huang, C.-C.; Fierke, C.A. Function and mechanism of zinc metalloenzymes. J. Nutr. 2000, 130, 1437S-1446S. [CrossRef] [PubMed]

217. Passerini, A.; Andreini, C.; Menchetti, S.; Rosato, A.; Frasconi, P. Predicting zinc binding at the proteome level. BMC Bioinf 2007, 5, 8-39. [CrossRef] [PubMed]

218. Maret, W. Zinc biochemistry: From a single zinc enzyme to key element of life. Adv. Nutr. 2013, 4, 82-91. [CrossRef]

219. Kambe, T.; Tsuji, T.; Hashimoto, A.; Itsumura, N. The physiological, biochemical, and molecular roles of zinc transporters in zinc homeostasis and metabolism. Physiol. Rev. 2015, 95, 749-784. [CrossRef]

220. Fukada, T.; Kambe, T. Molecular and genetic features of zinc transporters in physiology and pathogenesis. Metallomics 2011, 3 , 662-674. [CrossRef]

221. Feeney, G.P.; Zheng, D.; Kille, P.; Hogstrand, C. The phylogeny of teleost ZIP and ZnT zinc transporters and their tissue specific expression and response to zinc in zebrafish. Biochim. Biophy. Acta (BBA) Gene Struct. Express 2005, 1732, 88-95. [CrossRef]

222. Zhao, L.; Xia, Z.; Wang, F. Zebrafish in the sea of mineral (iron, zinc, and copper) metabolism. Front. Pharmacol. 2014, 5-33. [CrossRef]

223. Spry, D.I.; Hodson, P.V.; Wood, C.M. Relative contributions of dietary and waterborne zinc in rainbow trout, Salmo gairdneri. Can. J. Fish. Aquat. Sci. 1988, 45, 32-41. [CrossRef]

224. Pentreath, R.J. The accumulation and retention of ${ }^{65} \mathrm{Zn}$ and ${ }^{54} \mathrm{Mn}$ by the plaice, Pleuronectes platessa L. J. Exp. Mar. Biol. Ecol. 1973, 12, 1-18. [CrossRef]

225. Lall, S.P.; Bishop, F.J. Studies on mineral and protein utilization by Atlantic salmon (Salmo salar) grown in sea water. Fish. Mar. Serv. Tech. Rep. 1977, 688, 1-16.

226. Hogstrand, C.; Verbost, P.M.; Bonga, S.E.; Wood, C.M. Mechanisms of zinc uptake in gills of freshwater rainbow trout: Interplay with calcium transport. Am. J. Physiol. 1996, 270, 1141-1147. [CrossRef] [PubMed]

227. Hardy, R.W.; Sullivan, C.V.; Koziol, A.M. Absorption, body distribution, and excretion of dietary zinc by rainbow trout (Salmo gairdneri). Fish Physiol. Biochem. 1987, 3, 133-143. [CrossRef] [PubMed]

228. Niyogi, S.; Wood, C.M. Interaction between dietary calcium supplementation and chronic waterborne zinc exposure in juvenile rainbow trout, Oncorhynchus mykiss. Comp. Biochem. Physiol. Part C 2006, 143, 91-102. [CrossRef]

229. Antony Jesu Prabhu, P.; Stewart, T.; Silva, M.; Amlund, H.; Ørnsrud, R.; Lock, E.J.; Waagbo, R.; Hogstrand, C. Zinc uptake in fish intestinal epithelial model RTgutGC: Impact of media ion composition and methionine chelation. J. Trace Elem. Med. Biol. 2018, 50, 377-383. [CrossRef] [PubMed]

230. Maage, A.; Julshamn, K. Assessment of zinc status in juvenile Atlantic salmon (Salmo salar) by measurement of whole body and tissue levels of zinc. Aquaculture 1993, 117, 179-191. [CrossRef]

231. Ogino, C.; Yang, G.-Y. Requirement of rainbow trout for dietary zinc. Bull. Jpn. Soc. Sci. Fish. 1978, 44, 1015-1018. [CrossRef]

232. Welker, T.; Barrows, F.; Overturf, K.; Gaylord, G.; Sealey, W. Optimizing zinc supplementation levels of rainbow trout (Oncorhynchus mykiss) fed practical type fishmeal- and plant-based diets. Aquac. Nutr. 2016, 22, 91-108. [CrossRef]

233. Gatlin, D.M., III; Wilson, R.P. Dietary zinc requirement of fingerling channel catfish. J. Nutr. 1983, 113, 630-635. [CrossRef] [PubMed]

234. Luo, Z.; Tan, X.Y.; Zheng, J.L.; Chen, Q.L.; Liu, C.X. Quantitative dietary zinc requirement of juvenile yellow catfish Pelteobagrus fulvidraco, and effects on hepatic intermediary metabolism and antioxidant responses. Aquaculture 2011, 319, 150-155. [CrossRef]

235. Ogino, C.; Yang, G.Y. Requirement of carp for dietary zinc. Bull. Jpn. Soc. Sci. Fish. 1979, 45, 967-969. [CrossRef]

236. Tan, L.N.; Feng, L.; Liu, Y.; Jiang, J.; Jiang, W.D.; Hu, K.; Zhou, X.Q. Growth, body composition and intestinal enzyme activities of juvenile Jian carp (Cyprinus carpio var. Jian) fed graded levels of dietary zinc. Aquac. Nutr. 2011, 17, 338-345. [CrossRef]

237. Liang, J.J.; Yang, H.J.; Liu, Y.J.; Tian, L.X.; Liang, G.Y. Dietary zinc requirement of juvenile grass carp (Ctenopharyngodon idella) based on growth and mineralization. Aquac. Nutr. 2012, 18, 380-387. [CrossRef]

238. Musharraf, M.; Khan, M.A. Dietary zinc requirement of fingerling Indian major carp, Labeo rohita (Hamilton). Aquaculture 2019, 503, 489-498. [CrossRef]

239. Lin, Y.H.; Jiang, L.C.; Shiau, S.-Y. Dietary zinc requirements of juvenile tilapia, Oreochromis niloticus x O. aureus. J. Fish. Soc. Taiwan 2008, 35, 117-125. 
240. Li, M.R.; Huang, C.H. Effect of dietary zinc level on growth, enzyme activity and body trace elements of hybrid tilapia, Oreochromis niloticus $\times$ O. aureus, fed soya bean meal-based diets. Aquac. Nutr. 2015, 22, 1320-1327. [CrossRef]

241. McLain, W.; Gatlin, D.M., III. Dietary zinc requirement of Oreochromis aureus and effects of dietary calcium and phytate on zinc bioavailability. J. World Aquac. Soc. 1988, 19, 103-108. [CrossRef]

242. Eid, A.E.; Ghonim, S.I. Dietary zinc requirement of fingerling Oreochromis niloticus. Aquaculture 1994, 119, 259-264. [CrossRef]

243. Huang, F.; Jiang, M.; Wen, H.; Wu, F.; Liu, W.; Tian, J.; Yang, C. Dietary zinc requirement of adult Nile tilapia (Oreochromis niloticus) fed semi-purified diets, and effects on tissue mineral composition and antioxidant responses. Aquaculture 2015, 439, 53-59. [CrossRef]

244. Moazenzadeh, K.; Islami, H.R.; Zamini, A.; Soltani, M. Dietary zinc requirement of Siberian sturgeon (Acipenser baerii, Brandt 1869) juveniles, based on the growth performance and blood parameters. Int. Aquat. Res. 2017, 9, 25-35. [CrossRef]

245. Gatlin, D.M., III; O'Connell, J.P.; Scarpa, J. Dietary zinc requirement of the red drum, Sciaenops ocellatus. Aquaculture 1991, 92, 259-265. [CrossRef]

246. Jiang, M.; Wu, F.; Huang, F.; Wen, H.; Liu, W.; Tian, J.; Changgeng, Y.; Wang, W. Effects of dietary Zn on growth performance, antioxidant responses, and sperm motility of adult blunt snout bream, Megalobrama amblycephala. Aquaculture 2016, 464, 121-128. [CrossRef]

247. Houng-Yung, C.; Yu-Chun, C.; Li-Chi, H.; Meng-Hsien, C. Dietary zinc requirements of juvenile grouper, Epinephelus malabaricus. Aquaculture 2014, 432, 360-364. [CrossRef]

248. Xu, Z.; Dong, X.; Liu, C. Dietary zinc requirement of juvenile cobia (Rachycentron canadum). Fish. Sci. 2007, 26, 138-141.

249. Ketola, H.G. Influence of dietary zinc on cataracts in rainbow trout (Salmo gairdneri). J. Nutr. 1979, 105, 965-969. [CrossRef] [PubMed]

250. Richardson, N.L.; Higgs, D.A.; Beames, R.M.; McBride, J.R. Influence of dietary calcium, phosphorus, zinc and sodium phytate level on cataract incidence, growth and histopathology in juvenile chinook salmon (Oncorhynchus tshawytscha). J. Nutr. 1985, 115, 553-567. [CrossRef] [PubMed]

251. Waagbø, R.; Tröße, C.; Fontanillas, R.; Breck, O. Dietary histidine supplementation prevents cataract development in adult Atlantic salmon, Salmo salar L., in seawater. Br. J. Nutr. 2010, 104, 1460-1470. [CrossRef]

252. Bjerkås, E.; Breck, O.; Waagbø, R. The role of nutrition in cataract formation in farmed fish. CAB Rev. Perspect. Agric. Vet. Scie. Nutr. Nat. Resour. 2006, 33, 1-16. [CrossRef]

253. Bjerkås, E.; Sveier, H. The influence of nutritional and environmental factors on osmoregulation and cataracts in Atlantic salmon (Salmo salar L). Aquaculture 2004, 235, 101-122. [CrossRef]

254. Wekell, J.C.; Shearer, K.D.; Gauglitz, E.J., Jr. Zinc supplementation of trout diets: Tissue indicators of body zinc status. Prog. Fish.-Cult. 1986, 48, 205-212.

255. Wekell, J.C.; Shearer, K.D.; Houle, C.R. High zinc supplementation of rainbow trout diets. Prog. Fish.-Cult. 1983, 45, 144-147. [CrossRef]

256. Jeng, S.S.; Sun, L.T. Effects of dietary zinc levels on zinc concentrations in tissues of common carp. J. Nutr. 1981, 111, 134-140. [CrossRef]

257. Alsop, D.H.; Wood, C.M. Influence of waterborne cations on zinc uptake and toxicity in rainbow trout, Oncorhynchus mykiss. Can. J. Fish. Aquat. Sci. 1999, 56, 2112-2119. [CrossRef]

258. Bielmyer, G.K.; Bullington, J.B.; DeCarlo, C.A.; Chalk, S.J.; Smith, K. The effects of salinity on acute toxicity of zinc to two euryhaline species of fish, Fundulus heteroclitus and Kryptolebias marmoratus. Integ. Comp. Biol. 2012, 52, 753-760. [CrossRef] [PubMed]

259. Loro, V.L.; Nogueira, L.; Nadella, S.R.; Wood, C.M. Zinc bioaccumulation and ionoregulatory impacts in Fundulus heteroclitus exposed to sublethal waterborne zinc at different salinities. Comp. Biochem. Physiol. Toxic. Pharm. 2014, 166 C, 96-104. [CrossRef]

260. Satoh, S.; Tabata, K.; Izume, K.; Takeuchi, T.; Watanabe, T. Effect of dietary tricalcium phosphate on availability of zinc to rainbow trout. Nippon Suisan Gakkaishi 1987, 53, 1199-1205.

261. Satoh, S.; Poe, W.E.; Wilson, R.P. Effect of supplemental phytate and/or tricalcium phosphate on weight gain, feed efficiency and zinc content in vertebrae of channel catfish. Aquaculture 1989, 80, 155-161. [CrossRef]

262. Apines-Amar, M.J.S.; Satoh, S.; Caipang, C.M.A.; Kiron, V.; Watanabe, T.; Aoki, T. Amino acid-chelate: A better source of Zn, Mn and $\mathrm{Cu}$ for rainbow trout, Oncorhynchus mykiss. Aquaculture 2004, 240, 345-358. [CrossRef]

263. EFSA. Scientific opinion on the safety and efficacy of zinc compounds (E6) as feed additives for all animal species (zinc acetate, dihydrate; zinc chloride, anhydrous; zinc oxide; zinc sulphate, heptahydrate; zinc sulphate, monohydrate; zinc chelate of amino acids, hydrate; zinc chelate of glycine, hydrate), based on a dossier submitted by FEFANA asbl. EFSA J. 2015, 13, 46. [CrossRef]

264. Apines, M.J.S.; Satoh, S.; Kiron, V.; Watanabe, T.; Aoki, T. Availability of supplemental amino acid-chelated trace elements in diets containing tricalcium phosphate and phytate to rainbow trout, Oncorhynchus mykiss. Aquaculture 2003, 225, 431-444. [CrossRef]

265. Apines, M.J.S.; Satoh, S.; Kiron, V.; Watanabe, T.; Fujita, S. Bioavailability and tissue distribution of amino acid chelated trace elements in rainbow trout Oncorhynchus mykiss. Fish. Sci. 2003, 69, 722-730. [CrossRef]

266. Rider, S.A.; Davies, S.J.; Jha, A.N.; Fisher, A.A.; Knight, J.; Sweetman, J.W. Supra-nutritional dietary intake of selenite and selenium yeast in normal and stressed rainbow trout (Oncorhynchus mykiss): Implications on selenium status and health responses. Aquaculture 2009, 295, 282-291. [CrossRef] 
267. Li, M.H.; Robinson, E.H. Comparison of chelated zinc and zinc sulfate as zinc sources for growth and bone mineralization of channel catfish (Ictalurus punctatus) fed practical diets. Aquaculture 1996, 146, 237-243. [CrossRef]

268. Domínguez, D.; Robaina, L.; Zamorano, M.J.; Karalazos, V.; Izquierdo, M. Effects of zinc and manganese sources on gilthead seabream (Sparus aurata) fingerlings. Aquaculture 2019, 505, 386-392. [CrossRef]

269. Hardy, R.W.; Shearer, K. Effect of dietary calcium phosphate and zinc supplementation on whole body zinc concentration of rainbow trout (Salmo gairdneri). Can. J. Fish. Aquat. Sci. 1985, 42, 181-184. [CrossRef]

270. Lönnerdal, B. Dietary factors influencing zinc absorption. J. Nutr. 2000, 130, 1378-1383. [CrossRef]

271. Kumar, V.; Sinha, A.K.; Makkar, H.P.S.; De Boeck, G.; Becker, K. Phytate and phytase in fish nutrition. J. Anim. Physiol. Anim. Nutr. 2012, 96, 335-364. [CrossRef]

272. Hetzel, B.S.; Welby, M.C. Iodine. In Handbook of Nutritionally Essential Mineral Elements; O'Dell, B.L., Sunde, R.A., Eds.; Marcel Dekker Inc.: New York, NY, USA, 1997; pp. 557-582.

273. Higgs, D.A.; Fagerlund, U.H.M.; Eales, J.G.; McBride, J.R. Application of thyroid and steroid hormones as anabolic agents in fish culture. Comp. Biochem. Physiol. Part B Comp. Biochem. 1982, 73, 143-176. [CrossRef]

274. Cyr, D.G.; Eales, J.G. Interrelationships between thyroidal and reproductive systems in Fish. Rev. Fish. Biol. Fish. 1996, 6, 165-200. [CrossRef]

275. Cyr, D.G.; Bromage, N.R.; Dustin, J.; Eales, J.G. Seasonal patterns in serum levels of thyroid hormones and sex steroids in relation to photoperiod-induced changes in spawning time in rainbow trout, Salmo gairdneri. Gen. Comp. Endoc. 1988, 69, 217-225. [CrossRef]

276. Lebel, J.M.; Leloup, J. La triiodothyronine est necessaire á l'acclimation á l'eau de mer de la truite fario (Salmo trutta) ou arc en ciel (Oncorhynchus mykiss). Comput. Rendus Acad. Sci. Paris 1992, 314, 461-468.

277. Blanton, M.L.; Specker, J.L. The hypothalamic-pituitary-thyroid (HPT) axis in fish and its role in fish development and reproduction. Crit. Rev. Toxicol. 2007, 37, 97-115. [CrossRef]

278. Power, D.M.; Einarsdottir, I.E.; Pittman, K.; Sweeney, G.E.; Hildahl, J.; Campinho, M.A.; Silva, N.; Saele, Ø.; Burgos, M.G.; Smaradottir, H.; et al. The molecular and endocrine basis of flatfish metamorphosis. Rev. Fish. Sci. 2008, 16, 95-111. [CrossRef]

279. Eales, J.G. The relationship between ingested thyroid hormones, thyroid homeostasis and iodine metabolism in humans and teleost fish. Gen. Comp. Endoc. 2019, 280, 62-72. [CrossRef] [PubMed]

280. Moren, M.; Sloth, J.J.; Hamre, K. Uptake of iodide from water in Atlantic halibut larvae (Hippoglossus hippoglossus L). Aquaculture 2008, 285, 174-178. [CrossRef]

281. Geven, E.J.W.; Nguyen, N.-K.; Boogaart, M.; Spanings, F.A.T.; Flik, G.; Klaren, P.H.M. Comparative thyroidology: Thyroid gland location and iodothyronine dynamics in Mozambique tilapia (Oreochromis mossambicus Peters) and common carp (Cyprinus carpio L.). J. Exp. Biol. 2007, 210, 4005-4015. [CrossRef]

282. Hunt, D.W.C.; Eales, J.G. Iodine balance in rainbow trout (Salmo gairdneri) and effects of testosterone propionate. J. Fish. Res. Board Can. 1979, 36, 282-285. [CrossRef]

283. Speacker, J.L.; Eales, J.G.; Tagawa, M.; Tyler, W.A., III. Parr-smolt transformation in Atlantic salmon: Thyroid hormone deiodination in liver and brain and endocrine correlates of change in rheotactic behavior. Can. J. Zool. 2000, 78, 696-705. [CrossRef]

284. Habibi, H.R.; Nelson, E.R.; Allan, E.R.O. New insights into thyroid hormone function and modulation of reproduction in goldfish. Gen. Comp. Endoc 2012, 175, 19-26. [CrossRef]

285. Brown, C.L.; Urbinati, E.C.; Zhang, W.; Brown, S.B.; McComb-Kobza, M. Maternal thyroid and glucocorticoid hormone interactions in larval fish development, and their applications in aquaculture. Rev. Fish. Sci. Aquac. 2014, 22, 207-220. [CrossRef]

286. Einarsdottir, I.E.; Silva, N.; Power, D.M.; Smaradottir, H.; Bjornsson, B.T. Thyroid and pituitary gland development from hatching through metamorphosis of a teleost flatfish, the Atlantic halibut. Anat. Embryol. 2006, 211, 247-260. [CrossRef]

287. Ribeiro, A.R.A.; Ribeiro, L.; Saele, O.; Dinis, M.T.; Moren, M. Iodine and selenium supplementation increased survival and changed thyroid hormone status in Senegalese sole (Solea senegalensis) larvae reared in a recirculation system. Fish Physiol. Biochem. 2012, 38, 725-734. [CrossRef]

288. Penglase, S.; Harboe, T.; Sæle, Ø.; Helland, S.; Nordgreen, A.; Hamre, K. Iodine nutrition and toxicity in Atlantic cod (Gadus morhua) larvae. Peer J. 2013, 1, 20. [CrossRef] [PubMed]

289. Hamre, K.; Yúfera, M.; Rønnestad, I.; Boglione, C.; Conceição, L.E.C.; Izquierdo, M. Fish larval nutrition and feed formulation: Knowledge gaps and bottlenecks for advances in larval rearing. Rev. Aquac. 2013, 5, 26-58. [CrossRef]

290. Sherrill, J.; Whitaker, B.R.; Wong, G.T.F. Effects of ozonation on the speciation of dissolved iodine in artificial seawater. J. Zoo Wild. Med. 2004, 35, 347-355. [CrossRef] [PubMed]

291. Tonacchera, M.; Pinchera, A.; Dimida, A.; Ferrarini, E.; Agretti, P.; Vitti, P.; Santini, F.; Crump, K.; Gibbs, J. Relative potencies and additivity of perchlorate, thiocyanate, nitrate, and iodide on the inhibition of radioactive iodide uptake by the human sodium iodide symporter. Thyroid 2004, 14, 1012-1019. [CrossRef]

292. Morris, A.L.; Hamlin, H.J.; Francis-Floyd, R.; Sheppard, B.J.; Guillette, L.J. Nitrate-induced goiter in captive white spotted bamboo sharks Chiloscyllium plagiosum. J. Aquat. Anim. Health 2011, 23, 92-99. [CrossRef]

293. Marine, D. Further observations and experiments on goiter in brook trout. J. Exp. Med. 1914, 19, 70-75. [CrossRef]

294. Delange, F. The disorders induced by iodine deficiency. J. Thyroid 1994, 4, 107-128. [CrossRef]

295. Vanderpas, J. Nutritional epidemiology and thyroid hormone metabolism. Ann. Rev. Nutr. 2006, 26, 293-322. [CrossRef] 
296. Woodall, A.N.; LaRoche, G. Nutrition of salmonid fishes. 11. Iodide requirements of chinook salmon. J. Nutr. 1964, 82, 475-482. [CrossRef] [PubMed]

297. Lall, S.P.; Paterson, W.D.; Hines, J.A.; Adams, N.J. Control of bacterial kidney disease in Atlantic salmon Salmo salar L. by dietary modification. J. Fish. Dis. 1985, 8, 113-124. [CrossRef]

298. Julshamn, K.; Dahl, L.; Eckhoff, K. Determination of iodine in seafood by inductively coupled plasma/mass spectrometry. J. Assoc. Off. Anal. Chem. 2001, 84, 1976-1983. [CrossRef]

299. Lall, S.P. Macro and trace elements in fish and shellfish. In Fish and Fishery Products: Composition, Nutritive Properties and Stability; Ruiter, A., Ed.; CAB International: Wallingford, UK, 1995; pp. 187-213.

300. Teas, J.; Pino, S.; Critchley, A.; Braverman, L.E. Variability of iodine content in common commercially available edible seaweeds. Thyroid 2004, 14, 836-841. [CrossRef]

301. Bell, J.M. Nutrients and toxicants in rapeseed meal: A review. J. Anim. Sci. 1984, 58, 996-1010. [CrossRef] [PubMed]

302. Mawson, R.; Heaney, R.K.; Zdunczyk, Z.; Kozlowska, H. Rapeseed meal—Glucosinolates and their antinutritional effects. Part 4. Goitrogenicity and internal organs abnormalities in animals. Nahrung 1994, 38, 178-191. [CrossRef]

303. Leatherland, J.F.; Hilton, J.W.; Slinger, S.J. Effects of thyroid hormone supplementation of canola meal-based diets on growth, and interrenal and thyroid gland physiology of rainbow trout (Salmo gairdneri). Fish Physiol. Biochem. 1987, 3, 73-82. [CrossRef] [PubMed]

304. Burel, C.; Boujard, T.; Kaushik, S.; Boeuf, G.; Mol, K.; van der Geyten, S.; Darras, V.; Kühn, E.; Pradet-Balade, B.; Quérat, B. Effects of rapeseed meal-glucosinolates on thyroid metabolism and feed utilization in rainbow trout. Gen. Comp. Endocrinol. 2001, 124, 343-358. [CrossRef]

305. Francis, G.; Makkar, H.P.S.; Becker, K. Antinutritional factors present in plant-derived alternate feed ingredients and their effects in fish. Aquaculture 2001, 199, 197-227. [CrossRef]

306. Vincent, J.B. The biochemistry of chromium. J. Nutr. 2000, 130, 715-718. [CrossRef] [PubMed]

307. Vincent, J.B. New evidence against chromium as an essential trace element. J. Nutr. 2017, 147, 2212-2219. [CrossRef] [PubMed]

308. EFSA. Scientific opinion on dietary reference values for chromium. EFSA J. 2014, 12, 1-27. [CrossRef]

309. Hertz, Y.; Madar, Z.; Hepher, B.; Gertler, A. Glucose metabolism in the common carp (Cyprinus carpio L.): The effects of cobalt and chromium. Aquaculture 1989, 76, 255-267. [CrossRef]

310. Shiau, S.Y.; Lin, S.F. Effects of supplementation of dietary chromium and vanadium on the utilisation of different carbohydrates in tilapia, (Oreochromis niloticus x O. aureus). Aquaculture 1993, 110, 321-330. [CrossRef]

311. Ng, W.K.; Wilson, R.P. Chromic oxide inclusion in the diet does not affect glucose utilization or chromium retention by channel catfish, Ictalurus punctatus. J. Nutr. 1997, 127, 2357-2362. [CrossRef]

312. Fernandez, F.; Miquel, A.G.; Martinez, R.; Serra, E.; Guinea, J.; Narbaiza, F.J.; Caseras, A.; Baanante, I.V. Dietary chromium oxide does not affect the utilization of organic compounds but can alter the utilization of mineral salts in gilthead sea bream Sparus aurata. J. Nutr. 1999, 129, 1053-1059. [CrossRef]

313. Liu, T.; Wen, H.; Jiang, M.; Yuan, D.; Gao, P.; Zhao, Y.; Wu, F.; Liu, W. Effect of dietary chromium picolinate on growth performance and blood parameters in grass carp fingerling, Ctenopharyngodon idellus. Fish Physiol. Biochem. 2010, 36, 565-572. [CrossRef]

314. Giri, A.F.; Sahu, N.P.; Saharan, N.; Dash, G. Effect of dietary supplementation of chromium on growth and biochemical parameters of Labeo rohita (Hamilton) fingerlings. Ind. J. Fish. 2014, 61, 73-81.

315. Wang, J.; Ai, Q.; Mai, K.; Xu, H.; Zuo, R. Dietary chromium polynicotinate enhanced growth performance, feed utilization, and resistance to Cryptocaryon irritans in juvenile large yellow croaker (Larmichthys crocea). Aquaculture 2014, 432, 321-326. [CrossRef]

316. Shiau, S.Y.; Shy, S.M. Dietary chromic oxide inclusion level required to maximize glucose utilization in hybrid tilapia (Oreochromis niloticus x O. aureus). Aquaculture 1998, 161, 357-364. [CrossRef]

317. Tacon, A.G.J.; Beveridge, M.M. Effects of dietary trivalent chromium on rainbow trout. Nutr. Rep. Int. 1982, 25, 49-56.

318. Jain, K.K.; Sinha, A.; Srivastava, P.P.; Berendra, D.K. Chromium: An efficient growth enhancer in Indian major carp, Labeo rohita. J. Aquac. Trop. 1994, 9, 49-54.

319. Calamari, D.; Solbé, J.F. Report on chromium and freshwater fish. In Water Quality for Freshwater Fish; Howells, G., Ed.; Gordon and Breach Science Publisher: Yverdon, Switzerland, 1994; pp. 1-30.

320. Gatta, P.P.; Thomson, K.D.; Smullen, R.; Piva, A.; Testi, S.; Adams, A. Dietary organic chromium supplementation and its effect on the immune response of rainbow trout (Oncorhynchus mykiss). Fish. Shellfish Immun. 2001, 11, 371-382. [CrossRef]

321. Reid, S.D. Molybdenum and chromium. Fish Physiol. 2012, 31A, 376-415.

322. Bakshi, A.; Panigrahi, A.K. A comprehensive review on chromium induced alterations in fresh water fishes. Tox. Rep. 2018, 5, 440-447. [CrossRef]

323. Lovell, R.T.; Limsuwan, T. Intestinal synthesis and dietary non-essentiality of vitamin $\mathrm{B}_{12}$ for Tilapia niloticus. Trans. Am. Fish. Soc. 1982, 111, 485-490. [CrossRef]

324. Shiau, S.Y.; Lung, C.Q. No dietary vitamin $\mathrm{B}_{12}$ required for juvenile tilapia Oreochromis niloticus $\times$ O. aureus. Comp. Biochem. Physiol. 1993, 105A, 147-150.

325. Limsuwan, T.; Lovell, R.T. Intestinal synthesis and absorption of vitamin $B_{12}$ in channel catfish. J. Nutr. 1981, 111, $2125-2132$. [CrossRef] [PubMed]

326. Anadu, D.I.; Anozie, O.C.; Anthony, A.D. Growth responses of Tilapia zillii fed diets containing various levels of ascorbic acid and cobalt chloride. Aquaculture 1990, 88, 329-336. [CrossRef] 
327. Lin, Y.H.; Wu, J.Y.; Shiau, S.Y. Dietary cobalt can promote gastrointestinal bacterial production of vitamin $B_{12}$ in sufficient amounts to supply growth requirements of grouper, Epinephelus malabaricus. Aquaculture 2010, 302, 89-93.

328. Baudin, J.P.; Veran, M.P.; Adam, C.; Garnier-LaPlace, J. Dietary uptake, retention and tissue distribution of ${ }^{54} \mathrm{Mn},{ }^{60} \mathrm{Co}$ and ${ }^{137} \mathrm{Cs}$ in rainbow trout, Oncorhynchus mykiss Walbaum. Water Res. 2000, 34, 2869-2878.

329. Blust, R. Cobalt. In Fish Physiology: Homeostasis and Toxicology of Essential Metals; Wood, C.M., Farrell, A.M., Brauner, C.J., Eds.; Elsevier/Academic Press: Cambridge, MA, USA, 2012; pp. 291-326.

330. Kuenze, J.; Buhringer, H.; Harms, V. Accumulation of cobalt during embryonic development of rainbow trout (Salmo gairdneri Rich). Aquaculture 1978, 13, 61-66. [CrossRef]

331. Eckhert, C.D.; Rowe, R.I. Embryonic dysplasia and adult retinal dystrophy in boron-deficient zebrafish. J. Trace Elem. Exp. Med. 1999, 12, 213-219. [CrossRef]

332. Eckhert, C.D. Boron stimulates embryonic trout growth. J. Nutr. 1998, 128, 2488-2493. [CrossRef] [PubMed]

333. Hunt, C.D. Dietary boron: Progress in establishing essential roles in human physiology. J. Trace Elem. Med. Biol. 2012, 26, 157-160. [CrossRef]

334. Nielsen, F.H. Update on human health effects of boron. J. Trace Elem. Med. Biol. 2014, 28, 383-387. [CrossRef] [PubMed]

335. Miller, E.P.; Wu, Y.; Carrano, C.J. Boron uptake, localization, and speciation in marine brown algae. Metallomics 2016, 8, 161-169.

336. Verbost, P.M.; Rooij, J.; Flik, G.; Lock, R.A.C.; Wendelaar Bonga, S.E. The movement of cadmium through freshwater trout branchial epithelium and its interference with calcium transport. J. Exp. Biol. 1989, 145, 185-197. [CrossRef]

337. Adamse, P.; Van der Fels-Klerx, H.J.I.; de Jong, J. Cadmium, lead, mercury and arsenic in animal feed and feed materials-Trend analysis of monitoring results. Food Addit. Contam. Part A 2017, 34, 1298-1311. [CrossRef]

338. Francesconi, K.; Kuehnelt, D. Arsenic Compounds in the Environment. In Environmental Chemistry of Arsenic; Frankenberger, J., Ed.; Marcel Dekker Inc.: New York, NY, USA, 2002; pp. 51-94.

339. Ackley, K.; Bhymer, C.; Sutton, K.; Caruso, J. Speciation of arsenic in fish tissue using microwave-assisted extraction followed by HPLC-ICP-MS. J. Anal. Atom. Spectrom. 1999, 14, 845-885. [CrossRef]

340. Camurati, J.R.; Salomone, V.N. Arsenic in edible macroalgae: An integrated approach. J. Toxicol. Environ. Health Part B 2019, 23, 1-12. [CrossRef] [PubMed]

341. Sele, V.; Sloth, J.J.; Lundebye, A.-K.; Larsen, E.H.; Berntssen, M.H.G.; Amlund, H. Arsenolipìds in marine oils and fats: A review of occurrence, chemistry and future research needs. Food Chem. 2012, 133, 618-630. [CrossRef]

342. Cockell, K.A.; Hilton, J.W.; Bettger, W.J. Chronic toxicity of dietary disodium arsenate heptahydrate to juvenile rainbow trout (Oncorhynchus mykiss). Arch. Environ. Contam. Toxicol 1991, 21, 518-527. [CrossRef] [PubMed]

343. Erickson, R.J.; Mount, D.R.; Highland, T.L.; Russell Hockett, J.; Jenson, C.T. The relative importance of waterborne and dietborne arsenic exposure on survival and growth of juvenile rainbow trout. Aquat. Toxicol 2011, 104, 108-115. [CrossRef]

344. Sloth, J.J.; Julshamn, K.; Lundebye, A.K. Total arsenic and inorganic arsenic content in Norwegian fish feed products. Aquac. Nutr. 2005, 11, 61-66. [CrossRef]

345. Biancarosa, I.; Sele, V.; Belghit, I.; Ørnsrud, R.; Lock, E.-J.; Amlund, H. Replacing fish meal with insect meal in the diet of Atlantic salmon (Salmo salar) does not impact the amount of contaminants in the feed and it lowers accumulation of arsenic in the fillet. Food Addit. Contam. Part A 2019, 36, 1191-1205. [CrossRef]

346. Zimmer, A.M.; Brix, K.V.; Wood, C.M. Mechanisms of $\mathrm{Ca}^{2+}$ uptake in freshwater and seawater-acclimated killifish, Fundulus heteroclitus, and their response to acute salinity transfer. J. Comp. Physiol. B 2019, 189, 47-60.

347. Persson, P.; Sundell, K.; Björnsson, B.T.; Lundqvist, H. Calcium metabolism and osmoregulation during sexual maturation of river running Atlantic salmon. J. Fish Biol. 1998, 52, 334-349. [CrossRef]

348. Kwon, H.; Hayashi, S.; Mugiya, Y. Vitellogenin induction by estradiol-17 $\beta$ in primary hepatocyte culture in the rainbow trout, Oncorhynchus mykiss. Comp. Biochem. Physiol. Part B Comp. Biochem. 1993, 104, 381-386. [CrossRef]

349. Flik, G.; Verbost, P.M.; Bonga, S.E.W. Calcium transport processes in fishes. Fish Physiol. 1995, 12, 317-342.

350. Lin, C.H.; Hwang, P.P. The control of calcium metabolism in zebrafish (Danio rerio). Int. J. Mol. Sci. 2016, 17, 1783. [CrossRef] [PubMed]

351. Marshall, W.S.N. $\mathrm{Cl}^{-}, \mathrm{Ca}^{2+}$, and $\mathrm{Zn}^{2+}$ transport by fish gills: Retrospective review and prospective synthesis. J. Exp. Zool. 2002, 293, 264-283. [CrossRef]

352. Sundell, K.; Bishop, J.E.; Bjornsson, B.T.; Norman, A.W. 1,25-Dihydroxyvitamin-D ${ }_{3}$ in the Atlantic cod-plasma-levels, a plasma binding component, and organ distribution of a high affinity receptor. Endocrinology 1992, 131, 2279-2286. [CrossRef]

353. Graff, I.E.; Aksnes, L.; Lie, O. In vitro hydroxylation of vitamin $\mathrm{D}_{3}$ and 25-hydroxy vitamin $\mathrm{D}_{3}$ in tissues of Atlantic salmon Salmo salar, Atlantic mackerel Scomber scombrus, Atlantic halibut Hippoglossus hippoglossus and Atlantic cod Gadus morhua. Aquac. Nutr. 1999, 5, 23-32. [CrossRef]

354. Fraser, D.R. Evolutionary biology: Mysteries of vitamin D in fish. In Vitamin D (Fourth Edition) Volume 1: Biochemistry, Physiology and Diagnostics; Feldman, D., Pike, J.W., Bouillon, R., Giovannucci, E., Hewison, M., Eds.; Academic Press: San Diego, CA, USA, 2018; Volume 1, pp. 13-27.

355. Coloso, R.; King, K.; Fletcher, J.W.; Hendrix, H.A.; Subrmanyam, M.; Weiss, P.; Ferraris, R.A. Phosphorus utilization in rainbow trout (Oncorhynchus mykiss) fed practical diets and its consequences on effluent phosphorus levels. Aquaculture 2003, 220, 801-820. [CrossRef]

356. Hernando, N.; Wagner, C.A. Mechanisms and regulation of intestinal phosphate absorption. Compreh. Physiol. 2018, 8, 1065-1090. 
357. Wagner, G.F. Stanniocalcin: Structure, function, and regulation. In The Biochemistry and Molecular Biology of Fishes; Hochachka, P.W., Mommsen, T.P., Eds.; Elsevier Science: Amsterdam, The Netherlands, 1993; pp. 419-434.

358. Wagner, G.F.; Jaworski, E.M.; Haddad, M. Stanniocalcin in the seawater salmon: Structure, function, and regulation. Am. J. Physiol. 1998, 274, 117-118. [CrossRef]

359. Potts, J.T. Parathyroid hormone: Past and present. J. Endocrinol. 2005, 187, 311-325. [CrossRef]

360. Guerreiro, P.M.; Renfro, J.L.; Power, D.M.; Canario, A.V. The parathyroid hormone family of peptides: Structure, tissue distribution, regulation, and potential functional roles in calcium and phosphate balance in fish. Am. J. Physiol. Regul. Integr. Comp. Physiol. 2007, 292, 679-696. [CrossRef] [PubMed]

361. Wendalaar Bonga, S.E.; Flik, G. Calcium regulation in fish. In Aquaculture: Fundamental and Applied Research; Lahlou, B., Vitiello, P., Eds.; American Geophysical Union: Washington, DC, USA, 1995; pp. 47-59.

362. Fenwick, J.C.; Vermette, M.G. Vitamin $\mathrm{D}_{3}$ and the renal handling of phosphate in American eels. Fish Physiol. Biochem. 1989, 177, 351-358. [CrossRef]

363. Vielma, J.; Lall, S.; Koskela, J.; Mattila, P. Influence of low dietary cholecalciferol intake on phosphorus and trace element metabolism by rainbow trout (Oncorhynchus mykiss, Walbaum). Comp. Biochem. Physiol. Mol. Integr. Physiol. 1999, 122B, 117-125. [CrossRef]

364. Fjelldal, P.G.; Lock, E.J.; Hansen, T.J.; Waagbø, R.; Wargelius, A.; Martens, L.G.; El-Mowafi, A.; Ørnsrud, R. Continous light induces bone resorption and affects vertebral morphology in Atlantic salmon (Salmo salar L.) fed a phosphorous deficient diet. Aquac. Nutr. 2012, 18, 610-619. [CrossRef]

365. Hossain, M.A.; Yoshimatsu, T. Dietary calcium requirements of fishes. Aquac. Nutr. 2014, 20, 1-11. [CrossRef]

366. Nakamura, Y.; Yamada, J. Effects of dietary calcium levels. Ca/P ratios, and calcium components on calcium absorption rate in carp. Bull. Fac. Fish. Hokkaido Univ. 1980, 31, 277-282.

367. Ogino, C.; Takeda, H. Mineral requirements in fish. 3. Calcium and phosphorus requirements of carp. Bull. Jpn. Soc. Sci. Fish. 1976, 42, 793-799. [CrossRef]

368. Robinson, E.; Rawles, S.D.; Yette, H.E.; Greene, L.W. An estimate of the dietary calcium requirement of fingerling Tilapia aurea reared in calcium-free water. Aquaculture 1984, 41, 389-393. [CrossRef]

369. Sakamoto, S.; Yone, Y. Effect of dietary calcium/phosphorus ratio upon growth, feed efficiency and blood serum Ca and P level in red sea bream. Bull. Jpn. Soc. Sci. Fish. 1973, 39, 343-348. [CrossRef]

370. Lovell, R.T. Dietary phosphorus requirement of channel catfish (Ictalurus punctatus). Trans. Am. Fish. Soc. 1978, 107, 617-621. [CrossRef]

371. Dougall, D.S.; Woods, L.C.; Douglass, L.W.; Soares, J.H. Dietary phosphorus requirement of juvenile striped bass Morone saxatilis. J. World Aquac. Soc. 1996, 27, 82-91. [CrossRef]

372. Robinson, E.; Rawles, S.D.; Yette, H.E.; Greene, L.W. Dietary calcium requirement of channel catfish (Ictalurus punctatus), reared in calcium-free water. Aquaculture 1986, 53, 263-270. [CrossRef]

373. Robinson, E.H.; LaBomascus, D.; Brown, P.B.; Linton, T.L. Dietary calcium and phosphorus requirements of Oreochromis aureus reared in calcium-free water. Aquaculture 1987, 64, 267-276. [CrossRef]

374. Åsgård, T.; Shearer, K.D. Dietary phosphorus requirement of juvenile Atlantic salmon, Salmo salar L. Aquac. Nutr. 1997, 3, 17-23. [CrossRef]

375. Ketola, H.G. Requirement of Atlantic salmon for dietary phosphorus. Trans. Am. Fish. Soc. 1975, 104, 548-551. [CrossRef]

376. Vielma, J.; Lall, S.P. Phosphorus utilization by Atlantic salmon (Salmo salar) reared in freshwater is not influenced by higher dietary calcium intake. Aquaculture 1998, 160, 117-128. [CrossRef]

377. Rodehutscord, M. Response of rainbow trout (Oncorhynchus mykiss) growing from 50 to $200 \mathrm{~g}$ to supplements of dibasic sodium phosphate in a semipurified diet. J. Nutr. 1996, 126, 324-331. [CrossRef] [PubMed]

378. Ketola, H.G.; Richmond, M.E. Requirement of rainbow trout for dietary phosphorus and its relationship to the amount discharged in hatchery effluents. Trans. Am. Fish. Soc. 1994, 123, 587-594. [CrossRef]

379. Watanabe, T.; Murakami, A.; Takeuchi, L.; Nose, T.; Ogino, C. Mineral requirements in fish 9. Requirement of chum salmon held in fresh-water for dietary phosphorus. Bull. Jpn. Soc. Sci. Fish. 1980, 46, 361-367. [CrossRef]

380. Andrews, J.W.; Murai, T.; Campbell, C. Effects of dietary calcium and phosphorus on growth, food conversion, bone ash and hematocrit levels of catfish. J. Nutr. 1973, 103, 766-771. [CrossRef] [PubMed]

381. Wilson, R.P.; Robinson, E.H.; Gatlin, D.M., III; Poe, W.E. Dietary phosphorus requirement of channel catfish. J. Nutr. 1988, 112, 1197-1202. [CrossRef] [PubMed]

382. Borlongan, I.; Satoh, S. Dietary phosphorus requirement of juvenile milkfish, Chanos chanos Forsskal. Aquac. Res. 2001, 32, 26-32. [CrossRef]

383. Carvalho, P.L.P.F.; Koch, J.F.A.; Cintra, F.T.; Fernandes, A.C., Jr.; Sartori, M.M.P.; Barros, M.; Padihla, P.D.; Pezzato, L.L. Available phosphorus as a reproductive performance enhancer for female Nile tilapia. Aquaculture 2018, 486, 202-209. [CrossRef]

384. Yao, Y.F.; Jiang, M.; Wen, H.; Wu, F.; Liu, W.; Tian, J.; Yang, C.G. Dietary phosphorus requirement of GIFT strain of Nile tilapia Oreochromis niloticus reared in fresh water. Aquac. Nutr. 2014, 20, 273-280. [CrossRef]

385. Xie, D.; Han, D.; Zhu, X.; Yang, Y.; Jin, J.; Liu, H.; Xie, S. Dietary available phosphorus requirement for on-growing gibel carp (Carassius auratus gibelio var CAS III). Aquac. Nutr. 2017, 23, 1104-1112. [CrossRef] 
386. Liang, J.J.; Liu, Y.J.; Tian, L.X.; Yang, H.J.; Liang, G.Y. Dietary available phosphorus requirement of juvenile grass carp (Ctenopharyngodon idella). Aquac. Nutr. 2012, 18, 181-188. [CrossRef]

387. Sun, Y.; Li, B.; Zhang, X.; Chen, M.; Tang, H.; Yu, X. Dietary available phosphorus requirement of crucian carp, Carassius auratus. Aquac. Nutr. 2018, 24, 1494-1501. [CrossRef]

388. Nwanna, L.C.; Adebayo, I.A.; Omitoyin, B.O. Phosphorus requirements of African catfish, Clarias gariepinus, based on broken-line regression analysis methods. ScienceAsia 2009, 35, 227-233. [CrossRef]

389. Yu, H.R.; Zhang, Q.; Xiong, D.M.; Huang, G.Q.; Li, W.Z.; Liu, S.W. Dietary available phosphorus requirement of juvenile walking catfish. Clarias Leather. Aquac. Nutr. 2012, 19, 483-490. [CrossRef]

390. Yuan, Y.C.; Yang, H.J.; Gong, S.Y.; Luo, Z.; Yu, D.H.; Yan, J.L.; Yang, X.F. Dietary phosphorus requirement of juvenile Chinese sucker Myxocyprinus asiaticus. Aquac. Nutr. 2011, 17, 159-169. [CrossRef]

391. Brown, M.L.; Jaramillo, F., Jr.; Gatlin, D.M., III. Dietary phosphorus requirement of juvenile sunshine bass, Morone chrysops $\times$ M. saxatilis. Aquaculture 1993, 113, 355-363. [CrossRef]

392. Shen, H.M.; Chen, X.R.; Chen, W.Y.; Lin, S.M.; Chen, Y.J.; Zhang, L.; Luo, L. Influence of dietary phosphorus levels on growth, body composition, metabolic response and antioxidant capacity of juvenile snakehead (Channa argus $\times$ Channa maculata). Aquac. Nutr. 2016, 23, 662-670. [CrossRef]

393. Araújo, J.G.; Guimarães, I.G.; Mota, C.S.; Paula, F.G.; Café, M.B.; Pádua, D.M.C. Dietary available phosphorus requirement for tambaqui, Colossoma macropomum, juveniles based on growth, haematology and bone mineralization. Aquac. Nutr. 2016, 23, 822-832. [CrossRef]

394. Davis, D.A.; Robinson, E.H. Dietary phosphorus requirement of juvenile red drum Sciaenops ocellatus. J. World Aquac. Soc. 1987, 18, 129-136. [CrossRef]

395. Sakamoto, S.; Yone, Y. Effect of dietary phosphorus level on chemical composition of red sea bream. Bull. Jpn. Soc. Sci. Fish. 1978, 44, 227-229. [CrossRef]

396. Pimentel Rodrigues, A.; Oliva Teles, A. Phosphorus requirements of gilthead sea bream (Sparus aurata L.) juveniles. Aquac. Res. 2001, 32, 15-161. [CrossRef]

397. Shao, Q.; Ma, J.; Xu, Z.; Hu, W.; Xu, J.; Xie, S. Dietary phosphorus requirement of juvenile black seabream, Sparus macrocephalus. Aquaculture 2008, 277, 92-100. [CrossRef]

398. Roy, P.K.; Lall, S.P. Dietary phosphorus requirement of juvenile haddock (Melanogrammus aeglefinus L). Aquaculture 2003, 221, 451-468. [CrossRef]

399. Zhang, C.; Mai, K.; Ai, Q.; Zhang, W.; Duan, Q.; Tan, B.; Ma, H.; Xu, W.; Linfu, Z.; Wang, X. Dietary phosphorus requirement of juvenile Japanese seabass, Lateolabrax japonicus. Aquaculture 2006, 255, 201-209. [CrossRef]

400. Olivia-Teles, A.; Pimentel-Rodrigues, A. Phosphorus requirement of European sea bass (Dicentrarchus labrax L.) juveniles. Aquac. Res. 2004, 35, 636-642. [CrossRef]

401. Ye, C.X.; Liu, Y.J.; Tian, L.X.; Mai, K.S.; Du, Z.Y.; Yang, H.J.; Niu, J. Effect of dietary calcium and phosphorus on growth, feed efficiency, mineral content and body composition of juvenile grouper, Epinephelus coioides. Aquaculture 2006, 255, 263-271. [CrossRef]

402. Mai, K.; Zhang, C.; Ai, Q.; Duan, Q.; Xu, W.; Zhang, L.; Liufu, Z.; Tan, B. Dietary phosphorus requirement of large yellow croaker, Pseudosciaena crocea R. Aquaculture 2006, 251, 346-353. [CrossRef]

403. Choi, S.M.; Kim, K.W.; Kang, Y.J.; Wang, X.J.; Kim, J.W.; Yoo, G.Y.; Bai, S.C. Re-evaluation of the phosphorus requirement of juvenile olive flounder Paralichthys olivaceus and the bioavailability of various inorganic phosphorus sources. J. World Aquac. Soc. 2005, 36, 217-222. [CrossRef]

404. Uyan, O.; Koshio, S.; Ishikawa, M.; Uyan, S.; Ren, T.; Yokoyama, S.; Komilus, F.C.; Michael, F.R. Effects of dietary phosphorus and phospholipid level on growth, and phosphorus deficiency signs in juvenile Japanese flounder, Paralichthys olivaceus. Aquaculture 2007, 267, 44-54. [CrossRef]

405. Wang, X.J.; Choi, S.; Park, S.; Yoo, G.; Kim, K.; Kang, J.C.; Bai, S.C. Optimum dietary phosphorus level of juvenile Japanese flounder Paralichthys olivaceus reared in the recirculating system. Fish. Sci. 2005, 71, 168-173. [CrossRef]

406. Antony Jesu Prabhu, P.; Schrama, J.W.; Kaushik, S.J. Quantifying the dietary phosphorus requirement of fish-A meta-analytic approach. Aquac. Nutr. 2013, 19, 243-249. [CrossRef]

407. National-Research-Council, N. Nutrient Requirements of Swine; The National Academies Press: Washington, DC, USA, 2012.

408. Skonberg, D.I.; Yogev, L.; Hardy, R.W.; Dong, F.M. Metabolic response to dietary phosphorus intake in rainbow trout (Oncorhynchus mykiss). Aquaculture 1997, 157, 11-24. [CrossRef]

409. Sugiura, S.H.; Hardy, R.W.; Roberts, R.J. The pathology of phosphorus deficiency in fish-A review. J. Fish. Dis 2004, 27, 255-265. [CrossRef] [PubMed]

410. Lall, S.P.; Lewis-McCrea, L.M. Role of nutrients in skeletal metabolism and pathology in fish-An overview. Aquaculture 2007, 267, 3-19. [CrossRef]

411. Baeverfjord, G.; Antony Jesu Prabhu, P.; Fjelldal, P.G.; Albrektsen, S.; Hatlen, B.; Denstadli, V.; Waagbø, R. Mineral nutrition and bone health in salmonids. Rev. Aquac. 2019, 11, 740-765. [CrossRef]

412. Drábiková, L.; Fjelldal, P.G.; De Clercq, A.M.N.; Morken, T.; McGurk, C.; Witten, P.E. Vertebral column adaptations in juvenile Atlantic salmon Salmo salar, L. as a response to dietary phosphorus. Aquaculture 2021, 541, 736776. [CrossRef] 
413. Fjelldal, P.G.; Hansen, T.; Breck, O.; Ørnsrud, R.; Lock, E.J.; Waagbø, R.; Wargelius, A.; Eckhard Witten, P. Vertebral deformities in farmed Atlantic salmon (Salmo salar L.) - etiology and pathology. J. Appl. Ichthyol. 2012, 28, 433-440. [CrossRef]

414. Witten, P.E.; Fjelldal, P.G.; Huysseune, A.; McGurk, C.; Obach, A.; Owen, M.A.G. Bone without minerals and its secondary mineralization in Atlantic salmon (Salmo salar): The recovery from phosphorus deficiency. J. Exp. Biol. 2019, $222,188763$. [CrossRef]

415. Witten, P.E.; Owen, M.A.; Fontanillas, R.; Soenens, M.; McGurk, C.; Obach, A. A primary phosphorus-deficient skeletal phenotype in juvenile Atlantic salmon Salmo salar: The uncoupling of bone formation and mineralization. J. Fish Biol. 2016, 88, 690-708. [CrossRef] [PubMed]

416. Lall, S.P. Digestibility, metabolism and excretion of dietary phosphorous in fish. In Nutritional Strategies and Aquaculture Waste; Cowey, C.B., Cho, C.Y., Eds.; University of Guelph: Guelph, ON, Canada, 1991; pp. 21-36.

417. Cheryan, M.; Rackis, J.J. Phytic acid interactions in food systems. Crit. Rev. Food Sci. 1980, 13, 297-335. [CrossRef] [PubMed]

418. Cao, L.; Wang, W.; Yang, C.; Yang, Y.; Diana, J.; Yakupitiyage, A.; Luo, Z.; Li, D. Review: Application of microbial phytase in fish feed. Enzym. Microb. Technol. 2007, 40, 497-507. [CrossRef]

419. Dersjant-Li, Y.; Awati, A.; Schulze, H.; Partridge, G. Phytase in non-ruminant animal nutrition: A critical review on phytase activities in the gastrointestinal tract and influencing factors. J. Sci. Food Agric. 2015, 95, 878-896. [CrossRef]

420. Lemos, D.E.L.; Tacon, A.G.J. Use of phytases in fish and shrimp feeds: A review. Rev. Aquac. 2017, 9, 266-282. [CrossRef]

421. Vohra, A.; Satanarayana, T. Phytases: Microbial sources, production, purification, and potential biotechnological applications. Crit. Rev. Biotech. 2003, 23, 29-60. [CrossRef]

422. Verlhac-Trichet, V.; Vielma, J.; Dias, J.; Rema, P.; Santigosa, E.; Wahli, T.; Vogl, K. The efficacy of a novel microbial 6-phytase expressed in Aspergillus oryzae on the performance and phosphorus utilization of cold- and warm-water fish: Rainbow trout, Oncorhynchus mykiss, and Nile tilapia, Oreochromis niloticus. J. World Aquac. Soc. 2014, 45, 367-379. [CrossRef]

423. Albrektsen, S.; Lock, E.J.; Bæverfjord, G.; Pedersen, M.; Krasnov, A.; Takle, H.; Veiseth-Kent, E.; Ørnsrud, R.; Waagbø, R.; Ytteborg, E. Utilization of $\mathrm{H}_{2} \mathrm{SO}_{4}$-hydrolysed phosphorus from herring bone byproducts in feed for Atlantic salmon (Salmo salar) $0+$ postsmolt. Aquac. Nutr. 2017, 24, 348-365. [CrossRef]

424. Ogino, C.; Takeuchi, L.; Takeda, H.; Watanabe, T. Availability of dietary phosphorus in carp and rainbow trout. Bull. Jpn. Soc. Sci. Fish. 1979, 45, 1527-1532. [CrossRef]

425. Watanabe, K.; Satoh, S.; Takeuchi, T. Availability of minerals in fish meal. Asian Fish. Soc. 1988, 1, $175-195$.

426. Köprücü, K.; Özdemir, Y. Apparent digestibility of selected feed ingredients for Nile tilapia (Oreochromis niloticus). Aquaculture 2005, 250, 308-316. [CrossRef]

427. Houston, A.H. Erythrocytic magnesium in freshwater fishes. Magnesium 1985, 4, 106-128. [PubMed]

428. Bijvelds, M.; Velden, J.; Kolar, Z.I.; Flik, G. Magnesium transport in freshwater teleosts. J. Exp. Biol. 1998, 201, 1981-1990. [CrossRef] [PubMed]

429. Cowey, C.B.; Knox, D.; Adron, J.W.; George, S.; Pirie, B. The production of renal calcinosis by magnesium deficiency in rainbow trout (Salmo gairdneri). Br. J. Nutr. 1977, 38, 127-135. [CrossRef]

430. Shearer, K.D.; Åsgård, T. The effect of water-borne magnesium on the dietary magnesium requirement of rainbow trout (Oncorhynchus mykiss). Fish Physiol. Biochem. 1992, 9, 387-392. [CrossRef]

431. Dabrowska, H.; Meyer-Burgdorff, K.; Gunther, K.D. Magnesium status in freshwater fish, common carp (Cyprinus carpio, L.) and the dietary protein-magnesium interaction. Fish Physiol. Biochem. 1991, 9, 165-172. [CrossRef]

432. Oikari, A.O.J.; Rankin, J.C. Renal excretion of magnesium in a freshwater teleost, Salmo gairdneri. J. Exp. Biol. 1985, 117, 319-333. [CrossRef]

433. Hickman, C.P.; Trump, B.F. The Kidney; Academic Press: New York, NY, USA, 1969; Volume 1, pp. 91-239.

434. El-Zibdeh, M.; Ide, K.; Furuichi, M. Effects of the deletion of mg or fe from semi purified diets on growth and efficiency of feed utilization of Yellow croaker Nibea albiflora. J. Fac. Agric. Kyushu Univ. 1996, 40, 391-397. [CrossRef]

435. Sakamoto, S.; Yone, Y. Requirement of red sea bream for dietary Mg. Bull. Jpn. Soc. Fish. 1979, 45, 57-60. [CrossRef]

436. Ogino, C.; Takashima, F.; Chiou, J.Y. Requirement of rainbow trout for dietary magnesium. Bull. Jpn. Soc. Sci. Fish. 1978, 44, 1105-1108. [CrossRef]

437. Van Der Velden, J.A.; Kolar, Z.I.; Flik, G. Intake of magnesium from water by freshwater tilapia fed on a low-Mg diet. Comp. Biochem. Physiol. 1991, 99A, 103-105. [CrossRef]

438. Dabrowska, H.; Meyer-Burgdorff, K.; Gunther, K.D. Interaction between dietary protein and magnesium level in tilapia (Oreochromis niloticus). Aquaculture 1989, 76, 277-291. [CrossRef] 